\author{
UNIVERSIDADE DE BRASÍLIA \\ INSTITUTO DE CIÊNCIA POLÍTICA \\ PROGRAMA DE PÓS-GRADUAÇÃO EM CIÊNCIA POLÍTICA
}

ADRYELLE PEDROSA FONTES

PARTICIPAÇÃO DO LEGISLATIVO NA DEFINIÇÃO DAS POLÍTICAS TRABALHISTAS E SINDICAIS 
UNIVERSIDADE DE BRASÍLIA

INSTITUTO DE CIÊNCIA POLÍTICA

PROGRAMA DE PÓS-GRADUAÇÃO EM CIÊNCIA POLÍTICA

\author{
ADRYELLE PEDROSA FONTES
}

\title{
PARTICIPAÇÃO DO LEGISLATIVO NA DEFINIÇÃO DAS POLÍTICAS TRABALHISTAS E SINDICAIS
}

Professor Orientador: Denilson

Bandeira Coêlho

Dissertação apresentada ao Instituto de Ciência Política da Universidade de Brasília como parte dos requisitos para a obtenção do grau de Mestre em Ciência Política.

Área de Concentração: Política e Instituições.

Brasília 
UNIVERSIDADE DE BRASÍLIA

INSTITUTO DE CIÊNCIA POLÍTICA

PROGRAMA DE PÓS-GRADUAÇÃO EM CIÊNCIA POLÍTICA

\section{PARTICIPAÇÃO DO LEGISLATIVO NA DEFINIÇÃO DAS POLÍTICAS TRABALHISTAS E SINDICAIS}

ADRYELLE PEDROSA FONTES

Banca Examinadora:

Prof. Dr. Denilson Bandeira Coêlho - IPol/UnB

Prof. Dr. André Borges de Carvalho- IPol/UnB

Prof. Dr. Wladimir Gramacho - Faculdade de Comunicação / UnB

Prof. Dr. Mathieu Turgeon - IPol/UnB (Suplente) 


\section{AGRADECIMENTOS}

Ofereço meus agradecimentos aos meus pais, por, conscientemente ou não, me despertarem o gosto pela política e pelos estudos. Especialmente, a minha mãe, Fernanda Pedrosa, pelo exemplo que sempre foi para mim e pelos sacrifícios que realizou para que meus irmãos e eu pudéssemos chegar aos lugares que chegamos.

Ao meu professor e orientador, Denilson Coêlho, não apenas pela tutoria, críticas e indicações sempre pertinentes, mas também pelo apoio em momentos decisivos nesse processo.

Aos membros da banca de qualificação, professores André Borges e Suely Guimarães, pelas valiosas sugestões e considerações.

Aos professores do Instituto de Ciência Política da Universidade de Brasília, que contribuíram para a minha formação.

À Coordenação de Relacionamento, Pesquisa e Informação da Câmara dos Deputados, pelo acesso a dados detalhados de tramitação de proposições.

Por fim, ao meu marido, Fernando Moura, pelo incentivo e paciência. 


\section{RESUMO}

Análises sobre o papel do Legislativo brasileiro na conformação das políticas públicas normalmente assumem que esse Poder é marginal em relação ao Executivo, funcionando como mero endossador das decisões e propostas deste. Muitos estudos também salientam que o Legislativo está voltado para a formulação e aprovação de uma agenda de políticas que distribui benefícios aos seus redutos eleitorais em vez de políticas que mirem o interesse público mais amplo. Contudo, um olhar mais apurado sobre a relação ExecutivoLegislativo no Brasil parece apontar para a existência de parlamentares mais ativos durante a formulação de políticas e menos orientados a questões paroquiais. Este trabalho procura identificar qual é a contribuição do Legislativo no processo de elaboração de políticas públicas, a partir da análise de um tipo de política social específico, qual seja: políticas trabalhistas e sindicais. O propósito é identificar se os deputados federais brasileiros desempenham papel ativo ou marginal na formulação desse tipo de política, bem como se são guiados por uma lógica paroquial ou mais universal.

Palavras-chave: Legislativo, Executivo, políticas públicas, trabalho. 


\begin{abstract}
Analysis on the role of the Brazilian legislature in the policymaking process often argue that the Congress just "rubber stamp" Executive decisions and initiatives. They also point out that congressman's bills are predominantly linked to particularistic or local interests, having no broader or national impact. However, a closer examination of ExecutiveLegislative relations in Brazil shows a more active and not parochial-oriented legislature. This paper evaluates the contribution of the legislature in the public policy process through the analysis of a specific type of social policy: labor and union policies. The purpose is to identify whether Brazilian representatives play an active or marginal role in the formulation of such policy, and whether they are guided by a parochial or universal logic.
\end{abstract}

Keywords: legislature, Executive branch, public policy, labor policies. 


\section{LISTA DE QUADROS}

Quadro 1- Síntese das abordagens apresentadas sobre o comportamento dos deputados

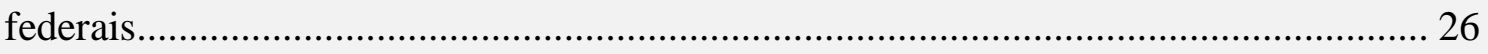

Quadro 2 - Situação da tramitação das proposições objeto da pesquisa ....................... 47

Quadro 3 - Distribuição dos projetos trabalhistas apresentados entre 2003 e 2014 pelos deputados federais, segundo a origem partidária (tamanho da bancada na eleição) ...... 57

Quadro 4 - Distribuição dos projetos trabalhistas apresentados entre 2003 e 2014 pelos deputados federais, conforme orientação ideológica do partido .................................... 58

Quadro 5 - Representação sindical x empresarial na Câmara dos Deputados .............. 60

Quadro 6 - Tipo de proposição, por origem (2003-2014) ............................................. 62

Quadro 7- Conteúdo dos projetos trabalhistas apresentados na Câmara dos Deputados (2003-2014)

Quadro 8- Distribuição dos temas dos projetos trabalhistas apresentados entre 2003 e 2014 pelos deputados federais, conforme orientação ideológica do partido

Quadro 9 - Distribuição temática dos projetos transformados em norma jurídica, por autoria (2003-2014) 


\section{LISTA DE GRÁFICOS}

Gráfico 1 - Total de projetos apresentados pelos deputados à Câmara dos Deputados $\mathrm{x}$ total de projetos de tema trabalhista apresentados pelos deputados (2003-2014) 53

Gráfico 2 - Distribuição dos projetos trabalhistas apresentados entre 2003 e 2014 pelos deputados federais, conforme a origem partidária......................................................... 56

Gráfico 3 - Total de projetos apresentados pelo Executivo x total de projetos de tema trabalhista apresentados pelo Executivo (2003-2014)...... 61 


\section{LISTA DE TABELAS}

Tabela 1-Situação dos projetos trabalhistas apresentados pelos deputados federais (20032014) 68

Tabela 2 - Situação dos projetos trabalhistas apresentados pelo Poder Executivo (20032014)

Tabela 3- Leis trabalhistas publicadas, por tipo de proposição originária, segundo o Poder de origem e o grau de alteração do texto original pelos deputados federais (2003-2014)

Tabela 4- Número de projetos e dispositivos por categoria 79

Tabela 5- - Nível de agregação das propostas apresentadas na Câmara dos Deputados (2003-2014) 85

Tabela 6- Nível de agregação das propostas transformadas em lei (2003-2014) 86 


\section{LISTA DE ABREVIATURAS E SIGLAS}

ADI - Ação Direta de Inconstitucionalidade

CAPADR - Comissão de Agricultura e Política Rural da Câmara dos Deputados

CD - Câmara dos Deputados

CCJC - Comissão de Constituição e Justiça da Câmara

CF - Constituição Federal

CGT - Confederação Geral dos Trabalhadores

CLT - Consolidação das Leis do Trabalho

CN - Congresso Nacional

CNA - Confederação Nacional da Agricultura

CNI - Confederação Nacional da Indústria

CTASP - Comissão de Trabalho, de Administração e Serviço Público

CUT - Central Única dos Trabalhadores

DEM - Democratas

DIAP - Departamento Intersindical de Assessoria Parlamentar

Febraban - Federação Brasileira de Bancos

Fiesp - Federação das Indústrias do Estado de São Paulo

FGTS - Fundo de Garantia do Tempo de Serviço

FHC - Fernando Henrique Cardoso

FNT - Fórum Nacional do Trabalho

MP - Medida Provisória

PEC - Projeto de Emenda Constitucional

PCdoB - Partido Comunista do Brasil

PDT - Partido Democrático Trabalhista

PFL - Partido da Frente Liberal

PL - Partido Liberal 
PL - Projeto de Lei ordinária

PLR - Participação nos lucros e resultados

PMDB - Partido do Movimento Democrático Brasileiro

PMN - Partido da Mobilização Nacional

PNBE - Pensamento Nacional das Bases Empresariais

PPS - Partido Popular Socialista

PR - Partido da República

PRB - Partido Republicano Brasileiro

PRONATEC - Programa Nacional de Acesso ao Ensino Técnico e Emprego

PROS - Partido Republicano da Ordem Social

PSB - Partido Socialista Brasileiro

PSC - Partido Social Cristão

PSD - Partido Social Democrático

PSDB - Partido da Social Democracia Brasileira

PSL - Partido Social Liberal

PSOL - Partido Socialismo e Liberdade

PT - Partido dos Trabalhadores

PTB - Partido Trabalhista Brasileiro

PTdoB - Partido Trabalhista do Brasil

PV - Partido Verde

SF - Senado Federal 
1 - INTRODUÇÃO ............................................................................................... 13

2 - PRESSUPOSTOS TEÓRICOS SOBRE A INTERAÇÃo ENTRE O LEGISLATIVO E O EXECUTIVO NO BRASIL .................................................... 20

2.1 - Legislativo como ator relevante na formulação das políticas............................. 26

2.2 - Legislativo voltado para a produção de políticas de impacto amplo .................. 29

3 - OS DEBATES SOBRE AS QUESTÕES TRABALHISTAS E SINDICAIS NO

BRASIL............................................................................................................................... 33

4 - ASPECTOS METODOLÓGICOS ...................................................................... 45

4.1 - Classificação das políticas públicas .................................................................. 48

5 - A TESE DO LEGISLATIVO COMO ATOR MARGINAL SOB EXAME ..... 53

5.1 - Projetos apresentados: alta proposição pelo Legislativo ………………………. 53

5.2 - Projetos rejeitados e "engavetados": o bloqueio às propostas do Executivo.... 67

5.3 - Projetos convertidos em lei e vetados: interferência do Legislativo e a negociação

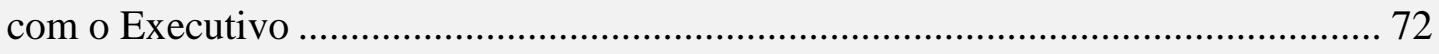

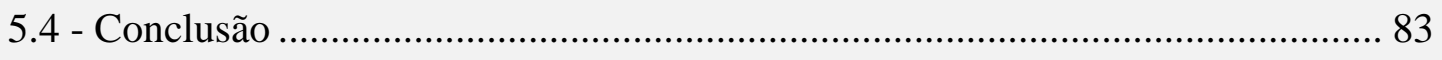

6 - A TESE DO LEgislativo COMO ATOR ORIENTAdo PARA PRODUÇÃO DE POLÍTICAS PAROQUIAIS SOB EXAME ............................... 85

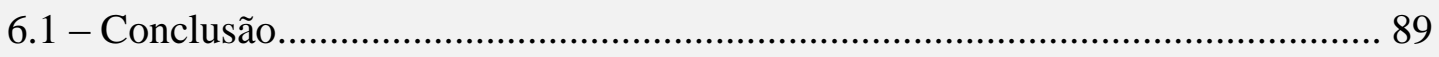

7 - CONSIDERAÇÕES FINAIS....................................................................................... 91

ANEXO I .................................................................................................................................. 94

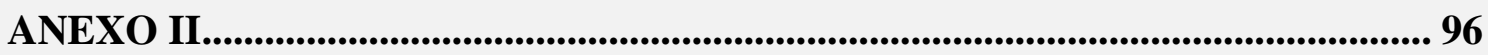

ANEXO III ..................................................................................................................................... 97

REFERÊNCIA BIBLIOGRÁFICA ..................................................................... 98 


\section{1 - INTRODUÇÃO}

Qual a participação do Poder Legislativo na definição dos contornos das políticas públicas? Para responder essa questão é necessário considerar, no Brasil, os padrões de interação entre o Poder Executivo e o Legislativo federais na produção das leis, já que ambos possuem competência para elaborar o componente normativo das políticas no nível federal ${ }^{1}$. Sobre as relações entre o Executivo e o Legislativo durante o processo legiferante, as análises mais influentes (FIGUEIREDO e LIMONGI, 1999; PEREIRA e MULLER, 2000; SANTOS, 1997) com frequência apontam o Poder Executivo como ator central e dominante, relegando ao Legislativo um papel marginal de mero endossador das iniciativas e decisões do Executivo.

Conforme essas pesquisas, a capacidade do Legislativo de moldar as políticas públicas de acordo com seus interesses é limitada em razão dos poderes desproporcionais do Poder Executivo vis-à-vis o Legislativo. As prerrogativas legislativas do Presidente da República, garantidas pela Constituição de 1988 (edição de Medidas Provisórias, com força de lei e vigência imediata, controle da execução do Orçamento Público, solicitação de urgência constitucional para matérias de sua autoria, o poder de iniciativa em quase todas as matérias; o poder de iniciativa exclusiva em determinadas matérias; e o poder de veto, etc.), permitem ao Executivo moldar o comportamento dos parlamentares, ocupar estrategicamente a agenda de votações e pôr em prática as políticas para as quais o Presidente foi eleito.

Segundo essa perspectiva, ainda, o Executivo também se favorece das regras de funcionamento do Congresso, que centralizam o poder decisório nas mãos dos líderes partidários. As prerrogativas previstas (nomeação e destituição dos parlamentares que irão compor as Comissões Temáticas, nomeação dos relatores dos projetos, inclusão e a retirada de projetos de pauta, concentração de deliberações sobre temas substantivos no Colégio de Líderes, etc.), de maneira geral, compelem os parlamentares a serem leais e a seguirem com certa regularidade as orientações dos líderes nas votações nominais em Plenário. O Executivo tem, assim, reduzidos os custos de negociação para aprovação de suas matérias, visto não ter de negociar com cada parlamentar individualmente, mas apenas com seus líderes.

\footnotetext{
${ }^{1}$ Isso exclui da análise o Poder Judiciário, apesar do reconhecimento de sua influência sobre o comportamento dos demais Poderes na produção e implementação de políticas públicas e até de seu poder normativo, por meio de súmulas e enunciados, por exemplo.
} 
Em razão desse contexto, o Executivo é tido como ator central do processo legislativo e como fonte predominante dos projetos aprovados e convertidos em lei. A evidência mais eloquente do controle de agenda dos trabalhos legislativos por parte do Executivo foi identificada por Figueiredo e Limongi (2004: 53), quando apontaram para o fato de que $86 \%$ das leis aprovadas entre 1989 e 2001 tiveram por origem aquele Poder. Existem, assim, poucas chances de proposta legislativa iniciada por um parlamentar de se transformar em norma jurídica. Coopera com este fato, ainda, a própria dinâmica do processo legislativo, com prazos legislativos raramente cumpridos, diversas proposições condenadas ao arquivamento ao final da legislatura, em conformidade com o artigo 105 do Regimento Interno da Câmara, outras tantas declaradas prejudicadas ou retiradas pelo próprio autor, etc.

Quando capazes de interferir na produção legal, os parlamentares seriam guiados por estratégias individualistas e eleitoreiras (AMES, 2001; MAINWARING, 1999). Para Ames (2001) e Mainwaring (1999), o sistema proporcional de lista aberta para seleção dos deputados federais brasileiros beneficia o voto pessoal em detrimento do partidário, conformando atitudes parlamentares individualistas e auto interessadas, dentre as quais destaca-se a adoção de políticas do tipo "pork barrel"2 em favor do seu eleitorado pessoal e de seus interesses privados, a expensas de políticas nacionais e da provisão de bens públicos (AMES, 2001:185-186). Nessa perspectiva, o Legislativo não é visto como uma instituição adequada para propor soluções para grandes questões sociais ou econômicas do país.

Levando-se em consideração as contribuições dessas abordagens teóricas, poder-se-ia assegurar que a participação do Legislativo na produção das políticas é muito baixa, face a predominância e o controle do Executivo, e, que quando se dá, ela orientase basicamente à produção de políticas públicas que privilegiam interesses particularistas

\footnotetext{
${ }^{2}$ A expressão tem origem no período da Guerra Civil americana e indicava a prática de distribuir carne de porco salgada aos escravos nas plantações como uma recompensa. Era um sinal de bondade do dono da plantação, porque a carne não era comum na dieta dos trabalhadores. Em troca, os senhores se divertiam ao ver os escravos disputarem entre si, com grande alarido, as peças de carne dentro de um barril de madeira, e ainda lhes agradecer. O termo evoluiu, e passou a designar gastos arbitrários do Estado, destinados a distribuir benesses e comprar a aprovação da população. Esse termo possui, então, uma acepção pejorativa e tem sido substituído por alguns autores por políticas distributivistas do tipo restrito. Apesar das diferenças que alguns acadêmicos imputam entre os conceitos, esses serão usados neste trabalho como sinônimos e adotar-se-á a seguinte definição: "Distributive policy targets discrete beneficies to especific populations such as estates and congressional districts but spreads the costs across the general population throught taxation" (EVANS, 2004: 03). A característica comum dessas benesses é serem pagas por todos os contribuintes e "beneficiarem" diretamente populações específicas, ou apenas as circunscrições eleitorais dos políticos (RICCI, 2006: 08). Estas se opõem às escolhas de políticas mais gerais que afetam toda a nação ou uma grande parte dela.
} 
(visam à obtenção de ganhos concentrados para determinados grupos com custos difusos para a sociedade, sem considerações equitativas) e menos universalistas.

Estudos seguintes sobre o tema, no entanto, preocupados em apreender os resultados da interação entre o Legislativo e o Executivo no Brasil e reavaliar os pressupostos sobre a organização institucional brasileira, têm mostrado que: (1) o Poder Legislativo não é secundário na produção de políticas públicas, já que origina projetos relevantes, bem como intervém nas propostas iniciadas pelo Executivo, promovendo alterações inclusive importantes para o aperfeiçoamento das propostas (CRUZ, 2009; AMARAL, 2009; MARTINS, 2012; FREITAS, 2014); e (2) as iniciativas dos parlamentares no Brasil não são caracterizadas por uma preponderância de políticas restritas a questões paroquiais, de cunho local, mas são majoritariamente difusoras de benefícios e têm impacto e abrangência amplos, que podem ser sentidos por todo o território nacional. (AMORIM NETO E SANTOS, 2003; ARAÚJO, 2008; LEMOS, 2001; RICCI, 2003).

O presente trabalho foi pensado e organizado em torno dessa discussão sobre a função que tem desempenhado o Poder Legislativo brasileiro na definição dos contornos das políticas públicas. Busca-se, aqui, responder às seguintes perguntas: o Poder Legislativo é autor de políticas que propõem soluções para grandes questões sociais e econômicas do país ou é o Poder Executivo a principal fonte dessas políticas? O Legislativo intervém nos projetos de autoria do Executivo, alterando-os substancialmente e imprimindo neles suas preferências? Quando participa do processo de formulação das políticas públicas, o Legislativo privilegia a defesa dos interesses gerais, da sociedade como um todo, ou de interesses particularistas, de suas clientelas eleitorais ou de grupos organizados?

Note-se que por meio do processo legislativo surgem as leis que materializam as reformas econômicas e sociais, bem como as diretrizes das políticas públicas capazes de regulamentar, distribuir ou redistribuir benefícios e custos a indivíduos e grupos organizados na sociedade civil. Nesse sentido, torna-se imprescindível entender quais os atores que as promovem (Executivo ou Legislativo, ou a interação entre eles?) e em qual direção (destinadas a reverter às assimetrias sociais características do país ou destinadas a beneficiar interesses particulares?).

Também é importante perceber que o papel desempenhado pelo Legislativo no processo de formulação das leis impacta o resultado das políticas. Por um 
lado, se os congressistas são atores marginais e o Executivo tem liberdade para perseguir as mudanças políticas que julgar necessário, então as políticas geradas correm o risco de serem pouco adequadas à satisfação das necessidades e demandas dos cidadãos e dos grupos organizados, além de serem pouco consensuais. Por outro lado, se o Legislativo é mais ativo, participativo e negocia com o Executivo, o resultado tende a ser a produção de políticas mais sustentáveis ou estáveis no tempo, tendo em vista decorrerem de um consenso político e social mais amplo e de um debate mais abrangente (SAIEGH, 2008) ${ }^{3}$.

Para lançar luz sob as questões propostas, será examinada uma área das políticas públicas sociais ainda pouco estudada, qual seja: a das políticas trabalhistas e sindicais. A escolha dessa área específica de política também deveu-se a alguns outros fatores: (1) as políticas trabalhistas incluem-se no âmbito das políticas sociais, para as quais não há tema de domínio preponderante ou exclusivo nem do Congresso nem do Presidente, como é o caso, por exemplo, de assuntos na área administrativa (criação e extinção de cargos e órgãos públicos, etc.) e financeira ; (2) essa área temática está na agenda dos dois Poderes há um relativamente longo período de tempo (pelo menos desde a Constituição de 1988), o que permite avaliar os aspectos da interação ExecutivoLegislativo no decorrer do tempo; (3) a área mobiliza diversos interesses e tem, historicamente, despertado conflitos sociais e políticos, dividido opiniões, mobilizado setores organizados da sociedade e envolvido a atuação tanto do Executivo quanto do Legislativo; e (4) os direitos trabalhistas e sindicais foram um dos temas salientes da Constituição Federal de 1988, constando, desde então, de numerosas proposições de autoria de ambos Poderes. (DINIZ, 2005)

Há escassos estudos que buscam compreender o comportamento parlamentar, dentro do processo legislativo, a partir de temas específicos de políticas públicas. Entre os trabalhos que se voltam para recortes temáticos, cita-se o de Lemos (2001) sobre as características das escolhas dos parlamentares brasileiros nas áreas de educação e saúde, no período de 1988 a 1994. Outro estudo, realizado por Ricci e Lemos

\footnotetext{
${ }^{3}$ Essa visão não é, porém, consensual. Para alguns (HAGGARD E KAUFFMAN, 1995 apud TAVARES DE ALMEIDA, 1999), a capacidade de decisão autônoma do Presidente e concretização das suas preferências são essenciais para preservar as políticas e as reformas contra os incentivos distributivos, eleitoreiros, contingentes e imediatistas dos políticos, que os fazem preferir ganhos de curto prazo a benefícios maiores no futuro.
} 
(2004) e focado na Comissão de Agricultura e Política Rural da Câmara dos Deputados (CAPR), examinou a participação dos legisladores produção das leis na área agrícola, no período de 1991 a 2003. Martins (2012) analisou o papel do Legislativo e sua interação com o Executivo na definição de políticas de educação após 1995. Do mesmo modo, Gomes (2011) analisou a interação entre Executivo e Legislativo em proposições na área da saúde entre 1999 e 2006.

A consideração de políticas públicas específicas, como a apresentada nestes trabalhos e perseguida por esta pesquisa, permite avaliar mais profundamente a natureza das agendas de cada Poder e da legislação produzida a partir da relação entre eles. Análises sobre políticas especificas, ademais, podem revelar padrões diferenciados de interação entre os Poderes segundo o conteúdo e relevância dos temas abordados.

A primeira hipótese descritiva central a ser verificada neste trabalho é de que os parlamentares desempenham papel ativo no processo de conformação das políticas trabalhistas e sindicais. Destaque-se que o caráter ativo do Legislativo pode ser analisado seja pela alta proposição e aprovação das matérias de sua autoria, seja por meio do bloqueio às propostas do Executivo, ou seja pela reformulação/emendamento das iniciativas desse Poder. Aqui, conjectura-se que os parlamentares brasileiros, dados os amplos poderes legislativos do Presidente, não imprimem suas contribuições nas políticas trabalhistas por meio da autoria de leis ou por meio da resistência instransponível ao avanço das reformas pretendidas pelo chefe do Executivo. Presume-se, isso sim, que a participação dos legisladores no desenho das políticas se dá, majoritariamente, por meio de interferências nos textos das propostas originadas no Executivo, via processo de emendamento. Os recursos institucionais à disposição dos parlamentares para promover alterações nos textos das proposições apresentadas (emendas e substitutivos), garantem ao Legislativo uma sequência de negociações com o Executivo que visam a aproximar o texto final dos projetos de suas preferências.

A segunda hipótese central é que, dados os incentivos eleitorais e a prevalência do voto pessoal no Brasil, os parlamentares, em matérias trabalhistas e sindicais, privilegiam as propostas de impacto local ou paroquial, que visam a dispensar benefícios, especialmente, para áreas de contornos geográficos limitados e específicos (como uma região ou município). Segundo essa lógica, que se pretende testar, seriam preponderantes entre as propostas dos deputados federais na seara trabalhista e sindical aquelas como: a Lei argentina $\mathrm{n}^{\circ} 24.031 / 1991$, que trata da concessão de terrenos aos 
pescadores de Buenos Aires; a Lei brasileira n 427/1948, que equipara o Corpo de Bombeiros do Distrito Federal às polícias militares, para o fim de gozar das vantagens e predicamentos deste; a Lei brasileira $n^{\circ} 6.634 / 1979$, que obriga as empresas que operam na Faixa de Fronteira a terem pelo menos 2/3 (dois terços) de trabalhadores brasileiros; entre outros.

Para operacionalizar a análise, realizou-se um levantamento dos projetos de lei ordinária e das propostas de emenda à Constituição sobre o tema, de autoria do Executivo e dos deputados federais apresentados e aprovados nas últimas legislaturas (período de janeiro de 2003 a dezembro de 2014), no âmbito da Câmara dos Deputados. Também foram objetos deste estudo as Medidas Provisórias. Replicou-se, em boa medida, com algumas modificações, aplicações metodológicas utilizadas em outros estudos, especialmente no que diz respeito ao exame do conteúdo das proposições apresentadas pelos deputados.

No período analisado, o Poder Executivo Federal, as grandes organizações patronais e os principais movimentos sociais trabalhistas estiveram empenhados na promoção de alterações do arcabouço legal brasileiro que orienta as relações individuais e coletivas de trabalho. Ademais, o período foi marcado por grandes expectativas e grandes discussões em torno dos rumos da política trabalhista tendo em vista corresponder à ascensão do Partido dos Trabalhadores (PT) ao Executivo. A orientação mais à esquerda do espectro ideológico do partido no governo pode refletir sobre o volume e o conteúdo das inciativas legislativas na área de política trabalhista e sindical.

Antecipando alguns resultados, as evidências encontradas confirmam o que já vinha sendo observado nos estudos mais recentes. O Legislativo tem exercido papel ativo na produção de políticas trabalhistas e sindicais. Além de serem mais propositivos do que o Executivo nessa matéria, os deputados federais converteram em norma jurídica, durante o período estudado, em números absolutos, mais projetos do que o Poder Executivo. Do mesmo modo, verificou-se que eles intervêm substancialmente nas iniciativas trabalhistas originadas pelo Executivo.

Ademais, contrariando a perspectiva distribuitivista, observou-se uma predominância de impacto amplo e não geograficamente limitado nas propostas dos parlamentares, independentemente da vinculação partidária. $\mathrm{O}$ fato é que há restrições de natureza constitucional que impedem que sejam aprovadas leis federais que tenham 
impacto meramente regional, estadual ou municipal ${ }^{4}$. Diante dessa limitação, os deputados federais parecem privilegiar a proposição e aprovação de projetos de impacto setorial, que favorecem grupos de interesse específicos, tais como categorias profissionais ou entidades sindicais.

O estudo está dividido em seis seções. Na primeira, é feita uma revisão da literatura sobre o Legislativo brasileiro e os pressupostos que orientam esses estudos. A segunda seção trata dos debates políticos em torno da questão trabalhista no Brasil. A parte seguinte detém-se a definir os aspectos metodológicos que orientaram a elaboração da pesquisa, apresentando, em especial, as tipologias criadas para a classificação dos projetos (nacional, setorial, local ou individual). Nas seções seguintes, passa-se à análise dos dados e à apresentação dos padrões de comportamento legislativo em termos de apresentação, rejeição, aprovação e emendamento de projetos trabalhistas. Os detalhamentos acerca dos principais fatores que alteram as preferências dos políticos quanto ao tipo de política a perseguir, tornando-os mais propensos à defesa de propostas de impacto amplo e não paroquial, são objeto da quinta seção deste trabalho. Por fim, na última parte, oferece-se uma leitura conclusiva dos principais achados da pesquisa.

Pretende-se a partir deste estudo contribuir para o melhor entendimento sobre as políticas públicas que tramitam pelo Congresso e aproximar nosso conhecimento sobre a atuação do Legislativo em políticas específicas, bem como apresentar indícios para corroborar a ideia de que mesmo num ambiente conhecido pelo amplo domínio do Executivo na produção legal, existe espaço para o Legislativo expressar suas preferências políticas.

\footnotetext{
${ }^{4}$ Conforme o art. 24, $\S 1^{\circ}$, da Constituição de 1988 "no âmbito da legislação concorrente, a competência da União limitar-se-á a estabelecer normas gerais". Nesse sentido, matéria legislativa que teve origem no Congresso Nacional deve ter característica de norma geral.
} 


\section{2 - PRESSUPOSTOS TEÓRICOS SOBRE A INTERAÇÃO ENTRE O LEGISLATIVO E O EXECUTIVO NO BRASIL}

Os estudos sobre o funcionamento do Congresso Nacional, o comportamento dos parlamentares e a relação Executivo-Legislativo no Brasil são relativamente recentes. Eles emergem a partir de meados dos anos 1980 com especial concentração na década de 1990. De maneira geral, esses estudos podem ser agrupados em dois conjuntos de abordagens, cujos pressupostos têm guiado, em grande medida, os estudos sobre o legislativo brasileiro.

O primeiro conjunto é exemplificado pelos trabalhos de brasilianistas como Barry Ames (2001) e Scott Mainwaring (1999), que enfatizaram a influência das regras eleitorais de seleção dos legisladores como determinantes do comportamento dos parlamentares na arena legislativa e do conteúdo e abrangência das propostas legislativas de origem parlamentar. Segundo essa visão, a lógica do sistema eleitoral adotado no Brasil para escolha dos membros da Câmara dos Deputados, com representação proporcional de lista aberta, incentiva o voto personalizado, fragilizando os partidos e tornando frouxa a sua organização. As evidências que sustentam tal constatação passariam, sobretudo, pela tendência à personalização das campanhas eleitorais, pela perda de importância em termos de estruturação das preferências de clivagem ideológica e pela baixa taxa de identificação partidária dos eleitores, que quando perguntados sobre os critérios utilizados para a determinação do voto, afirmam decidir, majoritariamente, com base nas qualidades pessoais dos candidatos, independentemente dos partidos a que esses estejam filiados (MAINWARING, 2001:169).

Segundo essa perspectiva, o domínio das características individuais do político sobre a componente partidária identificado durante o jogo eleitoral ressoa sobre a arena legislativa e torna descentralizada a estrutura decisória no interior do Congresso. Dessa forma, os congressistas brasileiros, interessados eminentemente em sua reeleição, conduziriam seus trabalhos no Parlamento de modo a privilegiar laços pessoais e não partidários com os seus eleitores. Além disso, o modelo de seleção dos representantes da Câmara impulsionaria o apego dos parlamentares a políticas do tipo pork barrel, em favor do seu eleitorado pessoal e de seus interesses privados, em contraposição a políticas nacionais (AMES, 2001:185-186). Assim, o importante para se ter sucesso na carreira política não seria a provisão de bens públicos, mas sim a distribuição de benefícios particulares. 
A participação dos parlamentares brasileiros no processo de elaboração do orçamento ocupa posição central na exemplificação do argumento. As emendas apresentadas individualmente ao orçamento pelos deputados aparecem como o instrumento principal por meio do qual eles alocam recursos para suas clientelas eleitorais e atendem as suas demandas, com a expectativa de que os benefícios decorrentes das emendas possam ser convertidos, futuramente, em votos. Por serem exíguos canais de valorização de políticas distributivistas e, consequentemente, um recurso dotado de alta liquidez eleitoral, a execução de emendas orçamentárias, teria, à luz desse argumento, incontestável valoração positiva dos legisladores.

Segundo essa primeira abordagem, além dos reflexos sobre o comportamento dos parlamentares e sobre a importância dos partidos dentro do Congresso, as regras eleitorais criariam incentivos desfavoráveis à governabilidade democrática e fariam do Legislativo um obstáculo às iniciativas do Executivo. Esse diagnóstico pouco otimista decorre da verificação das especificidades do presidencialismo brasileiro, que conjuga sistema proporcional de lista aberta e multipartidarismo. Nesse sistema de seleção dos legisladores pelos cidadãos, há baixa probabilidade de apenas um partido conquistar a maioria das cadeiras no Parlamento, o que traria como consequência para o Presidente eleito escasso apoio no Legislativo. Em última instância, isso concorreria para a inviabilização do êxito das propostas do governo e de sua agenda e para o risco de paralisia decisória do sistema político brasileiro.

Em contraposição a essa visão, o segundo conjunto de estudos sobre o Legislativo brasileiro, do qual fazem parte, por exemplo, Argelina Figueiredo e Limongi (2002), assegura que não há evidências empíricas de problemas de governabilidade no Brasil, dada a inegável capacidade que o Executivo tem demonstrado para formar maiorias no Congresso, negociar a aprovação de suas iniciativas e controlar os parlamentares, limitando os efeitos decorrentes da arena eleitoral e tornando inócua a ação independente e individual dos legisladores sobre outputs do processo legislativo. Isso tem sido possível mediante a atuação simultânea de dois elementos: alta concentração de poderes legislativos nas mãos do Presidente e a centralização do processo decisório no interior do Legislativo (FIGUEIREDO e LIMONGI, 2002: 306).

A Carta de 1988 promoveu um rearranjo institucional que garantiu ao Presidente da República mecanismos que têm limitado a ação independente e auto interessada dos parlamentares, forçando-os a cooperar com o Executivo e a aprovar sua 
agenda. Entre esses mecanismos destacam-se: edição de Medidas Provisórias, solicitação de urgência para projetos de lei de sua iniciativa e possibilidade de vetar, total ou parcialmente ${ }^{5}$, projetos que considerar inconstitucional ou contrário ao interesse público. Além disso, a Constituição garantiu ao Executivo o controle sobre o Orçamento Público e a autonomia para nomear e demitir ministros de Estado e titulares de agências estatais de destacada relevância (Banco Central, Banco do Brasil, Caixa Econômica Federal, Petrobras, etc.).

Dentre esses poderes de que dispõe o Executivo para interferir no processo Legislativo, a permissão de edição de Medidas Provisórias (MPs) tem sido com frequência apontada, tanto nas discussões políticas quanto acadêmicas (PEREIRA e MULLER, 2000; SANTOS, 1997), como uma das principais responsáveis por esta predominância do Executivo, pois lhe confere, em sua relação com o Legislativo, enorme capacidade de definição da agenda do país. As MPs prejudicam o ritmo normal dos trabalhos legislativos, atraindo para si, durante sua tramitação, toda a atenção. Se o Congresso não votar uma Medida Provisória no prazo de 45 dias de sua publicação, ela automaticamente vai para o topo da agenda do plenário das duas Casas do Congresso, adquirindo prioridade e obstruindo a votação de propostas que vinham sendo discutidas anteriormente.

De acordo com a Constituição, a Medida Provisória só deve ser usada em situações específicas (casos de relevância e urgência), mas na prática o Executivo tem feito uso indiscriminado desse dispositivo. O número total de MPs cresce a cada legislatura e a sua prioridade de votação faz com que a pauta de deliberações dos plenários das duas Casas do Congresso Nacional permaneça quase o ano inteiro trancada, impedindo a apreciação de outras matérias que não MPs, sobretudo propostas de autoria dos próprios deputados e senadores.

A situação por diversas vezes já despertou a preocupação e o desconforto dos parlamentares, compelindo o Congresso Nacional a buscar um novo texto que restabelecesse o equilíbrio das competências constitucionais de cada Poder e propiciasse a votação de uma agenda alternativa à do Executivo.

As discussões culminaram com a promulgação da Emenda Constitucional $\mathrm{n}^{\circ}$ 32, em setembro de 2001 e com a recente decisão do presidente da Câmara em 2009,

\footnotetext{
${ }^{5} \mathrm{O}$ veto será total quando incidir sobre todo o projeto de lei e parcial quando recair sobre apenas alguns de seus dispositivos.
} 
Deputado Federal Michel Temer (PMDB/SP), de garantir nova interpretação ao rito de tramitação de MPs. A PEC, que tinha como um de seus objetivos principais mitigar o ímpeto do Executivo de governar via Medidas Provisória, eliminou a possibilidade de reedição e estabeleceu que as MPs teriam validade de 60 dias, prorrogáveis por mais 60. Já a decisão de Temer permitiu colocar em votação plenária, na Câmara dos Deputados, projetos e matérias independente do trancamento de pauta por MPs. Ao contrário da PEC, a estratégia encontrada não pretendeu reduzir o número de MPs editadas, pelo menos não diretamente. Seu intuito central foi garantir mais tempo e espaço para que os parlamentares pudessem apreciar mais matérias de sua própria autoria do que propostas do Executivo. A nova interpretação permitiu que em 2009, depois de pelo menos 7 (sete) anos, o volume de matérias de iniciativa dos parlamentares aprovadas no plenário da Câmara dos Deputados superasse o número de propostas aprovadas de iniciativa do Executivo. Para se ter uma ideia, de 2002 (quando entrou em vigor a PEC 32) até 2008, a cada projeto de autoria dos próprios deputados aprovado pelo plenário da Câmara dos Deputados, 3 (três) de origem no Executivo eram aprovados ${ }^{6}$. Em 2009, no entanto, com a decisão de Temer, foram aprovados 46 projetos de autoria dos parlamentares contra 42 do Executivo ${ }^{7}$.

Outra prerrogativa constitucional que tem garantido ao Presidente a capacidade de interferir na atividade legislativa é o direito de requer urgência para os seus projetos. Tramitação em urgência significa que o pronunciamento da Câmara sobre certa matéria deve ser feito no prazo de 45 dias, inferior ao que normalmente se necessita para apreciar determinado assunto, especialmente quando este é complexo e envolve vários interesses.

As prerrogativas legislativas, como se vê, fazem com que o Executivo ocupe estrategicamente a agenda da Câmara e retire o tempo destinado ao exame e continuidade da tramitação de matérias originadas no Legislativo. É evidente que quanto maior o tempo gasto para deliberação de matérias enviadas por iniciativa presidencial, menor o tempo livre para considerar matérias originadas na própria Câmara. Afiança-se, portanto, a primazia do Presidente sobre o Congresso no processo decisório, assegura-se a posição

\footnotetext{
${ }^{6}$ Os dados foram coletados a partir de informações disponibilizadas pela Agência Câmara.

7 O levantamento, até 16/12/2009, inclui Propostas de Emenda à Constituição, Medidas provisórias, Projetos de Lei Complementar, Projetos de Lei e Projetos de Resolução; não foram computados Projetos de Decreto Legislativo.
} 
do Executivo como ator central do processo legiferante e limita-se a capacidade do Congresso de deliberar matérias que não as originadas no Executivo.

Outro fator responsável pelo sucesso do Executivo na aprovação de suas propostas, que tem impedido que o Legislativo funcione como um obstáculo a sua ação governativa, conforme identificado pelos autores da primeira abordagem, é a habilidade manifestada por este Poder de criar uma coalizão (não necessariamente fundada em afinidades ideológicas ou programáticas) e angariar o apoio dos parlamentares por meio da utilização estratégica do funcionamento do Congresso, que centraliza o poder decisório nas mãos dos líderes partidários. As prerrogativas previstas nos Regimentos Internos das Casas Legislativas reforçam o papel dos partidos, que passam a exercer controle sobre seus representantes, obrigando-os a, no momento das votações em plenário, serem disciplinados e a atuarem de forma coesa. Entre essas atribuições estão, por exemplo, a nomeação e a destituição dos parlamentares que irão compor as Comissões Temáticas, a nomeação dos relatores dos projetos, a inclusão e a retirada de projetos de pauta, e a concentração de deliberações sobre temas substantivos no Colégio de Líderes (SANTOS, 2003; PEREIRA E MULLER, 2000: 48).

A centralização das decisões no interior do Congresso favorece o Executivo, pois viabiliza acordos políticos em seu favor ao diminuir os custos e as incertezas associados a uma negociação na qual se tem que apelar a cada parlamentar tomado individualmente. As negociações e barganhas entre o Executivo e as lideranças partidárias, normalmente envolvem promessa de liberação de emendas orçamentárias, garantia de acesso a postos ministeriais, ou ainda, deliberada compra de votos.

A conjunção desses recursos institucionais motiva o empírico domínio do Executivo sobre Legislativo e a preponderância da iniciativa legislativa governamental em detrimento da parlamentar. Esses aspectos ficam evidentes, sobretudo, quando observada a produção normativa (o que de fato foi deliberado), em especial pelo Plenário da Câmara dos Deputados. Conforme Figueiredo e Limongi,

(...) desde a promulgação da Constituição de 1988, a taxa de sucesso do Executivo, isto é, a proporção de projetos aprovados sobre o total de enviados, gira em torno de $90 \%$. Rejeições pelo Legislativo dos projetos enviados pelo Executivo são fatos raros: não mais que 10\%. Além disto, a produção legislativa é claramente dominada pelo Executivo: do total de 3043 leis aprovadas entre 1989 e 2001, 86\% foram propostas pelo Executivo. (2004: 53) 
Essa prevalência das preferências do Executivo e seu controle sobre a agenda do Legislativo, tanto no que se refere ao conteúdo das matérias quanto ao ritmo de tramitação das mesmas, é denominada de "poder de agenda" do Executivo, responsável pelo papel coadjuvante que representam os parlamentares no processo de elaboração das leis e pela limitação da capacidade do Legislativo de concluir a tramitação de suas próprias propostas.

O poder de agenda do Executivo e seu consequente predomínio entre as propostas aprovadas e transformadas em norma jurídica, seria o principal responsável por garantir que a legislação resultante do processo legislativo tenha predominantemente abrangência nacional, já que o Presidente da República, eleito conforme as regras do sistema majoritário, teria menos incentivos para o envolvimento em pork e maiores incentivos para responder a demandas nacionais. Reduzir-se-ia assim o paroquialismo e ampliar-se-ia a abrangência das políticas públicas.

Esses dois modelos usados como referencial para compreensão do Legislativo brasileiro, são por vezes ambíguos entre si, conforme pode-se observar no Quadro 1 abaixo. Ora o Legislativo é visto como um obstáculo instransponível e principal fonte de resistência ao avanço das reformas pretendidas pelo chefe do Executivo. Ora o Legislativo é rotulado de fraco frente ao Executivo, sendo visto como um ator passivo frente as preferências e iniciativas do Executivo. 


\section{Quadro 1- Síntese das abordagens apresentadas sobre o comportamento dos deputados federais}

\begin{tabular}{|c|c|c|}
\hline & $1^{a}$ abordagem & $2^{\mathrm{a}}$ abordagem \\
\hline $\begin{array}{l}\text { Arena } \\
\text { eleitoral }\end{array}$ & - Personalizada, individualista. & - Personalizada, individualista. \\
\hline $\begin{array}{l}\text { Deputados } \\
\text { na arena } \\
\text { legislativa }\end{array}$ & $\begin{array}{l}\text { - Individualistas e paroquialistas; } \\
\text { - As regras eleitorais moldam o } \\
\text { comportamento dos deputados dentro do } \\
\text { Parlamento. }\end{array}$ & $\begin{array}{l}\text { - Estruturado pelos partidos; } \\
\text { - A concentração de poderes no Executivo e } \\
\text { centralização das decisões no Congresso } \\
\text { determinam a performance dos deputados. }\end{array}$ \\
\hline Estratégia & $\begin{array}{l}\text { - Para maximizar suas chances de reeleição } \\
\text { e de sobrevivência na política, adotarão a } \\
\text { estratégia de transferir benefícios a seus } \\
\text { redutos eleitorais, ou seja, benefícios } \\
\text { concentrados nas localidades onde tiveram } \\
\text { maior número de votos na eleição anterior, } \\
\text { e não espalhados nacionalmente. }\end{array}$ & $\begin{array}{l}\text { - "O curso da ação racional é atuar por meio } \\
\text { dos partidos, a única forma mediante a qual } \\
\text { os políticos serão capazes de ter influência } \\
\text { sobre as políticas públicas e, assim, pleitear } \\
\text { mandatos junto ao eleitorado" (Figueiredo e } \\
\text { Limongi, 2002: 306) } \\
\text { - Votar com o governo e seguir as diretrizes } \\
\text { da liderança partidária é a estratégia que lhes } \\
\text { permite melhor acessar os recursos e } \\
\text { benefícios controlados pelo Executivo. } \\
\text { Benefícios esses que lhes garantem maiores } \\
\text { retornos eleitorais, já que podem distribuí-los } \\
\text { a sua circunscrição eleitoral, com a } \\
\text { expectativa de vê-los convertidos em votos. }\end{array}$ \\
\hline Resultado & $\begin{array}{l}\text { - Confronto entre o Executivo e o } \\
\text { Legislativo; } \\
\text { - O Executivo tem escasso apoio no } \\
\text { Legislativo. O processo de construção de } \\
\text { base de apoio ao governo é custoso. O êxito } \\
\text { das propostas do governo é comprometido } \\
\text { e o sistema político fica submetido ao risco } \\
\text { de paralisia decisória; } \\
\text { - Tendência à produção legislativa de } \\
\text { origem parlamentar de tipo paroquialista, } \\
\text { ou seja, voltada para a provisão de } \\
\text { benefícios locais, geograficamente } \\
\text { identificados (pork). }\end{array}$ & $\begin{array}{l}\text { - Cooperação entre o Executivo e o } \\
\text { Legislativo; } \\
\text { - O Executivo é capaz de formar e manter } \\
\text { uma base de apoio no Congresso, utilizando- } \\
\text { se de seus poderes constitucionais e das } \\
\text { regras internas do Congresso, que centraliza } \\
\text { o poder decisório nas mãos dos líderes } \\
\text { partidários; } \\
\text { - A lógica da ação legislativa centrada no } \\
\text { partido diminui as atividades clientelistas de } \\
\text { cunho local, portanto, a produção legislativa } \\
\text { tende a servir a interesses mais gerais, ou } \\
\text { nacionais. }\end{array}$ \\
\hline
\end{tabular}

Fonte: Quadro elaborado pela autora (2015).

\section{1 - Legislativo como ator relevante na formulação das políticas}

Apesar do robusto suporte empírico do domínio do Executivo sobre Legislativo, alguns estudos indicam que essa predominância possa estar sendo 
superestimada (DINIZ 2005; CRUZ, 2009; AMARAL, 2009; GOMES, 2011; MARTINS, 2012; TAVARES DE ALMEIDA, 1999; LOPES, 2013). O Executivo tem evidentemente conseguido pautar e aprovar a maioria de seus projetos. No entanto, essa taxa de sucesso não revela a existência ou não de intervenções feitas pelos parlamentares nas propostas oriundas do Poder Executivo. Os legisladores possuem a sua disposição recursos institucionais (emendas e substitutivos) que permitem-nos promover alterações nos textos das proposições apresentadas, de modo que o Executivo não necessariamente consegue manter incólume o texto original de suas matérias.

Em sua pesquisa, Cruz (2009) analisou 191 projetos de lei de autoria do Poder Executivo apresentados entre 1999 e 2006, que foram transformados em lei. Em seus resultados a autora aponta que mais de $70 \%$ dos projetos selecionados (total de 141) receberam emendas de parlamentares durante a tramitação no Congresso. Entre esses projetos de lei do Executivo modificados, 85 projetos tramitaram na Câmara dos Deputados em regime de urgência. Destes, 51 sofreram alterações que podem ser consideradas substanciais (substitutivo, emenda aglutinativa e emenda substitutiva).

Amaral (2009) também observou que a Câmara dos Deputados alterou 76\% dos projetos de lei ordinária apresentados pelo Executivo entre 1995 e 1996, sendo as alterações feitas, em sua maioria $(67,9 \%)$, por meio de substitutivo.

Martins (2012), por sua vez, aponta que a participação do Poder Legislativo na revisão de propostas do Presidente da República foi bastante elevada na área educacional entre 1995 e 2010. Os dados apresentados pelo autor demonstram que dos 43 projetos (projetos de lei ordinária e Medidas Provisórias) iniciadas pelo Executivo, 15 foram aprovados sem alteração, 10 foram alvos de emendas e 24 foram objeto de um substitutivo (alterou significativamente o conteúdo do texto original). Do mesmo modo, Gomes (2011), analisando a interação entre Executivo e Legislativo na área da saúde, observou uma intensa atividade de modificação das proposições em todas as vias (constitucional, complementar e ordinária) entre 1999 e $2006^{8}$.

Lopes (2013), ao examinar a participação do Legislativo na definição das políticas do setor agrícola/agrário, também verificou uma expressiva intervenção do

\footnotetext{
${ }^{8}$ Conforme dados do autor, na via constitucional, 77, 8\% das 9 emendas constitucionais relacionadas à saúde foram objeto de emenda substitutiva (tipo que geralmente produz alterações de maior abrangência) durante sua tramitação na Câmara. Na via complementar, as duas leis foram objeto de substitutivo. Na via ordinária, em 74, $2 \%$ das 66 MPV convertidas em lei foram apresentadas emendas (em 9 casos foram mais de 100 emendas, e no mais extremo, 572 emendas). Em 58\% das MPV foi necessário elaborar um projeto de lei de conversão, indicando que o texto foi efetivamente modificado pelo Legislativo.
} 
Poder Legislativo, por meio da apresentação e aprovação de emendas, alterando significativamente os textos originais das proposições enviadas, incluindo as políticas do Executivo. Conforme o autor, do total de 48 matérias sancionadas entre 2003 e 2010, houve intervenção do poder Legislativo em $66,67 \%$ dos casos.

Diniz (2005), analisando a área de políticas trabalhistas, conclui que o desempenho legislativo do Executivo nessa área de política dependeu menos de seus poderes discricionários e mais de um jogo estratégico com os congressistas, operado por meio de consultas ou períodos de julgamentos de reações antecipadas. Também Tavares de Almeida (1999), examinando as políticas de privatizações da década de 1990, afirmou que "o Congresso atuou sobre uma pauta que não foi por ele definida, mas sua atuação não foi irrelevante. Todo o arcabouço legal da política de privatização foi discutido e negociado no Legislativo" (1999: 130).

Importante notar que esses estudos não oferecem conclusões valorativas a respeito a participação do Legislativo, bem como não demonstram que toda a alteração por parte do Legislativo é contrária aos interesses do Executivo. Porém, esses trabalhos reúnem evidências que lançam dúvidas sobre a percepção dos legisladores como atores fracos e meros chanceladores das iniciativas presidenciais ao revelarem a intervenção significativa do Poder Legislativo no conteúdo dos projetos aprovados e convertidos em norma jurídica. Eles demonstram que o Poder Legislativo, apesar de não ser o autor principal das normas federais no Brasil, opera nos textos enviados pelo Executivo, alterando muitas vezes a intenção geral da proposta, a partir de emendas e de substitutivos apresentados. Por isso, afirmam que a preponderância do Executivo está sendo superestimada, tendo em vista a ênfase dada à autoria do projeto transformado em lei e aos meios utilizados pelo Executivo para limitar a ação do Legislativo e anular os interesses particulares que guiariam a ação dos parlamentares.

Essas análises a respeito da força do Legislativo no processo de formulação das leis impõe uma reflexão relevante: se, por um lado, é desejável que esse Poder seja ativo, de modo a garantir a eficácia do funcionamento do sistema de representação e, por conseguinte, a qualidade da democracia, por outro lado, sua capacidade interventiva pode comprometer a governabilidade e possibilitar a chamada paralisia decisória. No Brasil, o Legislativo não é tão ativo e construtivo quanto o Congresso norte-americano (SAIEGH,2008), por exemplo, tendo em vista converter em leis proporcionalmente menos propostas que o Executivo. Também não há evidências de que o Legislativo 
brasileiro funcione majoritariamente como um bloqueador das propostas do Poder Executivo a ponto de obstaculizar à inovação em políticas estruturantes e romper com o equilíbrio da governabilidade ${ }^{9}$. O que as análises parecem sugerir é que no sistema brasileiro prevalece um processo de negociação entre os dois Poderes no que concerne ao conteúdo das políticas, já que o Poder Executivo intenciona aprovar seus projetos sem alterações significativas, enquanto os parlamentares buscam aproximar o conteúdo das políticas aos seus interesses. Esse processo de negociação ancora-se na possibilidade de revisão legislativa (emendamento), por meio da qual busca-se solucionar os conflitos de preferência.

Poder-se-ia argumentar, no entanto, que, conforme o modelo brasileiro, as interferências dos congressistas nos textos de autoria do Executivo não são tão relevantes, já que uma alteração substantiva que mude a vontade do Presidente pode ser por ele revertida mediante veto. Como se sabe, o Executivo pode valer-se tanto do veto total quanto do parcial para bloquear algumas mudanças na legislação. O fato, porém, é que no Direito brasileiro o veto é superável e a última palavra, de qualquer forma, é do Congresso Nacional. Tanto o veto total quanto o parcial podem ser derrubados pelo Legislativo, desde que aprovado por maioria absoluta dos Deputados e Senadores, em escrutínio secreto, em sessão conjunta do Congresso Nacional (CF, art. 66, § $\left.4^{\circ}\right)$. Apesar de serem raras as sessões do Congresso Nacional que objetivam apreciar vetos e de boa parte deles, quando apreciados, serem mantidos, também são poucas as leis sancionadas pelo Presidente com vetos ${ }^{10}$.

\section{2 - Legislativo voltado para a produção de políticas de impacto amplo}

Com relação ao conteúdo da legislação originária do Congresso brasileiro, uma série de análises (LEMOS, 2001; AMORIM NETO e SANTOS, 2003; CARVALHO, 2003; RICCI, 2003; ARAÚJO, 2008) também têm contrariado o raciocínio intuitivo, defendido pelos teóricos da abordagem distributivista, de que este é

\footnotetext{
${ }^{9}$ Há certo reconhecimento internacional de que o Brasil tem conseguido implementar políticas consistentes e estáveis, em oposição à tese da paralisia decisória e da crise de governabilidade, expressas, por exemplo, na implementação de programas de atenção primária à saúde que contribuíram para a redução da mortalidade infantil; nas conquistas das políticas de educação e saúde; e na agilidade com que as instituições brasileiras responderam à crise econômico-financeira mundial iniciada em 2008, em comparação com países europeus. (GOMES, 2011: 26)

${ }^{10}$ Para se ter uma ideia, entre 2010 e 2014 foram editadas um total de 887 leis ordinárias, das quais apenas $17,4 \%$ foram alvo de vetos (totais ou parciais).
} 
voltado majoritariamente para concentrar benefícios e satisfazer interesses de grupos geograficamente circunscritos ao reduto eleitoral no qual o parlamentar obteve mais votos, e não para distribuir benefícios por todo o estado do respectivo parlamentar e muito menos por todo território nacional. Nesse sentido, o que essas análises recentes sustentam é que o formato atual da produção legislativa ordinária no Brasil é caracterizado por uma preponderância de normas gerais, que não atendem aos requisitos do particularismo.

Amorim Neto e Santos (2003) analisaram todos os projetos de lei de deputados transformados em lei entre 1985 e 1995, bem como os projetos por eles apresentados em 1995. Quanto aos convertidos em lei, a conclusão é que possuem, majoritariamente abrangência nacional, ou seja, afetam indiscriminadamente todos os grupos de cidadãos, estados regiões e municípios (72,4\% dos projetos de lei); trazem mais benefícios do que impõe custos $(49,1 \%$ dos projetos); e tratam de questões sociais $(57,1 \%$ dos projetos). Quanto aos projetos apresentados pelos deputados, os resultados apontam no mesmo sentido. Ou seja, a maioria tem abrangência nacional $(72,4 \%)$, efeitos benéficos $(55,5 \%)$ e versam sobre matéria social $(57,1 \%)$.

Lemos (2001) também testou o conteúdo das propostas dos deputados brasileiros nas áreas de saúde e educação, no período compreendido entre 1988 e 1994, procurando identificar se as propostas (um total de 817 ) procuravam distribuir benefícios concentrados, principalmente para as localidades geográficas que correspondem aos distritos eleitorais dos parlamentares, ou difusos, que se poderiam sentir por toda a extensão do território nacional. A hipótese testada pela autora previa que, entre os projetos dos deputados, nas áreas de educação e saúde, prevaleceriam as distributivistas, de transferência concentrada de benefícios. No entanto, a visão de deputados federais movidos pela lógica do particularismo, pelo menos nessas áreas de política, não se confirmou: $60 \%$ das iniciativas tinham caráter difuso, contra $40 \%$ com caráter concentrado. Ademais, a média de propostas concentradoras por parlamentar foi de 0,57 contra 0,83 para propostas difusoras de benefícios (LEMOS, 2001: 08).

Lemos (2004) também analisou, em parceira com Ricci (2004), as políticas para o setor agrícola. A partir do exame da produção legislativa e das preferências eleitorais dos membros da Comissão de Agricultura e Política Rural da Câmara dos Deputados (CAPADR) no período entre 1991 e 2002, os autores concluíram que as proposições que tramitavam nesta comissão eram, em sua maioria, políticas que se voltavam para temas abrangentes. 
Araújo (2008), apesar de tratar mais especificamente sobre a produção legislativa do Senado Federal, afirma que na Câmara dos Deputados os parlamentares apresentam índices baixos de leis paroquiais (ARAÚJO, 2008: 219). As conclusões também foram reforçadas por Carvalho (2003), para quem os incentivos eleitorais adentram os corredores do Congresso, mas a afirmação de que os parlamentares buscarão políticas paroquialistas com efeitos concentrados em seus restritos redutos eleitorais não pode ser generalizada por todo o Legislativo.

Segundo o autor, no Brasil, o argumento vale apenas para aqueles representantes eleitos com votos concentrados em determinados redutos eleitorais/municípios e que enfrentam pouca competição eleitoral (perfil concentrado e dominante). Parlamentares eleitos com votos espalhados por todo o estado e/ou enfrentando alta competição com concorrentes tendem a se pautar por princípios mais universalistas. As análises feitas pelo autor das eleições de 1994 e 1998 para deputados federais revelaram que, na média, apenas $17 \%$ dos representantes eleitos possuem um perfil de votação concentrado e dominante. Apenas esses parlamentares teriam incentivos para enfatizar e privilegiar entre suas atividades políticas distributivas para seus redutos, por meio, por exemplo, da consecução de emendas ao orçamento, de visita frequente a seus redutos, e do acesso aos recursos controlados pelo Executivo, que são para eles os recursos dotados de maior liquidez eleitoral.

A maioria dos deputados (83\%) é eleita, então, ou por meio de votos espalhados pelo distrito ou enfrentando grande competição com os demais candidatos. No geral, quando os votos são dispersos por diversas municipalidades, as políticas propostas passam a ter um caráter mais amplo e abrangente, para que toda a parcela do eleitorado possa ser capturada e a política por todos visualizada e reconhecida. O modelo distributivista aqui não se aplicaria, já que a abordagem pressupõe o direcionamento de benesses para áreas bem delimitadas e com contornos geográficos precisos (CARVALHO, 2003: 120).

Igualmente para Ricci (2003), as conclusões dos distributivistas sobre o Legislativo norte-americano não podem ser automaticamente aplicadas à compreensão do Legislativo brasileiro. Conforme o autor, não se deve sustentar a imagem de deputados federais envolvidos na distribuição de benefícios locais ou a ideia de legisladores que não se interessam por questões de escopo nacional. Segundo os critérios classificatórios adotados por Ricci, 66,2\% dos projetos sancionados entre o período de 1991 a 1998 têm 
abrangência nacional, beneficiando grupos espalhados por todo território nacional, contra $8,6 \%$ com impacto local e individual. O resultado, para o autor, permite dizer que a arena legislativa é capaz de encontrar acordos estáveis, duradouros e bem-sucedidos quanto ao tipo de política que privilegia a comunidade nacional (RICCI, 2003: 06).

Importante ressaltar que tais análises enfatizam a produção legislativa sob a ótica da Câmara dos Deputados e não focalizam os senadores, apesar de serem atores relevantes no processo decisório e com participação em certa medida equivalente aos deputados na produção legal, conforme estabelecido pelo arranjo institucional bicameral brasileiro, tanto do ponto de vista constitucional, quanto do ponto de vista dos regimentos internos das duas Casas. A ausência de menção à ação legislativa do Senado Federal nos estudos, no entanto, justifica-se frente aos menores incentivos eleitorais (os senadores são eleitos conforme as regras do sistema majoritário) com os quais se defrontam os senadores para o envolvimento em pork.

Diante de toda essa discussão teórica, resta ao presente trabalho identificar qual seria de fato a contribuição da Câmara dos Deputados para a conformação das políticas públicas, especificamente para as políticas trabalhistas e sindicais - objeto desta análise.

Destaque-se que há um significativo conjunto de pesquisas sobre a participação do Legislativo na construção das políticas educacionais e de saúde (LEMOS, 2001; MARTINS, 2012; GOMES, 2011), estando as políticas trabalhistas e sindicais ainda pouco exploradas dentro do espectro das políticas sociais. Torna-se importante analisar também esse tema de política, já que as taxas de sucesso e dominância do Executivo, as contribuições do Legislativo na construção do conteúdo das políticas públicas, bem como a predisposição dos parlamentares a particularismo e pork barrel podem sofrer variações em função da área de política analisada. 


\section{3 - OS DEBATES SOBRE AS QUESTÕES TRABALHISTAS E SINDICAIS NO} BRASIL

$\mathrm{O}$ aparato jurídico que fundamenta as relações trabalhistas e sindicais no Brasil tem as suas raízes na Era Vargas, especialmente em 1943 com a publicação da Consolidação das Leis do Trabalho (CLT), que regula, ao longo de seus atuais 922 artigos, tanto as relações individuais de trabalho, quanto os mecanismos de representação dos agentes econômicos. Com a CLT, surge novos interesses em torno da relação capital trabalho, seguindo uma lógica semelhante à da dependência da trajetória (path dependence $)^{11}$, segundo a qual mudanças na organização do trabalho que serão tentadas ou implantadas nas décadas seguintes terão necessariamente que lidar com esses interesses.

No âmbito das relações individuais do trabalho, a legislação varguista assegurou uma série de direitos sociais inéditos no país, como a instituição da jornada de trabalho, do salário mínimo e do direito a descanso remunerado. Com relação à estrutura sindical, a CLT instituiu juridicamente os pilares de um corporativismo estatal, quais sejam: o controle, por parte do Estado, da criação e atividades dos sindicatos; o monopólio da representação sindical, organizada por região geográfica e por categoria; o imposto sindical compulsório, pago por todos os trabalhadores, sindicalizados ou não, e a proibição da criação de centrais sindicais. Além disso, não havia previsão para a negociação direta entre empregadores e empregado, ficando a Justiça do Trabalho responsável pela resolução dos conflitos.

Em 1988, uma série de direitos já previstos na CLT ganharam status constitucional e foram consagrados pela Constituição Federal de 1988 em seus artigos $6^{\circ}$, $7^{\circ}, 8^{\circ}, 9^{\circ} 10^{\circ}$ e $11^{\circ}$. Licença gestante de 120 dias, remuneração do trabalho noturno superior à do diurno, gozo de férias correspondente a 1/3 do salário normal, direito de greve e fixação da jornada de trabalho normal em quarenta e quatro horas semanais são apenas alguns dos dispositivos legais previstos na Carta Magna. Importante frisar que a definição desses direitos trabalhistas no texto constitucional foi possível devido à

\footnotetext{
${ }^{11}$ Basicamente, segundo essa ideia, as instituições atuais são herdeiras de um legado histórico e, ao mesmo tempo, produzem trajetos que estruturam instituições futuras. Em outras palavras, as decisões políticas adotadas no passado condicionam as decisões do presente e do futuro, criando uma trajetória difícil de ser revertida ao seu ponto inicial, tendo em vista que cada decisão tomada encoraja forças sociais a se organizarem, orienta preferências, e desenvolve interesses em políticas cujo abandono envolve altos custos políticos (Hall \&Taylor, 2003: 201).
} 
existência de razoável consenso e união de forças entre as lideranças sindicais predominantes que participaram dos trabalhos da Constituinte.

Com relação à estrutura sindical, a Constituição de 1988 fortaleceu os sindicatos, tornando-os autônomos em relação ao Estado, ao prever a não obrigatoriedade de reconhecimento das entidades sindicais pelo Ministério do Trabalho, proibir a intervenção estatal nos sindicatos, garantir a sindicalização dos servidores públicos, etc. Porém, o novo texto manteve o princípio da unicidade sindical $^{12}$ e existência da contribuição sindical compulsória ${ }^{13}$ e o poder normativo da Justiça do Trabalho ${ }^{14}$ (bases de sustentação do sindicalismo oficial e corporativista construído na década de 1940), há muito considerados os principais cerceadores da atividade sindical (DINIZ, 1998:24). A inexistência de inovação nesses três aspectos deveu-se a uma divisão do debate entre as entidades sindicais, mobilizadas em duas coalizões divergentes: a primeira, representada pela Confederação Geral dos Trabalhadores (CGT) e apoiada por partidos como PCdoB, PSB, PDT e maiorias do PFL, PMDB e PL, rejeitava a ideologia do pluralismo da representação sindical, defendia o imposto sindical, o sistema confederativo e o poder normativo da Justiça do Trabalho; já a segunda, representada pela Central Única dos Trabalhadores (CUT) e apoiada pelo PT e pelas minorias do PMDB, PFL e PL, por exemplo, defendia o fim do da unicidade, das contribuições compulsórias e do poder normativo da Justiça do Trabalho. A primeira coalizão encontrava apoio, ainda, nas entidades patronais, que defendiam a estrutura oficial.

Para muitos (DA SILVA, 2007; DINIZ, 2004; NASCIMENTO, 1994), a Constituição instituiu, assim, uma configuração sindical particular e contraditória, na medida em que introduziu princípios de autonomia, mas impôs limitações à livre atuação

\footnotetext{
12 Conforme esse princípio, fica proibida a criação de mais de uma organização sindical em qualquer grau (sindicato, federação, confederação), representativa de categoria profissional ou econômica, na mesma base territorial (município, região, estado e, ainda, em todo país).

13 Atualmente vigoram quatro tipos de contribuições: a dos associados; a contribuição assistencial, descontada em folha à época da data-base, cujo valor é estabelecido em assembleia; a contribuição sindical, que equivale a um dia de trabalho de todos os trabalhadores; e a confederativa, também definida em assembleia. A principal consequência da contribuição compulsória para as entidades sindicais, inclusive as patronais, é que havendo fontes de sustentação asseguradas legalmente, não há por que as entidades sindicais se empenharem na adesão de novos sócios e assim ampliarem sua base de representação.

${ }^{14} \mathrm{O}$ poder normativo da Justiça do Trabalho consistia em uma competência para decidir, criar e modificar normas, em matéria de dissídios coletivos. Tal poder amparava-se na antiga redação do art. $114,2^{\circ}$ da Constituição Federal, que previa: recusando-se qualquer das partes à negociação ou à arbitragem, é facultado aos respectivos sindicatos ajuizar dissídio coletivo, podendo a Justiça do Trabalho estabelecer normas e condições, respeitadas as disposições convencionais e legais mínimas de proteção ao trabalho. Após a reforma do Poder Judiciário introduzida pela Emenda Constitucional no 45/2004, no entanto, foi retirada essa prerrogativa, não podendo mais as decisões dos tribunais criar normas ou condições de trabalho, devendo apenas decidir os conflitos ajuizados.
} 
sindical. Essa contradição é a principal responsável pela manutenção do tema da reforma sindical na pauta do debate político ao longo das últimas décadas e sua falta de solução até os dias de hoje.

Importante ressaltar que durante o período da Assembleia Constituinte os interesses dos sindicatos dos trabalhadores se fizeram representar pelo Departamento Intersindical de Assessoria Parlamentar (DIAP), devido à legitimidade que este dispunha entre as entidades sindicais.

A Constituição também reforçou a extensiva regulação estatal sobre as relações do trabalho e a representação sindical, mantendo o Brasil fixado à tradição vigente desde a década de 1940 de detalhismo legal, com a lei ocupando centralidade absoluta, em detrimento dos contratos e da negociação estabelecidos entre as partes. Os vários estudiosos do Direito Trabalhista (VOGEL, 2008; PASTORE, 2006) classificam, portanto, o modelo brasileiro como legislado, regulado ou estatutário, em oposição ao modelo contratual ou negociado. No primeiro, a lei é vista como principal ou único mecanismo capaz de definir os direitos substantivos do trabalho. No segundo, há maior valorização dos termos acertados entre as partes - trabalhadores e empregadores - do que da lei e das especificidades de cada setor ou atividade econômica.

Esse binômio legislado-negociado tem motivado grandes disputas e debates políticos que, grosso modo, expressam o conflito perene entre o capital e o trabalho. De um lado, estão os que veem na regulação um engessamento comprometedor da competitividade e da liberdade do capital para produzir livremente, de modo a melhor adaptar-se às flutuações da economia de mercado. De outro, os que acreditam que não é diminuindo a regulação pública do trabalho que serão superados os problemas da competitividade e que identificam nessa regulação marcos civilizatórios mínimos que evitam a precarização do mercado de trabalho brasileiro.

A agenda de prevalência dos contratos sobre o legislado ganhou maior expressão no Brasil nos anos 1990, tornando-se hegemônica, tendo em vista a tendência de mundialização da economia e a globalização das firmas e a adesão das elites nacionais ao ideário neoliberal. Nesse período, os empresários brasileiros começaram a demandar maior flexibilização da legislação, a fim de diminuírem seus custos trabalhistas e tornarem-se mais competitivos na economia global. Não raramente, a flexibilização ou desregulamentação eram apresentadas como condições necessárias para fomentar a criação de empregos, aumentar os salários e a produtividade das firmas e reduzir a 
informalidade - principais problemas do mercado de trabalho do país na época. Ademais, era defendida uma redução da interferência da Justiça do Trabalho na resolução de conflito entre as partes, passando essa função a ser exercida por meio da conciliação ou arbitragem privada, com o objetivo de que a resolução dos conflitos trabalhistas se desses de forma mais rápida.

Essa posição era defendida, sobretudo, pela Federação das Indústrias do Estado de São Paulo (Fiesp), Confederação Nacional da Agricultura (CNA), Confederação Nacional da Indústria $(\mathrm{CNI})$ e pela Federação Brasileira de Bancos (Febraban). Essas entidades apoiavam uma reforma que considerasse o negociado em local de trabalho como superior ao legislado, sem, contudo, alterar as bases tradicionais do sindicalismo patronal.

Ocupando uma posição diametralmente oposta neste debate, a CUT, acompanhada pelo Pensamento Nacional das Bases Empresariais (PNBE) e pela recémcriada Força Sindical, além de defenderem o fim da unicidade, rebatiam a agenda da flexibilização. Contudo, a CUT era a única que mantinha sua posição de maneira firme e combativa, já que o PNBE e a Força Sindical em muitos momentos se mostravam abertos ao diálogo e à negociação com o empresariado.

No meio desses dois polos estavam algumas confederações (Confederação Brasileira dos Trabalhadores em Informática - CBTI, Confederação Nacional dos Transportes - CNT, Confederação Nacional dos Trabalhadores Metalúrgicos - CNTM, Confederação Nacional dos Trabalhadores da Agricultura - Contag) e a CGT, que, basicamente, apoiavam a preservação das relações trabalhistas vigentes.

As propostas do primeiro grupo, em favor da flexibilização, avançaram sobremaneira durante o governo do Presidente Fernando Henrique Cardoso. Exemplificam o comprometimento desse governo com a agenda do patronato, por exemplo, a decisão, concretizada por meio do Decreto $\mathrm{n}^{\circ} 2.100 / 1996$, de denunciar a Convenção 158 da Organização Internacional do Trabalho (OIT), que veda a demissão de trabalhador sem justa causa. Com a decisão o Brasil deixou de aderir à Convenção.

O Presidente Fernando Henrique também encaminhou ao Congresso Nacional diversas Medidas Provisórias, por várias vezes reeditadas, com o intuito de promover a flexibilização das relações de trabalho e a auto composição dos conflitos. São elas: MP 1.053/95, que estabeleceu a livre negociação coletiva na definição de salários (após as inúmeras reedições, essa MP foi aprovada transformando-se na Lei $\mathrm{n}^{\circ}$ 
10.192/2001); MP 1.070/95, que tornou possível a adoção imediata do efeito suspensivo nos dissídios coletivos (a última edição dessa MP foi transformada na Lei nº 9.491/1997, que apenas prevê a utilização dos recursos do Fundo de Garantia do Tempo de Serviço FGTS para aquisição de ações de empresas privatizadas); a MP 1.982-77/00, que estabelece que a participação nos lucros e resultados (PLR) deve ser objeto de negociação entre a empresa e seus empregados (convertida na Lei $\mathrm{n}^{\mathrm{o}}$ 1.0101/2000); a MP 1.523/96, que determinava a rescisão contratual face à aposentadoria (transformada na Lei $\mathrm{n}^{\circ}$ 9.528/1997); entre outras.

Não só de Medidas Provisórias valeu-se o governo à época para implementar uma reforma trabalhista em direção ao modelo contratual. Também foram submetidos ao Congresso projetos de lei, tais como: PL 1724/96, que estabeleceu o contrato de trabalho por tempo determinado (transformado na Lei $\mathrm{n}^{\circ}$ 9.601/1998); PL 4693/98, que criava o rito sumaríssimo da Justiça do Trabalho para causas de valor inferior a 40 salários mínimos (convertido na Lei no 9.957/2000); PL 4694/98, que possibilitava a instituição de comissões paritárias, com representantes de empregados e de empregadores, para tentar conciliar os conflitos individuais do trabalho (transformado na Lei ${ }^{\circ}$ 9.958/2000); além dos PLs 4691, 4692 e 4695, todos de 1998, que introduziam pequenas alterações e atualizações na legislação do trabalho.

Nesse período, Noronha (2000) identificou uma lógica partidária no processo decisório na área do trabalho polarizada entre defensores do modelo legislado de relações do trabalho filiados aos partidos de esquerda, liderados pelo PT, e um grupo de deputados favoráveis a um enxugamento considerável dos direitos dos trabalhadores, vinculados aos partidos de direita, esses, por sua vez, pertencentes à base de apoio ao governo (PFLPSDB).

Segundo Diniz (2005), o Presidente Fernando Henrique apesar de não ter promovido uma reforma global do arcabouço legal foi bem-sucedido do ponto de vista da aprovação de importantes alterações incrementais na relação de emprego, tendo em vista o uso de algumas estratégias como: controle da base governista e impedimentos para que parlamentares da oposição relatassem as matérias do governo ou que tivessem suas emendas aprovadas; além da solicitação urgência para matéria de sua autoria. As propostas do Executivo contaram ainda com apoio do patronato, que se empenhou na mobilização de seus representantes no Congresso Nacional durante as votações (VOGEL, 2010). 
No que concerne aos direitos trabalhistas coletivos e à organização sindical, é crível afirmar que estes ficaram em segundo plano durante o primeiro mandato do governo FHC, tendo em vista à centralidade da agenda da desregulamentação, vista como essencial para reverter o quadro de desemprego do período. A influência dos sindicatos laborais também não conseguiu reverter esse preterimento, já que disputas internas e pressões por transformação no sindicalismo brasileiro (disputa entre o novo sindicalismo, representado pela CUT, e o sindicalismo de resultados ${ }^{15}$, retratado pela Força Sindical) acabaram consumindo as atenções e fragilizando o movimento dos trabalhadores no Brasil. Os sindicatos divergiam entre si e essa divisão impediu que sustentassem uma proposta de reforma sindical e que a inserissem na agenda de decisões.

No início do segundo mandato, porém, o governo encaminhou ao Congresso a PEC nº 623/1998, que buscava alterar em profundidade a legislação sindical brasileira ao estabelecer: fim da unicidade sindical; supressão da contribuição confederativa e sua substituição por uma contribuição negociada; revisão do poder normativo da Justiça do Trabalho; entre outras coisas. Tais mudanças, todavia, provocaram diversas críticas por grande parte das organizações sindicais. Embora atacasse de frente a unicidade e o imposto sindical, o projeto provocou a resistência até mesmo da CUT, que associou a tentativa de reforma do governo ao conjunto de suas políticas neoliberais, vendo na proposta o enfraquecimento do movimento sindical e a retirada de direitos dos trabalhadores. A Força Sindical foi a única entidade de expressão nacional que não se posicionou contrariamente à proposta, tendo em vista sua orientação voltada ao diálogo.

A proposta também não encontrou acolhida entre os sindicatos patronais, que convergiam no tocante à desregulação dos direitos trabalhistas individuais, mas que divergiam no campo dos direitos coletivos, visto que, por exemplo, boa parte do custeio das entidades patronais se dá por meio da contribuição compulsória. Assim, tendo em vista a falta de apoio necessária à aprovação da matéria, o governo parou de atuar pelo prosseguimento da proposta, que hoje encontra-se arquivada.

No começo dos anos 2000, as reformas trabalhista e sindical ainda eram temas inevitáveis no debate político em razão do contexto de aprofundamento do desemprego e da queda dos salários. Uma reforma mais ampla era pretendida pelos defensores da desregulamentação, vista como mecanismo capaz de melhorar os indicadores de emprego

\footnotetext{
${ }^{15}$ Conforme essa linha do movimento dos trabalhadores, o conflito e a confrontação deveriam abrir espaço para a concertação social entre trabalhadores e empregadores, o diálogo com o empresariado e a cooperação com o Estado.
} 
e renda. Ao mesmo tempo, no entanto, foi elevado à Presidência da República, em 2002, um candidato que vinha do movimento sindical e sobre o qual pairava a expectativa de abordar os temas da agenda trabalhista sobre uma perspectiva de fortalecimento da regulação pública.

Ciente, porém, da dificuldade de efetivar uma reforma ampla e profunda sem um processo de negociação prévia entre governo, trabalhadores e empregadores (vide a tentativa frustrada de seu antecessor quando da tramitação da PEC n ${ }^{\circ}$ 623/1998), o governo petista anunciava, desde a campanha eleitoral, que eventuais modificações na legislação trabalhista e sindical seriam precedidas por um diálogo aberto com os principais atores sociais envolvidos no mundo do trabalho. Esse debate tripartite, externo ao Congresso, teria o condão de criar um consenso em torno de propostas que pudessem ser bem-sucedidas na fase legislativa. Essa tentativa de negociação social foi, de fato, estabelecida logo no primeiro ano do mandato de Lula, por meio da instauração do Fórum Nacional do Trabalho (FNT).

No âmbito do Fórum, o governo pretendia seguir uma lógica oposta à do governo FHC e privilegiar a reforma sindical, deixando para um segundo momento a promoção de uma transformação mais profunda na legislação individual do trabalho. A reorganização da estrutura sindical foi, então, vista como um pré-requisito para que uma reforma trabalhista pudesse caminhar. Apesar dessa elevação da pauta sindical para posição de destaque na agenda não contar com a adesão do empresariado, cujo interesse político em termos trabalhistas repousa quase que exclusivamente na agenda da flexibilização, os trabalhos do FNT centraram-se na questão sindical.

Resultou das atividades do colegiado a PEC no $369 / 2005$, encaminhada pelo governo ao Congresso, que, grosso modo: acabava com a unicidade sindical; extinguia a contribuição compulsória e instituía a contribuição de negociação coletiva; previa a representação sindical nos locais de trabalho e a negociação coletiva para os servidores da Administração Pública; e incentivava a arbitragem para solução dos conflitos trabalhistas. Mesmo tendo sido construída a partir de um amplo debate, a proposta apresentada condizia mais com os interesses do próprio governo e com as preferências históricas do PT e da CUT, o que enfraqueceu a legitimidade do projeto durante sua tramitação legislativa.

O empresariado pressionou durante todo o desenrolar das atividades do FNT para que as reformas trabalhista e sindical caminhassem juntas, porém, diante da 
apresentação da PEC pelo governo e da ausência de mudanças na legislação individual do trabalho no texto, os empregadores se opuseram de forma uníssona ao projeto. As clivagens do movimento sindical que não se viam representadas na proposta, sobretudo as confederações, também promoveram uma forte resistência ao projeto do FNT dentro do Congresso. Elas propuseram, por meio do Deputado Sérgio Miranda (PCdoB/MG), o PL no 4554/2004, que basicamente visava regulamentar a Constituição Federal e manter o regime da unicidade sindical, o sistema confederativo de representação e a contribuição sindical obrigatória. Conforme Da Silva (2007: 125), tal projeto de lei não teria sido apresentado com a pretensão de ser aprovado, mas sim com o objetivo de dividir o debate e forçar um processo de negociação que aproximasse o resultado final do trâmite legislativo ao status quo.

Essa forte oposição contribuiu para o arrefecimento da tramitação da PEC $n^{\circ} 369 / 2005$. O contexto de crise política que se instaurou em 2005, diante das denúncias do "mensalão", também corroborou com a inviabilização do projeto, visto ter concentrado toda a energia do governo no período e redirecionado a atenção da mídia. Atualmente, a proposta tramita apensada à PEC no 314/2004, do Deputado Ivan Valente (PT/SP), por tratarem de assunto correlato. Elas encontram-se na Comissão de Constituição e Justiça da Câmara (CCJC), onde aguardam designação de relator desde 2013.

Com relação às alterações na legislação individual do trabalho, o governo do Presidente Luis Inácio Lula da Silva foi marcado por movimentos contraditórios. O governo não formulou uma proposta única para promover a reforma trabalhista, mas encaminhou algumas iniciativas pontuais ao Congresso Nacional que ora reforçavam a lógica da flexibilização e ora a da ampliação da regulação pública do trabalho e da proteção social. Os fundamentos neoliberais e o conservadorismo foram mais marcantes durante o exercício do primeiro mandado do Presidente. A partir de 2004, no entanto, a retomada do crescimento econômico substantivo refletiu sobre o mercado de trabalho, melhorando diversos indicadores (emprego, renda, etc.), o que acabou contribuindo para a defesa de uma agenda em favor da maior regulação pública e de proteção. Esse movimento em direção ao legislado ganha maior expressão no curso do segundo mandato do Presidente.

Indo na direção da flexibilização, foi sancionado durante o governo Lula, por exemplo, a nova lei de falências (Lei $\mathrm{n}^{\circ} 11.101 / 2005$, decorrente da aprovação do PL 4376/93, de autoria do Poder Executivo - comandado à época pelo Presidente Itamar 
Franco). Na ordem de preferência dos pagamentos que devem ser efetuados por empresas em processo falimentar, a Lei privilegiou o pagamento de credores, como bancos, em detrimento do passivo trabalhista, resultando em perdas possíveis de direitos para os trabalhadores. Para Krein, Santos e Nunes (2012), também a apresentação e sanção do Programa Nacional de Estímulo ao Primeiro Emprego pelo Executivo (Lei $\mathrm{n}^{\mathrm{o}}$ 10.748/2003) podem ser classificadas como parte da tendência à flexibilização, pois o texto prevê incentivos fiscais e redução de custos como motivadores para que as empresas contratem jovens (KREIN, SANTOS e NUNES, 2012: 10). Além dessas, outras com orientação flexibilizadora também foram propostas pelo Executivo, como a que ratifica a utilização do trabalho aos domingos pelos comerciantes varejistas, com garantia de folga de dois domingos por mês (Lei $\left.\mathrm{n}^{\circ} 11.603 / 2007\right)$.

Já na linha de maior regulação e proteção social, destaca-se a política de valorização do salário mínimo firmada em 2005 pelo Presidente Lula; o aumento do seguro-desemprego durante a crise econômico-financeira global de 2008-2009 (por meio de Resolução do Fundo de Amparo ao Trabalhador - Codefat); a sanção sem vetos do Projeto de Lei do Senado 473/03, que instituiu a nova lei do estágio (Lei no 11.788/2008); entre outras. O Executivo também encaminhou um pacote de projetos (PLs 4731/04, 4732/04, 4733/04 e 4735/04) ao Congresso Nacional que compuseram a chamada reforma processual trabalhista e que, no fim das contas, reforçavam o papel da Justiça do Trabalho como lócus prioritário da resolução dos conflitos trabalhistas, em detrimento de mecanismos como a arbitragem e a conciliação.

Também vale ressaltar a atuação do Executivo, por meio da sua base de apoio no Congresso Nacional, na retirada de pauta e na retirada de urgência em projetos, herdados do governo Fernando Henrique, que ampliavam a flexibilização. Esse foi o caso, por exemplo, do PLC 134/01, que previa a prevalência do negociado sobre o legislado. A proposta havia sido apresentada pelo governo de FHC, mas em abril de 2002, quando de sua tramitação no Senado Federal, a proposta teve sua urgência retirada por ordem do Presidente Lula. Esse caso exemplifica uma mudança de agenda, em decorrência da troca do chefe do Executivo.

Ao final do segundo mandato do Presidente Lula também não se havia operado uma reforma trabalhista global, mas expressivos avanços foram alcançados quanto à formalização, à queda da taxa de desemprego, e à recuperação dos salários. Essas 
melhorias no mercado de trabalho brasileiro, no entanto, resultaram mais do dinamismo econômico do que das medidas trabalhistas pontuais e contraditórias adotadas.

Durante o primeiro governo da Presidente Dilma Rousseff, ainda prevalecia as condições favoráveis de estruturação do mercado e das relações do trabalho. Nesse contexto, nem a reforma trabalhista nem a sindical ganharam destaque e mesmo as propostas pontuais sobre os temas foram secundárias na agenda governamental. As políticas mais relevantes encaminhas ao Congresso nessas searas foram: a que institui a política de valorização do salário mínimo (transformada na Lei $n^{\circ} 12.382 / 2011$ ); a que institui o Programa Nacional de Acesso ao Ensino Técnico e Emprego - PRONATEC (convertida na Lei $\mathrm{n}^{\circ} 12.513 / 2011$ ); e a que isenta a PLR de incidência de imposto de renda (Lei no 12.832/2013). Essas medidas, como se vê, não caminharam na direção da flexibilização dos direitos dos trabalhadores, mas na instituição deles.

Ao mesmo tempo, no entanto, algumas das principais demandas dos trabalhadores por maiores garantias e proteções sociais não avançaram durante o primeiro mandato da Presidente, como a regulamentação da terceirização, a redução da jornada de trabalho para 40 horas e o fim do fator previdenciário (visto pela classe trabalhadora como mecanismos responsável por diminuir o valor do benefício pago para quem se aposenta por tempo de serviço). Com relação a esse último tópico é importante lembrar que no início de seu segundo mandato, em junho de 2015, a Presidente vetou dispositivo que previa o fim do fator previdenciário, incluído na MP 664/14 por meio de emenda do deputado Arnaldo Faria de Sá (PTB/SP), a fim de evitar o desequilíbrio financeiro e atuarial da previdência social.

Em resumo, durante a década de 1990, especialmente durante o governo de FHC a agenda das políticas trabalhistas foi dominada pelo pensamento de orientação neoliberal que via na desregulamentação e no favorecimento dos contratos e da negociação entre as partes envolvidas na relação ao trabalho a saída para os principais problemas do mercado de trabalho no período. A questão sindical no governo Fernando Henrique foi acessória e a ausência de negociação prévia com os principais atores interessados concorreu para manutenção das características da estrutura sindical associadas ao corporativismo. Com a chegada do Presidente Lula ao poder em 2002, deuse maior vazão à defesa e à proteção do trabalhador, visto como elo fraco na relação de trabalho, e sua certificação em lei, a fim de evitar/dificultar sua remoção. A origem sindical do Presidente estimulava esse tipo de ideal, bem como estimulava as demandas 
do PT e de segmentos do "novo sindicalismo" pelo fim da unicidade sindical e da contribuição compulsória. No entanto, a reforma sindical não prosperou, tendo encontrado inúmeros pontos de veto durante sua tramitação no Congresso. Já as decisões em termos de políticas na área trabalhistas além de não serem tão significativas do ponto de vista de uma reforma, por vezes, caminharam no sentido da flexibilização. No governo de Dilma, a agenda trabalhista e sindical foi secundária e muitas vezes subordinada a agenda econômica do governo.

A retomada histórica feita nesta seção parece sustentar que as mudanças implementadas na legislação do trabalho foram graduais/incrementais. Isso ocorre, pois, os custos das reformas tendem a ser concentrados e imediatos enquanto seus benefícios são difusos, distantes no tempo e, frequentemente, incertos. Assim, aqueles que se opõem à reforma tendem a se organizar para bloqueá-la com muito mais efetividade do que aqueles que poderão dela se beneficiar no futuro. Como se viu, muitas vezes, esses oposicionistas não possuem poder de veto institucionalmente assegurado, mas são atores organizados, capazes de pressionar aqueles que o têm, como os legisladores.

No caso da reforma trabalhista (flexibilização da legislação), os principais oposicionistas, grosso modo, são os sindicatos dos trabalhadores, que veem na mudança a perda de direitos sociais adquiridos, enquanto o principal defensor é o patronato. No geral, essa reforma não avança por que seus custos eleitorais são demasiadamente altos, desestimulando os parlamentares a promovê-la, mesmo quando eles mesmos são empresários. O fato é que os benefícios alegados da flexibilização, tais como aumento do número de empregos, do dinamismo da economia e, consequentemente, dos salários podem ser evidentes apenas após longos anos, sendo difícil para os eleitores conectarem tais vantagens com a reforma prévia.

No caso da reforma sindical (eliminação das medidas que afiançam o viés corporativo da estrutura sindical), os opositores são, sobretudo, as federações e confederações sindicais, que veem na reforma um risco a sua sobrevivência, enquanto os seus patrocinadores mais relevantes são as Centrais Sindicais, especialmente a CUT. A alta conflitualidade e controvérsia das propostas de reforma têm dividido o movimento sindical e a ausência de consenso tem se refletido na arena legislativa, obstaculizando uma reforma cabal da estrutura sindical e mantendo vigentes os principais fundamentos do marco jurídico corporativista criado no período 1937-1943. 
Também foi possível perceber que o Executivo foi o principal autor de propostas de reforma ampla, no entanto, o Congresso, por meio de mecanismos institucionais diversos a sua disposição, impediu o avanço dessas propostas. O sucesso e o predomínio da agenda presidencial não são, portanto, tácitos, como poderia sustentar uma corrente da literatura que analisa as interações entre o Legislativo e o Executivo no Brasil. Eles são influenciados por uma diversidade de fatores institucionais, políticos e econômicos que estabelecem contextos específicos nos quais as decisões são tomadas e nos quais a cooperação ou o conflito por parte do Congresso são determinados. A participação do Legislativo, seja na proposição de matérias trabalhistas e sindicais, seja no engavetamento ou na modificação de propostas do Executivo será examinada em profundidade na seção analítica deste trabalho.

As perspectivas de uma reforma trabalhista exitosa parecem depender, em boa medida, de uma mudança nas relações entre o governo e os interlocutores produtivos. Diálogo aberto, via canais institucionais, e negociação prévia com os atores envolvidos parecem ser cruciais para a concretização de uma reforma mais ampla e concertada da legislação trabalhista. 


\section{4 - ASPECTOS METODOLÓGICOS}

O método de pesquisa utilizado neste trabalho é o estudo de caso. Para Yin (2015), o estudo de caso é "uma investigação empírica de um fenômeno contemporâneo dentro de seus contextos da vida real, especialmente quando os limites entre o fenômeno e o contexto não estão claramente definidos".

A pesquisa do tipo estudo de caso caracteriza-se principalmente pelo estudo em profundidade de um caso específico que merece ser investigado e pela reunião de informações numerosas e detalhadas sobre a multiplicidade de aspectos que caracterizam determinada situação. Nas palavras de Gil (1999)

\footnotetext{
"o estudo de caso é caracterizado pelo estudo profundo e exaustivo de um ou poucos objetos, de maneira a permitir conhecimentos amplos e detalhados do mesmo, tarefa praticamente impossível mediante os outros tipos de delineamentos considerados" (GIL, 1999: 73).
}

Nos estudos de caso, evidências decorrentes do exame intensivo de um caso específico contribuem para elucidar aspectos de um escopo maior de casos. Esta pesquisa assume as características de um estudo de caso, basicamente, por utilizar um caso específico (as políticas trabalhistas e sindicais) para determinar se as proposições de uma teoria são corretas.

Para tanto, são objeto desta análise os projetos de lei ordinária (PL), os projetos de emenda à Constituição (PEC) e as Medidas Provisórias (MP), de teor trabalhista e sindical, apresentados pelos deputados federais e pelo Executivo entre janeiro/2003 a dezembro/2014, bem como as proposições aprovadas. O enfoque na produção legislativa desses tipos de iniciativas deveu-se ao fato de que é por meio deles que se dão as principais alterações na legislação trabalhista do país.

Deu-se ênfase à tramitação de proposições na Câmara dos Deputados por ser esta a Casa onde os projetos de lei do Poder Executivo começam a ser apreciados e por ser esta a Casa que dispõe de maior volume de dados com fácil acesso. Além disso, é na Câmara dos Deputados onde ocorre a maioria das alterações nos textos dos projetos de lei do Executivo.

As proposições foram levantadas por meio do Sistema de Informação Legislativa (SILEG) da Câmara dos Deputados, disponível no portal da instituição na Internet (www.camara.gov.br/atividade legislativa). O levantamento foi feito com base 
na busca nas ementas ${ }^{16}$ das propostas e em suas indexações da seguinte palavra-chave: 'trabalh*'. O parâmetro * permite que a busca possa recuperar maior número de resultados. Por exemplo, ao digitar a palavra 'trabalho', o sistema irá realizar uma busca pelo termo preciso. Se, por outro lado, utilizar 'trabalh*', o asterisco possibilita a recuperação de vários outros termos, como trabalho, trabalhador, trabalhista, direito trabalhista, etc. A busca, no entanto, resultou em proposições que tratavam, por exemplo, da participação de doulas no trabalho de parto, da obrigatoriedade de instalação de telões para o acompanhamento dos trabalhos legislativos, da tipificação como crime o plágio em trabalhos acadêmicos, etc. Tais resultados não interessam ao escopo desta dissertação, por isso, as matérias passaram por um segundo filtro: despacho ao exame da Comissão Permanente de Trabalho, de Administração e Serviço Público (CTASP) no período estudado, o que caracteriza institucionalmente o vínculo da matéria com a área trabalhista e sindical.

Importante dizer que as proposições que versam sobre a legislação previdenciária foram excluídas do banco de dados para fins analíticos. Apesar da tênue relação com o direito trabalhista, acredita-se aqui que o direito previdenciário constitui um outro ramo da legislação social. Também não constam do banco de dados construído as propostas sobre da organização e remuneração dos cargos da administração federal e autárquica, pelo fato de o Executivo ter a prerrogativa exclusiva de iniciar legislação sobre esse tema (artigo 61 da Constituição Federal).

Para analisar o interesse legislativo dos parlamentares em matéria trabalhista, as proposições foram agrupadas em dezessete áreas temáticas, conforme o Anexo I. Por vezes, é difícil determinar o tema dos projetos de lei, visto que normalmente versam sobre mais de um assunto. Nesses casos, a saída encontrada foi classificar a partir do tópico mais relevante, que melhor exprime a finalidade e especificidade da proposta.

Também foram considerados os partidos políticos a que se vinculavam os parlamentares autores das proposições, a dimensão das bancadas dos partidos e a orientação político-ideológica dos partidos (direita, centro e esquerda). Levantou-se ainda a origem profissional dos deputados federias propositores. Ademais, constam do banco de dados, as seguintes variáveis: número e data de apresentação da proposta, despacho, regime de tramitação e situação de tramitação (refletindo a situação das proposições em

\footnotetext{
${ }^{16}$ As ementas dos projetos explicitam, de modo conciso, o objeto da proposta.
} 
dezembro de 2014) e data de última ação da tramitação. A variável "situação de tramitação" indica uma das seguintes situações:

\section{Quadro 2 - Situação da tramitação das proposições objeto da pesquisa}

\begin{tabular}{|c|}
\hline Situação da tramitação \\
\hline 1. Tramitando na Câmara dos Deputados \\
\hline $\begin{array}{l}\text { Apensado (arts. 139, } 142 \text { e } 143 \text { do Regimento Interno) } \\
\text { Aguardando criação de Comissão Especial } \\
\text { Aguardando deliberação de Comissão ou do Plenário } \\
\text { Aguardando designação de relator } \\
\text { Aguardando formulação de parecer }\end{array}$ \\
\hline 2. Arquivada (arts. 57, 58, 105, 133 e 146 do Regimento Interno da Câmara) \\
\hline $\begin{array}{l}\text { 3. Aguardando retorno do Senado (projeto é aprovado na } \mathrm{CD} \text { e encaminhado para a revisão } \\
\text { do SF, de acordo com o art. } 65 \text { da CF) }\end{array}$ \\
\hline 4. Transformada em norma (conversão em lei federal, sem vetos ou com vetos parciais) \\
\hline
\end{tabular}

Fonte: Quadro elaborado pela autora (2015).

Para aferição da participação dos deputados na formulação das políticas trabalhistas foram consideradas, além da proposição e aprovação das matérias de sua autoria, o bloqueio às propostas do Executivo (rejeitados, arquivados ou objetos de nãodecisão) e a reformulação/emendamento das iniciativas desse Poder. Para verificar se as proposições sofreram alteração ao longo da sua tramitação e melhor compreender as interações dos deputados com as propostas originárias do Poder Executivo, a análise empírica buscará verificar o número de iniciativas deste Poder que tiveram emendas e substitutivos de parlamentares aprovados e incorporados ao texto final.

O conteúdo dessas alterações também foi considerado e contrastado com as propostas originalmente apresentadas. Nesse quesito adota-se a metodologia desenvolvida por Freitas (2014), segundo a qual cada matéria apresentada pelo Executivo é dividida em dispositivos (artigos, parágrafos, incisos e alíneas) que são comparados a cada estrutura do projeto aprovado pelos deputados que seguiu à sanção presidencial. Assim, é possível identificar cada uma das alterações realizadas pelos deputados. As intervenções dos legisladores foram classificadas em: (1) aditivas, acrescentam novo conteúdo a um determinado projeto, ou seja, inserem artigos, incisos, parágrafos, alíneas novas; (2) modificativas, alteram o conteúdo do projeto original; e (3) supressivas, retiram 
artigos, incisos, alíneas ou parágrafos do projeto inicial. As interferências ou emendas de redação que visam apenas corrigir vícios no texto não foram consideradas modificações.

Por fim, identificou-se o autor de cada uma das alterações imprimidas, mapeando a participação de cada partido e sua posição em relação ao governo (base aliada ou oposição).

No que concerne à análise da abrangência dos projetos apresentados, a fim de responder à pergunta fundamental se a atividade legislativa dos deputados é caracterizada pela apresentação de propostas que difundem benefícios a toda a sociedade (leis nacionais) ou pela apresentação de proposições com benefícios territorialmente concentrados (leis não-nacionais de escopo reduzido), foi estabelecida um classificação, baseada em metodologias anteriores, que leva em conta o nível de agregação territorial das propostas. Assim, elas podem ser: nacionais, quando se dirigem à comunidade nacional; setorial, quando voltadas a um setor da sociedade; local (uma cidade ou município); ou individual (pode representar uma ou poucas pessoas). Destaquese que na área trabalhista/sindical existem, ainda, projetos que visam a estabelecer datas comemorativas ("institui o dia do técnico de segurança do trabalho", etc.), esses foram incluídos em uma categoria denominada "simbólico", para os quais a agregação territorial foi considerada neutra. A classificação foi feita a partir da leitura da ementa do projeto. Nos casos em que esta foi inconclusiva, a leitura do texto da proposição foi conduzida.

\section{1 - Classificação das políticas públicas}

Quando se trata de criar tipologias para as políticas públicas, a ciência política aventa como referência o ensaio clássico de Theodore Lowi (1964), quem contribuiu de maneira mais significativa com a classificação de políticas. Lowi demonstrou que existem três tipos fundamentais de políticas (e arenas decisórias): distributivas, regulatórias e redistributivas ${ }^{17}$. As primeiras decorrem de decisões tomadas pelo governo, que desconsideram a questão dos recursos limitados, gerando impactos mais individuais do que universais, ao privilegiar certos grupos sociais ou regiões, em detrimento do todo (são desagregáveis até o limite). A arena distributiva tende a não ser conflituosa, visto que

\footnotetext{
17 Após as primeiras críticas a seu trabalho, Lowi (1974) propôs mais um tipo de política: a constitutiva. Essa lida com procedimentos e tem a finalidade de alterar ou modificar as regras para a tomada de decisões públicas.
} 
interesses variados podem ser beneficiados, sendo que a concessão de benefício a um não impede a distribuição também a outro.

As políticas distributivas podem ser caracterizadas, então, pela provisão de benefícios concretos e claramente identificáveis a um grupo específico da população que sabe apontar claramente quem patrocinou a política. O distributivismo se opõe às escolhas de políticas mais gerais que afetam toda a nação ou uma grande parte dela e em muitos casos funciona como "clientelismo" e "patrimonialismo" na explicação das políticas públicas produzidas no Brasil.

O clientelismo fundamenta-se, basicamente, na troca direta entre representantes e eleitores (ou clientela), na qual o primeiro concede bens e serviços básicos aos segundos na espera de voto e apoio político futuro (ALMEIDA e LOPES, 2011: 10). Ressalte-se que a conformação do clientelismo necessita de uma assimetria de recursos e poder entre os representantes e os eleitores. Nesse contexto, os representantes têm meios para dominar e conceder os bens (por vezes a eles disponíveis em razão do cargo político que ocupam) que os eleitores não têm como alcançar por outros meios que não a troca clientelista na qual se envolvem.

A partir do momento em que o 'patrão' garante bens e serviços essenciais à sua 'clientela', essa se torna a ele ligada por um laço de lealdade e por um senso de retribuição. Esse laço, personalista (liga o eleitor diretamente ao seu representante), decorre da percepção de que o representante lhe faz um 'favor' ao prover bens privados e este ato deve ser compensado com votos.

A crítica que normalmente se faz a esse tipo de relação é que ela acaba provocando a produção/concessão de benefícios e políticas particulares e não públicos, respondendo a interesses localizados e imediatos. Mesmo quando essas políticas geram bens públicos, como a construção de uma ponte, de uma escola ou de um hospital, os seus benefícios apenas podem ser usufruídos por um município ou uma clientela específica, circunscrita geograficamente. Essa prática adquire várias manifestações como o patrimonialismo, nepotismo e casework (ALMEIDA e LOPES, 2011: 10).

Ressalte-se que políticas distributivas ou pork barrel são definidas como políticas que dispensam benefícios para uma localidade geográfica específica, difundindo os seus custos por toda a nação. Elas não envolvem uma troca direta entre o benefício recebido e uma recompensa em forma de voto ou apoio político, como nas políticas clientelistas. No entanto, é bastante provável que o apoio de políticos a propostas 
distributivas se lhes resulte em respostas positivas do eleitor, permitindo, a continuidade da barganha e o uso, ainda que indiscriminado, dos conceitos de clientelismo e distributivismo como sinônimos (BORGES, 2012: 126).

Tendo em vista essas associações, é frequente a atribuição de juízo de valor negativo às políticas distributivas, de modo que qualquer transferência concentrada de recursos é tida como indicador de disfuncionalidade do sistema. Entretanto, é preciso ressaltar que elas podem funcionar como uma referência das legítimas necessidades de populações localizadas.

As políticas regulatórias, por seu turno, direcionam-se aos grupos organizados (desagregam-se, assim, até o nível setorial). Tais arenas são conflituosas em sua essência, pois beneficiar um grupo significa impor perdas a outros.

Por seu turno, as políticas redistributivas atingem maior número de pessoas e impõe perdas concretas e no curto prazo para certos grupos sociais, e ganhos incertos e futuro para outros (SOUZA, 2006). Ademais, questionam a distribuição de poder na sociedade, remetendo a um jogo de soma zero (RICCI, 2002: 104).

Wilson (1974) também criou uma classificação de políticas bastante recorrente entre os acadêmicos da ciência política. Sua tipologia preocupa-se em identificar os custos/benefícios, que podem ser concentrados ou espalhados a partir do ponto de vista de quem carrega o ônus e de quem disfruta os bônus. Determina o grau de concentração ou dispersão das políticas o número de afetados por elas. Assim, é concentrado quando impõe custos/benefícios a grupos específicos de forma clara e difuso quando o custo/benefício é carregado por um número elevado de pessoas e não se pode identificar um grupo específico que foi atingido.

A partir dessas abordagens, Ricci (2002) desenvolveu uma estratégia própria de classificação das leis. A tipologia usada permite a análise quantitativa das políticas a partir de uma análise qualitativa de seus aspectos. São eles: generalidade, dimensão territorial e distribuição de benefícios/custos. O primeiro aspecto está relacionado com seu impacto em relação ao número de sujeitos afetados. Nesse sentido a lei pode ser geral (afeta todos os cidadãos do país), setorial/seccional (afeta uma categoria social específica, diversificada e grande), microsseccional (afeta grupos limitados, bem identificáveis) ou individual (afeta poucos ou até um só indivíduo). O segundo aspecto, relaciona-se com o 
grau dispersão/concentração das políticas e pode ser: local ou nacional ${ }^{18}$. Já o último critério procura avaliar as políticas a partir da prevalência dos custos sobre os benefícios e vice-versa ${ }^{19}$. Se os benefícios prevalecem em relação aos custos é que se pode apontar ou não o predomínio de atitudes distributivas (RICCI, 2003: 706). Os benefícios podem ser concentrados e os custos difusos, caso das políticas paroquialistas, ou os custos podem ser concentrados e os benefícios difusos, caso das políticas regulatórias, conforme tipologia de Lowi.

Lemos (2001) também desenvolveu uma tipologia para análise da produção legislativa nas questões de saúde e educação. Para a autora, as políticas podem ser observadas a partir de dois critérios: forma e escopo. A forma refere-se ao modo segundo qual o benefício é distribuído, ou seja, via regulação (da economia ou das próprias regras procedimentais) ou via transferência de renda, patrimônio ou recursos da União para o benefício de grupos, regiões e empresas (LEMOS, 2001: 571). Quanto ao escopo, as políticas podem ser classificadas em concentradas ou difusas. Concentradas quando dispensam benefícios a um indivíduo, grupo, empresa ou localidade geográfica específicos e identificáveis. Difusas quando não fazem menção direta e expressa a indivíduos, empresas, grupos ou localidades — “ou, quando o fizerem, terão em vista atenuar condições adversas econômicas" (LEMOS, 2001: 571).

Taylor e Diaz (1999), ao analisarem as leis produzidas pelo Legislativo hondurenho, também formularam uma tipologia ${ }^{20}$ que explora o nível de agregação das políticas e seus efeitos. Conforme o nível de agregação, as propostas podem ser direcionadas à comunidade nacional, a um estado ou região, a um setor da sociedade (por exemplo, a uma classe trabalhadora, ao setor bancário ou ao setor cooperativo), à

\footnotetext{
${ }^{18}$ Há quem pudesse argumentar que os dois critérios - generalidade e dimensão territorial - podem se fundir em só, tendo em vista que as leis gerais afetam o território nacional e as individuais têm consequências sobre áreas geográficas mais limitadas. O fato, no entanto, é que ao se tratar das leis setoriais a relação não é tão direta assim. A maioria dessas normas tem efeitos que estendem por todo o território nacional, porém alguma porcentagem pode ter impacto restrito, já que alguns grupos são organizados em bases territoriais (Ricci, 2002: 111).

${ }^{19}$ Esse aspecto baliza-se pela discussão empreendida por Theodore Lowi (1964), que demonstrou que existem quatro tipos fundamentais de políticas (e arenas decisórias): distributivas, regulatórias, redistributivas e constitutivas. As primeiras decorrem de decisões tomadas pelo governo, que desconsideram a questão dos recursos limitados, gerando impactos mais individuais do que universais, ao privilegiar certos grupos sociais ou regiões, em detrimento do todo. As segundas são mais visíveis ao público, envolvendo burocracia, políticos e grupos de interesse. As terceiras atingem maior número de pessoas e impõe perdas concretas e no curto prazo para certos grupos sociais, e ganhos incertos e futuro para outros. As últimas lidam com procedimentos (Souza, 2006: 28).
}

${ }^{20}$ Essa tipologia foi, mais tarde, retomada nos trabalhos de Amorim Neto e Santos (2003). 
comunidade local (uma cidade ou município) ou a um indivíduo (pode representar uma ou poucas pessoas).

Quanto aos efeitos, os autores definiram quatro categorias: benéfica, onerante, mista e neutra. Projetos benéficos são os que concedem benefícios a um indivíduo, uma prefeitura, uma região, um grupo social ou ao país como um todo. Os onerantes impõem perdas e os mistos ao mesmo tempo beneficiam algumas pessoas/grupos e oneram outras. Já os neutros não têm impacto substantivo, como as propostas comemorativas, as honoríficas e as que modificam o nome de uma rua.

Tais tipologias não determinam qual é o tipo de política desejável ou qual deve ser perseguida pelos policy makers, elas auxiliam, no entanto, na apreensão de qual tipo de política privilegiada pelos deputados federais brasileiros. Elas ajudam a desvendar quais interesses estão sendo elevados (o reduto eleitoral; grupos ou setores específicos da sociedade; ou nação), bem como a identificar quem ganha o quê e quem paga.

Para o âmbito desse trabalho a classificação dos projetos focou-se apenas no nível de abrangência ou agregação territorial das propostas, ou seja, no número de afetados pelas leis trabalhistas propostas na Câmara dos Deputados. Conforme essa tipologia, construída a partir das contribuições dos autores acima analisados, o projeto pode ser: individual, quando é direcionado a um indivíduo ou a poucos; local, quando voltado a uma localidade geográfica específica e limitada; setorial, quando endereçado a um segmento ou setor da sociedade; e nacional, quando não se vincula a nenhum grupo específico, mas atinge pessoas espalhadas por todo território nacional. Não é analisada a questão do efeito da política ou da distribuição dos custos e benefícios, visto que essa categoria tem o condão de identificar o conteúdo distributivo dos projetos e matérias trabalhistas, por sua natureza, não são distributivas, mas regulatórias e não tratam, portanto, de transferência de recursos. No Anexo III, apresenta-se um quadro que visa a fornecer alguns exemplos concretos de uma forma de classificação adequada para os propósitos deste trabalho, além de exemplos relativos a cada categoria. 


\section{5 - A TESE DO LEGISLATIVO COMO ATOR MARGINAL SOB EXAME}

Esta seção discute os principais achados da pesquisa, explorando o papel e a participação dos deputados federais na definição das políticas trabalhistas.

\section{1 - Projetos apresentados: alta proposição pelo Legislativo}

A primeira observação diz respeito à quantidade de propostas do Executivo em relação às do Legislativo em matéria trabalhista. Para o período em análise, as iniciativas do governo somam apenas 33, enquanto os projetos apresentados pelos deputados atingem o número de 1.456. É, então, expressiva a quantidade de projetos apresentados pelos parlamentares na área trabalhista. Em termos quantitativos, isso indica que o Congresso Nacional exerce um papel importante no âmbito da inicialização dos debates trabalhistas. Ademais, o número de projetos sobre o assunto vem acompanhando na mesma proporção o número total de proposições apresentadas à Câmara dos Deputados, conforme indicado no gráfico abaixo.

Gráfico 1 - Total de projetos apresentados pelos deputados à Câmara dos Deputados $x$ total de projetos de tema trabalhista apresentados pelos deputados (2003-2014)

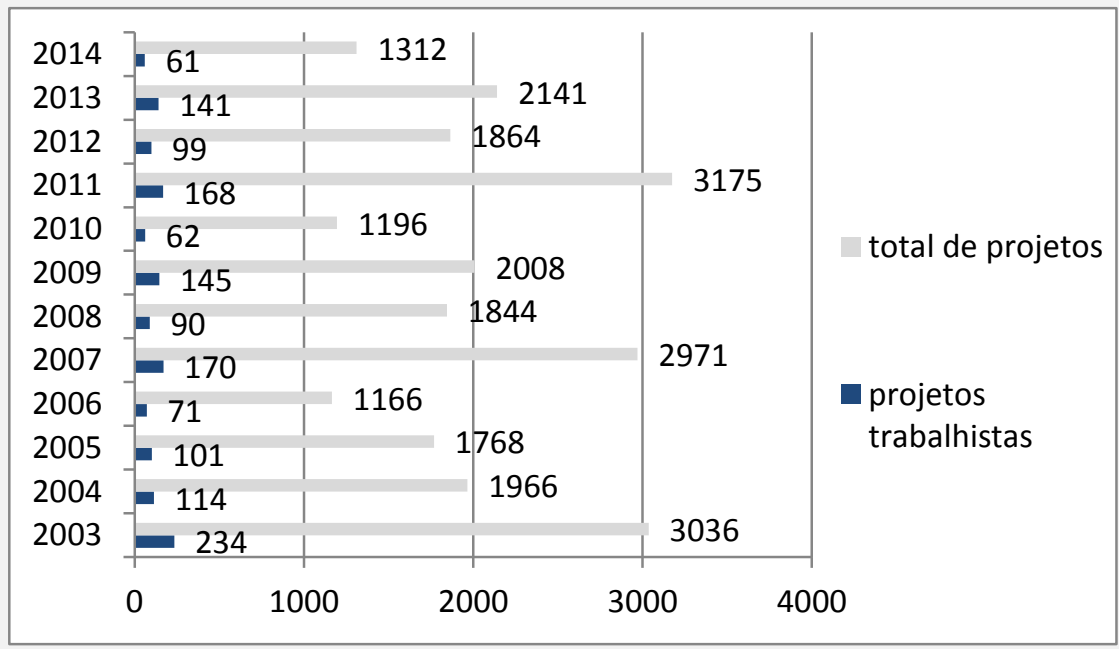

Fonte: Gráfico elaborado pela autora (2015). 
O tema trabalhista é um dos principais na agenda dos legisladores. A comparação com outros temas de política é complicada, pois não existem estudos nesse sentido para o mesmo período analisado. No entanto, o alto volume de proposições despachadas à Comissão de Trabalho, Administração e Serviço Público (CTASP) pode ser um indicador representativo da relevância das proposições de teor trabalhista. Em pesquisa sobre a organização e o funcionamento do Congresso, Figueiredo e Limongi (1996) apresentam que, entre 1989 e 1995, a CTASP foi o colegiado que recebeu o maior volume de proposições, atrás apenas da Comissão de Constituição, Justiça e Cidadania (CCJC), pela qual passam todos os projetos em tramitação na Câmara dos Deputados (FIGUEIREDO \& LIMONGI: 1996, 43).

O Gráfico 1 também permite observar que em cada uma das Legislaturas analisada os anos de eleições gerais são os de menor produtividade (2006, 2010 e 2014) quanto à proposição de leis pelos deputados, sendo os primeiros anos de cada Legislatura os mais ativos (2003, 2007 e 2011). A mesma tendência é observada no caso dos projetos que versam sobre tema trabalhista. Os deputados apresentam menor volume de propostas em anos de eleições gerais, pois nesse período os parlamentares despendem mais tempo e energia com suas campanhas, e não se dedicam tanto ao trabalho legislativo. "O ano eleitoral é ano de 'corpo a corpo' com o eleitor, não é tempo de se começar a produzir propostas" (Lemos, 2001:13).

Além disso, para que se possa colher os benefícios das propostas no ano das eleições, afim de que elas sejam possivelmente convertidas em votos, é preciso que elas sejam apresentadas bem antes das eleições, para que os parlamentares tenham tempo de construir sua imagem a partir delas, e mais ainda, para que os eleitores possam associálas a seus proponentes, o que não acontece imediata e automaticamente.

Também se percebe, de maneira geral, uma diminuição no número de projetos propostos nos anos em que ocorrem as eleições municipais (2004, 2008 e 2012), que acontecem dois anos depois dos pleitos para preenchimento dos cargos eletivos nos níveis federal e estadual. A proposição na área trabalhista, também acompanha essa tendência. A explicação encontra-se no fato de que muitos deputados federais resolvem concorrer a cargos de prefeito e vereador e, por consequência, interessados em aumentar sua chance de sucesso eleitoral, passam a se dedicar a suas campanhas e relegam a atividade legislativa a segundo plano. 
O evento das eleições, como se vê, compromete a apresentação de projetos e os trabalhos legislativos como um todo. Já os anos após as eleições para muitos representantes, especialmente para os que estão em seu primeiro ano de mandato, é uma oportunidade de mostrar aos eleitores suas posições e de cumprir as promessas de campanha e compromissos para os quais foi eleito. Isso pode justificar o fato de serem os primeiros anos de cada uma das Legislaturas analisadas os mais produtivos em termos de projetos de lei propostos. Dessa forma, percebe-se que o número de projetos apresentados, inclusive na área trabalhista, segue movimentos ondulatórios, com vales em anos eleitorais (tanto em períodos de eleições gerais, quanto municipais) e picos nos anos imediatamente seguintes.

Importante destacar que os deputados federais brasileiros podem apresentar uma infinidade de propostas durante o exercício de seu mandato, já que praticamente inexistem custos envolvidos nessa etapa do trabalho legislativo e também inexistem restrições formais ao volume de proposições por parlamentar. Mesmo sabendo que a quase totalidade dessas proposições não serão convertidas em lei, a apresentação de projetos constituiria um dos instrumentos da estratégia de reeleição, na medida em que permitiria ao parlamentar efetuar a accountability (prestação de contas) ao eleitorado, a ele sinalizar que está tentando satisfazer seus interesses e realizar as promessas para as quais foi eleito (ARAÚJO, 2008: 212), além de se posicionar a respeito de temas do interesse de seus eleitores. Para Ricci (2003) a maioria dos projetos apresentados pelos deputados seriam "propostas-bandeiras", isto é, projetos de lei que já se sabe que nunca serão aprovados ou debatidos, mas que servem para sinalizar aos eleitores do parlamentar autor o seu comprometimento com determinada causa ou demanda.

A apresentação de projetos de lei pode ser um importante parâmetro do qual dispõe os eleitores para julgar e avaliar retrospectivamente a participação e o desempenho do seu candidato no Congresso, podendo esta ser uma variável a ser levada em conta no momento da decisão do voto. De um modo geral, os eleitores não monitoram de perto os trabalhos de um parlamentar, mas o avaliam a partir de alguns aspectos que durante o mandato conseguiram de alguma maneira chamar a sua atenção (NICOLAU, 2002: 225). Nesse sentido, podemos especular sobre a importância da apresentação elevada de projetos como uma das atividades legislativas fiadoras da visibilidade do parlamentar no decorrer do seu mandato. 
Inclusive, durante anos eleitorais, diversos meios de comunicação costumam divulgar uma espécie de ranking dos deputados mais produtivos durante o mandato, associando a eles uma imagem positiva, de parlamentar comprometido com os eleitores e acima de tudo de parlamentar que trabalha. Os próprios parlamentares também divulgam seus números como estratégia para favorecer sua imagem frente aos eleitores e criar um estereótipo correspondente ao ideal de representante do eleitor ou ainda um estereótipo de parlamentar formulador, que por meio dos textos das proposições por eles elaboradas inserem assuntos na agenda de discussões do Congresso.

Com relação aos partidos por trás das proposições introduzidas pelos deputados federais brasileiros, temos que o PT, seguido pelo PMDB, pelo PSDB, PFL e PSB, respectivamente, foi o partido cujos parlamentares mais propuseram projetos trabalhistas em números absolutos, conforme é possível observar no Gráfico 3 a seguir.

\section{Gráfico 2 - Distribuição dos projetos trabalhistas apresentados entre 2003 e 2014 pelos deputados federais, conforme a origem partidária}

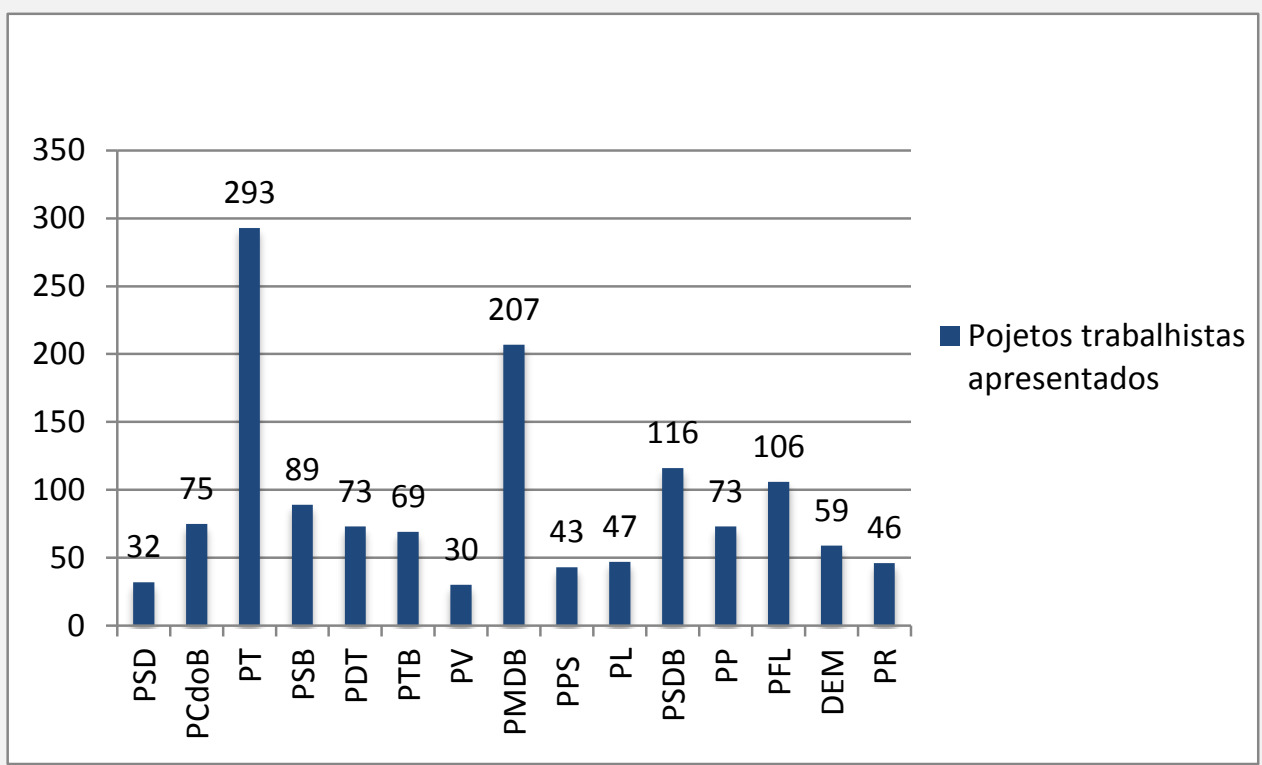

Fonte: Gráfico elaborado pela autora (2014).

* Partidos que propuseram projetos de teor trabalhista em quantidade $\leq$ a 30 foram omitidos do gráfico. São eles: PSC, PRB, PSOL, PMN, PROS, PTdoB, PPB, PRTB, PSL, PTC, PHS, PAN, PRONA, PRP e PSDC. Esses partidos em conjunto apresentaram um total de 100 projetos ao longo de todo o período analisado (2003-2014).

** O Partido da Frente Liberal (PFL) alterou sua denominação para Democratas (DEM) no ano de 2007.

*** O PR foi criado em 2006 após a fusão do PL com o PRONA. 
No entanto, se dividirmos o número de projetos apresentados por cada partido pelo tamanho médio de suas respectivas bancadas nas três Legislaturas examinadas, a situação se altera, conforme o Quadro 3 permite observar.

Quadro 3 - Distribuição dos projetos trabalhistas apresentados entre 2003 e 2014 pelos deputados federais, segundo a origem partidária (tamanho da bancada na eleição)

\begin{tabular}{|c|c|c|c|c|c|c|c|c|c|}
\hline \multirow[t]{3}{*}{ Partidos } & \multicolumn{9}{|c|}{$\begin{array}{l}\mathrm{X}=\text { Número de projetos trabalhistas apresentados } \\
\mathrm{Y}=\text { Tamanho da bancada na eleição } \\
\mathrm{Z}=\mathrm{X} / \mathrm{Y}\end{array}$} \\
\hline & \multicolumn{3}{|c|}{$52^{a}$ Legislatura (2003-2006) } & \multicolumn{3}{|c|}{$53^{a}$ legislatura (2007-2010) } & \multicolumn{3}{|c|}{ 54 ${ }^{\text {a }}$ legislatura (2011-2014) } \\
\hline & $\mathrm{X}$ & $\mathrm{Y}$ & $\mathrm{Z}$ & $X$ & $\mathrm{Y}$ & $\mathrm{Z}$ & $\mathrm{X}$ & $\mathrm{Y}$ & $\mathrm{Z}$ \\
\hline PSD & 0 & 0 & 0 & 0 & 0 & 0 & 32 & 4 & 8 \\
\hline PCdoB & 14 & 12 & 1,166 & 35 & 13 & 2,692 & 26 & 15 & 1,733 \\
\hline DEM & 0 & 0 & 0 & 28 & 43 & 0,651 & 31 & 21 & 1,476 \\
\hline PPS & 25 & 15 & 1,666 & 10 & 22 & 0,454 & 8 & 12 & 0,666 \\
\hline PT & 143 & 91 & 1,571 & 77 & 83 & 0,927 & 73 & 86 & 0,848 \\
\hline $\mathrm{PL} / \mathrm{PR}$ & 47 & 26 & 1,807 & 15 & 34 & 0,441 & 28 & 40 & 0,7 \\
\hline PSB & 13 & 22 & 0,590 & 42 & 27 & 1,555 & 34 & 35 & 0,971 \\
\hline PDT & 24 & 21 & 1,142 & 24 & 24 & 1 & 25 & 27 & 0,925 \\
\hline PTB & 43 & 26 & 1,653 & 18 & 22 & 0,818 & 8 & 22 & 0,363 \\
\hline PV & 3 & 5 & 0,6 & 13 & 13 & 1 & 14 & 13 & 1,076 \\
\hline PP & 27 & 49 & 0,551 & 21 & 41 & 0,512 & 25 & 44 & 0,568 \\
\hline PMDB & 34 & 75 & 0,453 & 89 & 89 & 1 & 84 & 78 & 1,076 \\
\hline PFL & 102 & 84 & 1,214 & 5 & 65 & 0,076 & 0 & 0 & 0 \\
\hline PSDB & 36 & 70 & 0,514 & 47 & 66 & 0,712 & 33 & 54 & 0,611 \\
\hline $\begin{array}{l}\text { Total de } \\
\text { proposiç̃es }\end{array}$ & \multicolumn{3}{|c|}{511} & \multicolumn{3}{|c|}{424} & \multicolumn{3}{|c|}{421} \\
\hline
\end{tabular}

Fonte: Quadro elaborado pela autora (2014).

* Partidos que propuseram projetos de teor trabalhista em quantidade $\leq$ a 30 foram omitidos do gráfico. São eles: PSC, PRB, PSOL, PMN, PROS, PTdoB, PPB, PRTB, PSL, PTC, PHS, PAN, PRONA, PRP e PSDC. Esses partidos em conjunto apresentaram um total de 100 projetos ao longo de todo o período analisado (2003-2014).

** O Partido da Frente Liberal (PFL) alterou sua denominação para Democratas (DEM) no ano de 2007.

*** O PR foi criado em 2006 após a fusão do PL com o PRONA.

Percebe-se, assim, que na $52^{\mathrm{a}}$ legislatura, se destacam como cinco primeiros propositores de matérias trabalhistas, respectivamente: PL/PR, PPS, PTB, PT e PFL. Na 53 $3^{\mathrm{a}}$ Legislatura: PCdoB, PSB, PDT, PV e PMDB. E na 54: PSD, PCdoB, DEM, PV e PMDB. Essas variações deixam evidente que o tamanho da bancada não guarda relação com a proporção de proposições trabalhistas apresentadas por seus membros. 
Se analisarmos o número de projetos trabalhistas apresentados a partir da orientação política e ideológica do partido dos seus autores, porém, é possível traçar uma relação. Há uma vasta literatura sobre a classificação ideológica dos partidos políticos brasileiros, na qual se encontram muitas discordâncias ${ }^{21}$. A adotada neste estudo é a simplificada (possui três posições), baseada nas classificações formuladas nos estudos de Kinzo (1990), Carvalho (2003) e Carreirão (2006), cuja a definição operacional no eixo direita-esquerda é: (1) Direita - PFL/DEM, PTB, PL/PR, PP e PSD; (2) Centro - PMDB e PSDB; (3) Esquerda - PT, PDT, PSB, PPS, PCdoB e PV.

Conforme essa classificação, temos que os partidos de orientação mais à esquerda do espectro político-ideológico, proporcionalmente ao tamanho de suas bancadas, são os maiores propositores de matérias na seara trabalhista em todas as legislaturas analisadas, como mostra o Quadro 4.

\section{Quadro 4 - Distribuição dos projetos trabalhistas apresentados entre 2003 e 2014 pelos deputados federais, conforme orientação ideológica do partido}

\begin{tabular}{|c|c|c|c|c|c|c|c|c|c|c|}
\hline \multirow[t]{3}{*}{ Partidos } & \multicolumn{9}{|c|}{$\begin{array}{c}\mathrm{X} \text { = Número de projetos trabalhistas apresentados } \\
\text { Y = Tamanho da bancada na eleição } \mathrm{Z}=\mathrm{X} / \mathrm{Y}\end{array}$} & \multirow[t]{3}{*}{$\begin{array}{l}\text { Total de } \\
\text { projetos }\end{array}$} \\
\hline & \multicolumn{3}{|c|}{$\begin{array}{c}52^{\mathrm{a}} \text { Legislatura } \\
(2003-2006)\end{array}$} & \multicolumn{3}{|c|}{$\begin{array}{c}53^{\mathrm{a}} \text { legislatura } \\
(2007-2010)\end{array}$} & \multicolumn{3}{|c|}{$\begin{array}{c}\text { 54 }{ }^{\mathrm{a}} \text { legislatura } \\
(2011-2014)\end{array}$} & \\
\hline & $\mathrm{X}$ & $Y$ & $\mathrm{Z}$ & $X$ & $\mathrm{Y}$ & $\mathrm{Z}$ & $X$ & $\mathrm{Y}$ & $\mathrm{Z}$ & \\
\hline Direita & 219 & 185 & 1,18 & 87 & 205 & 0,42 & 124 & 131 & 0,94 & 430 \\
\hline Esquerda & 222 & 166 & 1,33 & 201 & 182 & 1,10 & 180 & 102 & 1,76 & 603 \\
\hline Centro & 70 & 145 & 0,48 & 136 & 155 & 0,87 & 117 & 132 & 0,88 & 323 \\
\hline
\end{tabular}

Fonte: Quadro elaborado pela autora (2015).

* Outros partidos também propuseram projetos de teor trabalhista. Eles foram, no entanto, omitidos do quadro visto terem apresentado quantidade $\leq$ a 30. São eles: PSC, PRB, PSOL, PMN, PROS, PTdoB, PPB, PRTB, PSL, PTC, PHS, PAN, PRONA, PRP e PSDC. Esses partidos em conjunto apresentaram um total de 100 projetos ao longo de todo o período analisado (2003-2014). Importante ter em conta, ainda, que boa parte desses partidos podem ser considerados como "indefinidos" ideologicamente por insuficiência de informações.

\footnotetext{
${ }^{21}$ Importante notar que o senso comum e os meios de comunicação, muitas vezes, consideram os partidos políticos brasileiros indistintos do ponto de vista ideológico. Esse diagnóstico fundamenta-se na ocorrência de coligações eleitorais ou coalizões governamentais "esdrúxulas" ou inconsistentes, que abrangem partidos de matrizes ideológicas diferentes, e na alta taxa de migração de políticos entre partidos. Não obstante essa tese, estudos na ciência política, baseados na diferenciação ideológica, têm sustentado a utilidade desse critério para compreensão da atuação dos partidos no Brasil.
} 
Essa maior preferência entre os partidos da esquerda por projetos trabalhistas pode estar relacionada com a composição de seu eleitorado. Boa parte dos parlamentares egressos de partidos de orientação mais à esquerda é eleita por votos de segmentos sociais (grupos étnicos, trabalhadores, etc.) e setores de opinião, que ensejam uma representação ideologicamente orientada, que priorize a defesa de temas, especialmente aqueles com forte carga ideológica. Ou seja, um desempenho legislativo compatível com a aquilo que Mayhew (2004) denomina "position taking”, que enfatiza a vocalização de posição e a defesa de determinado tema em debate no Congresso ou na sociedade, além da publicização da posição tomada em relação a esses assuntos. Dentre as atividades legislativas comumente desempenhadas por deputados de esquerda, a iniciativa de leis, juntamente com as votações em Plenário (CARVALHO, 2003:159), figura como recurso importante de vinculação de posicionamento sobre questões.

Apresentaram projetos trabalhistas no período 507 diferentes deputados federais. Destes, a maioria $(51,6 \%)$ atuou na CTASP, seja na qualidade de titular, seja de suplente. Ademais, $38 \%$ deles tem experiência prévia ou afinidade temática com a área trabalhista determinada ou pela sua história pessoal, ou pela sua origem socioprofissional ou pelos vínculos que possuem, por vezes até anteriores ao ingresso na carreira política, com organizações sindicais dos trabalhadores ${ }^{22}$.

Vale ressaltar que as eleições de 2002 representaram um momento importante na trajetória de ocupação de representantes sindicais em postos importantes da gestão do Estado. Na Câmara dos Deputados, o número de (ex) sindicalistas aumentou 36,6\% em relação ao período anterior (1999-2002), conforme dados do Departamento Intersindical de Assessoria Parlamentar (DIAP, 2014). Ademais, 44 dos 91 deputados federais eleitos pelo PT tinham origem no movimento sindical (LUCCA, 2011).

Outra categoria que se destacou na proposição de matérias trabalhistas foi a dos parlamentares empresários ${ }^{23}$. Esses congressistas foram responsáveis por $16 \%$ dos

\footnotetext{
${ }^{22}$ Para se ter uma ideia, muitos dos parlamentares autores de projetos na área trabalhista foram sindicalistas (caso dos deputados Marco Maia, Chico Alencar e Luciana Genro, por exemplo), dirigentes de entidades sindicais importantes como a CUT e a União Geral dos Trabalhadores (caso dos deputados Vicentinho e Ademir Camilo), fundadores dos sindicatos de suas respectivas categorias profissionais (como os deputados João Dado e Dr. Rosinha), advogados trabalhistas (como a deputada Dra. Clair), advogado de sindicato (caso do Deputado Nelson Pelegrino), entre outros. Essas informações foram obtidas e organizadas a partir do repositório biográfico, disponibilizado pela Câmara dos Deputados em seu sítio na Internet: http://www2.camara.leg.br/deputados/pesquisa

${ }^{23}$ Consideram-se empresários os parlamentares que sejam proprietários ou sócios de algum estabelecimento comercial, industrial, de prestação de serviços ou ainda proprietário de fazenda ou de indústria agropecuária.
} 
projetos iniciados no período. Apesar dessa 'bancada informal' ser maior do que a bancada de sindicalistas na Câmara dos Deputados, como se observa no Quadro 5, eles foram menos atuantes em termos de iniciação de projetos de teor trabalhista.

\section{Deputados}

\section{Quadro 5 - Representação sindical x empresarial na Câmara dos}

\begin{tabular}{|l|c|c|c|c|}
\hline \multirow{2}{*}{$\begin{array}{c}\text { Bancada } \\
\text { Informal }\end{array}$} & \multicolumn{3}{|c|}{ Legislatura } & \multirow{2}{*}{ Média } \\
\cline { 2 - 5 } & $\begin{array}{c}\mathbf{5 2}^{\text {a }} \text { legislatura } \\
(\mathbf{2 0 0 3 - 2 0 0 6 )}\end{array}$ & $\begin{array}{c}\mathbf{5 3}^{\text {a }} \text { legislatura } \\
(\mathbf{2 0 0 7 - 2 0 1 0 )}\end{array}$ & $\begin{array}{c}\mathbf{5 4}^{\text {a }} \text { legislatura } \\
(\mathbf{2 0 1 1 - 2 0 1 4 )}\end{array}$ & \\
\hline Sindical & 60 & 60 & 72 & 64 \\
\hline Empresarial & 102 & 120 & 273 & 165 \\
\hline
\end{tabular}

Fonte: Diap, 2014.

Os demais projetos foram apresentados por parlamentares de outras origens profissionais como advogados (9\%), administradores de empresa (6\%), radialistas $(6 \%)$, entre vários outros.

Conforme Ricci e Lemos (2004) essa expertise prévia pode servir como sinalizadora das redes de apoio dos parlamentares, suas fontes prováveis de financiamento de campanha, de interlocução e de informação dentro do Congresso. Ademais, indicam que a análise da conexão eleitoral unicamente como função da relação entre políticos e eleitores (dentro dos distritos) não contempla toda a complexidade do processo legislativo, já que a representação se faz não só do ponto de vista geográfico, mas também dos interesses organizados. A atuação dos grupos de interesse, as atividades de lobby e a influência dos setores organizados da sociedade - especificamente sindicatos, para o caso de projetos trabalhistas - impactam a dinâmica legislativa e o policymaking.

Em relação ao padrão de apresentação de projetos pelo Executivo no período objeto desta análise, o Gráfico 3, abaixo, revela que a iniciativa deste Poder é bem mais comedida do que a do Legislativo. O período de 2003 a 2006 (52 ${ }^{\text {a }}$ Legislatura), que condiz com o primeiro exercício do mandato do Presidente Luís Inácio Lula da Silva, foi o mais produtivo em termos de proposição de matérias trabalhistas. Ao longo das demais Legislaturas, o interesse do executivo por essa área de política foi decrescendo. 
Gráfico 3 - Total de projetos apresentados pelo Executivo $x$ total de projetos de tema trabalhista apresentados pelo Executivo (2003-2014)

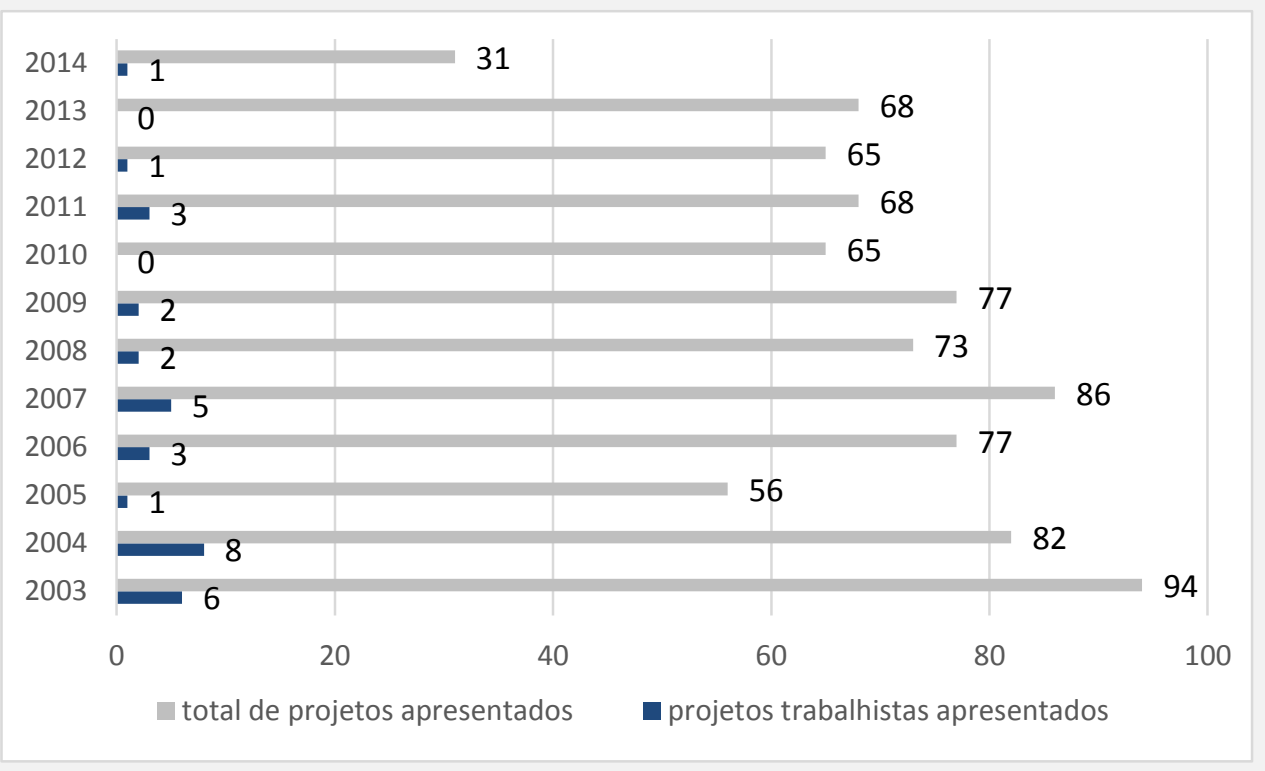

Fonte: Gráfico elaborado pela autora (2015).

Como anteriormente discutido, o debate sobre as questões trabalhistas/sindicais no governo do Presidente Fernando Henrique Cardoso foi dominado pelo pensamento de orientação neoliberal que privilegiou a flexibilização das relações trabalhistas, tendo importante repercussão sobre as políticas discutidas e formuladas no Congresso Nacional e inviabilizando iniciativas em defesa do trabalho regulado. Se isso faz sentido, então a chegada do Presidente Lula ao poder em 2003 deve ser pensada como momento oportuno para proposição de projetos no campo trabalhista que vinham sendo nutridos ao longo do processo histórico que reprimiu as alternativas do trabalho regulado.

Conforme o Gráfico 3, ainda, é possível afirmar que ciclo eleitoral não exerce influência no nível de apresentação de propostas pelo Executivo, refletindo as diferenças nas conexões eleitorais de ambos os Poderes e também o fato de que o sistema oferece ao Executivo instrumentos que funcionam regularmente (GOMES, 2011).

O Quadro 6, a seguir, apresenta a autoria por tipo de proposição. Das 33 propostas iniciadas pelo Executivo no período, 10 foram Medidas Provisórias. A maioria delas (5) foi enviada ao Congresso no primeiro governo do Presidente Luis Inácio Lula da Silva. No segundo mandato, foram duas MPs e, durante o governo da Presidente Dilma Rousseff, iniciaram tramitação na Câmara três MPs. O Executivo apresentou apenas uma Proposta de Emenda à Constituição (PEC no 369/2005), introduzida pelo Presidente Lula 
com o intuito de concretizar a reforma sindical. Em contraposição, o Legislativo apresentou 45 propostas de alteração da Constituição Federal. É importante ter em conta que tentativas de promover alterações nos textos constitucionais são presumidamente eventos de vulto para o sistema político nacional.

\section{Quadro 6 - Tipo de proposição, por origem (2003-2014)}

\begin{tabular}{|l|c|c|}
\hline \multicolumn{1}{|c|}{ Tipo de proposição apresentada } & Executivo & Legislativo \\
\hline Medida Provisória (MP) & 10 & - \\
\hline Projeto de lei ordinária (PL) & 22 & 1.411 \\
\hline Proposta de Emenda à Constituição (PEC) & 1 & 45 \\
\hline Total & $\mathbf{3 3}$ & $\mathbf{1 . 4 5 6}$ \\
\hline
\end{tabular}

Fonte: Elaborado pela autora (2015).

Outro aspecto importante referente à análise das proposições trabalhistas apresentadas, diz respeito ao assunto abordado em cada proposta. Todos os 1.489 projetos foram classificados em dezessete categorias, às quais foi acrescentada uma categoria residual denominada "outros" (alguns exemplos de projetos que se enquadram em cada categoria são apresentados no Anexo I). Conforme o Quadro 7, apresentado abaixo, é possível perceber que a agenda de propostas protocoladas pelos deputados federais abrange quase todos os campos da relação de trabalho. 


\section{Quadro 7- Conteúdo dos projetos trabalhistas apresentados na Câmara dos Deputados (2003-2014)}

\begin{tabular}{|c|c|c|c|}
\hline Área temática & Legislativo & Executivo & Total \\
\hline Benefícios sociais & 66 & 2 & 68 \\
\hline Demissão e rescisão de contrato/estabilidade & 82 & - & 82 \\
\hline Apoio ao desempregado/seguro-desemprego & 68 & 1 & 69 \\
\hline Situações de afastamento/licenças & 87 & 2 & 89 \\
\hline Homenagens e datas comemorativas & 21 & 1 & 22 \\
\hline Discriminação no mercado de trabalho & 48 & - & 48 \\
\hline Duração do trabalho & 124 & 1 & 125 \\
\hline Processos judiciais trabalhistas & 124 & 7 & 131 \\
\hline Modalidade de contratos & 94 & 3 & 97 \\
\hline Negociação coletiva/acordos e convenções & 36 & - & 36 \\
\hline Organização sindical e contribuição & 56 & 3 & 59 \\
\hline Política salarial & 62 & 3 & 65 \\
\hline Regulamentação de profissões & 130 & - & 130 \\
\hline Segurança e saúde no trabalho & 162 & 1 & 163 \\
\hline $\begin{array}{llll}\text { Direitos humanos/trabalho escravo ou } \\
\text { degradante }\end{array}$ & 53 & 1 & 54 \\
\hline Tributação & 64 & 1 & 65 \\
\hline Inclusão/inserção no mercado de trabalho & 50 & 4 & 54 \\
\hline Qualificação do trabalhador & 32 & 1 & 33 \\
\hline Terceirização & 20 & - & 20 \\
\hline Outros* & 77 & 2 & 79 \\
\hline Total & 1.456 & 33 & 1.489 \\
\hline
\end{tabular}

Fonte: elaborado pela autora (2015).

* Enquadram-se nessa categoria os projetos que versam sobre: administração pública (13), cooperativas de trabalho (12), direito de greve (6), FGTS (17), carteira de trabalho (10), participação nos lucros (7) e férias (14).

A maioria dos projetos de autoria parlamentar versaram sobre segurança e saúde no trabalho $(11,2 \%)$, processos judiciais trabalhistas $(9 \%)$, regulamentação de profissões $(8,9 \%)$ e duração de trabalho $(8,5 \%)$. Importante frisar o peso dos projetos que propõem a regulamentação das profissões de categorias específicas na agenda do Legislativo, superando, por exemplo, aquelas que tratam sobre questões salariais e que estabelecem regras para admissão e demissão. Propostas sobre esse tema, geralmente, 
resultam de demandas e pressões das categorias a serem regulamentadas (historiadores, DJs, cuidadores de idoso, perito judicial, aculputurista, etc.)

No âmbito da iniciativa do Executivo, há uma preponderância de projetos sobre processos judiciais trabalhistas $(21,2 \%)$ e inclusão no mercado de trabalho $(12,2 \%)$. Importante destacar que o elevado número de projetos sobre processos judiciais trabalhistas entre as inciativas do Executivo deve-se ao envio pelo governo do Presidente Lula ao Congresso Nacional de um pacote de propostas destinadas a promover a reforma processual trabalhista (PLs ${ }^{\circ}$ s 4.731/2004, 4.732/2004, 4.733/2004 e 4.735/2004).

No que concerne especificamente às MPs, estas se concentraram majoritariamente (40\%) no tema inclusão no mercado de trabalho (inclusão de jovens, mais especificamente). Editadas durante o primeiro governo Lula, essas MPs sintetizavam o esforço do governo para reduzir da taxa de desemprego e aumentar o número de empregos formais no país. Quanto às PECs, estas foram mais dirigidas aos assuntos de inclusão no mercado de trabalho $(17,4 \%)$, a fim de reduzir a idade mínima para o trabalho para 14 anos, e processos judiciais trabalhistas (13\%).

No geral, olhando para o conjunto das proposições que cada Poder procurou colocar em pauta, não é possível assegurar que o Legislativo tenda a propor, dentro do universo de temas trabalhistas, assuntos muito diferentes daqueles iniciados pelo Executivo. O mesmo se verifica em relação ao que foi aprovado. Assim, a tese de uma agenda legislativa composta por questões muito distintas e conflitantes entre os Poderes não se verifica no caso específico desta área de políticas.

Com relação à distribuição temática dos projetos dos deputados federais, conforme orientação ideológica do partido de seus autores, verifica-se a predominância da esquerda em quase todas as categorias temáticas, como mostra o Quadro 8. Essa predominância também pode ser percebida quando levada em conta o tamanho da bancada (vide Anexo II). No geral, prevaleceram entre as iniciativas da esquerda a inicialização de projetos que tratam da saúde e segurança do trabalho, da regulamentação de profissões e duração do trabalho de certas categorias profissionais. 
Quadro 8- Distribuição dos temas dos projetos trabalhistas apresentados entre 2003 e 2014 pelos deputados federais, conforme orientação ideológica do partido

\begin{tabular}{|l|c|c|c|}
\hline \multirow{2}{*}{ Área temática } & \multicolumn{2}{c|}{ Orientação ideológica do partido } \\
\cline { 2 - 4 } & Centro & Direita & Esquerda \\
\hline Modalidade de contratos & $22(23,5 \%)$ & $34(36,2 \%)$ & $34(36,2 \%)$ \\
\hline Inclusão no mercado de trabalho & $10(20 \%)$ & $23(46 \%)$ & $15(30 \%)$ \\
\hline Terceirização & $5(25 \%)$ & $2(10 \%)$ & $11(55 \%)$ \\
\hline Política salarial & $15(24,2 \%)$ & $17(27,5 \%)$ & $28(45,2 \%)$ \\
\hline Justiça do Trabalho & $36(29 \%)$ & $40(32,2 \%)$ & $42(34 \%)$ \\
\hline Demissão e rescisão de contrato/estabilidade & $22(27 \%)$ & $19(23,2 \%)$ & $30(36,6 \%)$ \\
\hline Regulamentação de profissões & $26(20 \%)$ & $32(24,6 \%)$ & $62(47,7 \%)$ \\
\hline Segurança e saúde no trabalho & $33(20,4 \%)$ & $44(27,2 \%)$ & $78(48,2 \%)$ \\
\hline Direitos humanos/trabalho escravo ou degradante & $8(15,1 \%)$ & $17(32,1 \%)$ & $28(53 \%)$ \\
\hline Apoio ao desempregado/seguro-desemprego & $19(28 \%)$ & $21(31 \%)$ & $19(28 \%)$ \\
\hline Situações de afastamento/licenças & $26(30 \%)$ & $25(29 \%)$ & $32(37 \%)$ \\
\hline Discriminação no mercado de trabalho & $8(16,5 \%)$ & $11(23 \%)$ & $23(48 \%)$ \\
\hline Duração do trabalho & $22(17,8 \%)$ & $34(27,5 \%)$ & $62(50 \%)$ \\
\hline Negociação coletiva/acordos e convenções & $7(19,5 \%)$ & $13(36,2 \%)$ & $15(41,5 \%)$ \\
\hline Organização sindical e contribuição & $7(12,5 \%)$ & $14(25 \%)$ & $31(55,5 \%)$ \\
\hline Qualificação do trabalhador & $9(28,2 \%)$ & $8(25 \%)$ & $17(53,2 \%)$ \\
\hline Benefícios sociais & $13(19,7 \%)$ & $23(35 \%)$ & $10(15,2 \%)$ \\
\hline Homenagens e datas comemorativas & $3(14,3 \%)$ & $7(33,4 \%)$ & $9(43 \%)$ \\
\hline Tributação & $16(25 \%)$ & $20(31,2 \%)$ & $22(34,5 \%)$ \\
\hline Outros* $16(20,8 \%)$ & $23(30 \%)$ & $35(45,5 \%$ \\
\hline Total & 323 & 430 & 603 \\
\hline
\end{tabular}

Fonte: elaborado pela autora (2015).

* Enquadram-se nessa categoria os projetos que versam sobre: administração pública (13), cooperativas de trabalho (12), direito de greve (6), FGTS (17), carteira de trabalho (10), participação nos lucros (7) e férias (14).

** Partidos que propuseram projetos de teor trabalhista em quantidade $\leq$ a 30 foram omitidos do quadro. São eles: PSC, PRB, PSOL, PMN, PROS, PTdoB, PPB, PRTB, PSL, PTC, PHS, PAN, PRONA, PRP e PSDC. Esses partidos em conjunto apresentaram um total de 100 projetos ao longo de todo o período analisado (2003-2014). Importante ter em conta, ainda, que boa parte desses partidos podem ser considerados como "indefinidos" ideologicamente por insuficiência de informações.

No geral, as discussões sobre a legislação trabalhista no Brasil, tendem a polarizar-se em dois extremos: (1) aqueles que defendem a flexibilização da lei, para permitir que contratos de trabalho sejam negociados entre trabalhadores e empregadores, 
respeitando às especificidades de cada setor da economia, ou empresa; e (2) aqueles que buscam criar obrigações legais detalhadas, a fim de proteger os trabalhadores, visto como polo frágil da relação trabalhista, e, assim, evitar a precarização e exploração do trabalho. Há argumentos fortes dos dois lados, no entanto, como já afirmado, a tradição brasileira ainda privilegia a rigidez legal. No Congresso, essa preponderância é evidente no período analisado.

Se agruparmos os projetos apresentados em dois conjuntos - tarefa difícil, já que a classificação nesses dois clusters enseja uma leitura atenta dos dispositivos das propostas e compreensão das suas intenções gerais - excluídos aqueles que estabelecem homenagens e datas comemorativas - é possível assegurar que pelo menos 63\% (942 proposições) dos projetos trabalhistas em tramitação no período estudado vão no sentido da maior regulação e rigidez da norma, a fim de fixarem mais direitos e garantias em lei. A maioria dos projetos apresentados criam mais deveres para os empregadores (contratação de seguro de vida para os empregados, garantia de realização de exame de próstata em funcionários com mais de 40 anos, concessão auxílio-creche até o sexto ano de vida do filho do funcionário, entre outros), maiores proteções sociais para os trabalhadores (garantia estabilidade no emprego durante e após as férias, fixação de jornada diferenciada para trabalhador estudante e trabalhador acidentado, prorrogação da licença-maternidade para mães de filhos prematuros, entre outros) e deixam menor margem de liberdade para negociação (limitação da possibilidade de negociação coletiva tratar sobre ampliação de jornada, fixação de salários, entre outros). Propostas nessa direção foram predominantes entre os partidos da esquerda.

Nesse sentido, é possível dizer que a agenda propositiva da Câmara dos Deputados privilegia a permanência do padrão de relações trabalhistas estruturado a partir da Consolidação das Leis Trabalhistas (CLT) da década de 1940. Apesar de boa parte dos atores envolvidos nas discussões sobre a legislação trabalhista concordarem com a necessidade de modernização desse aparato legal, o fato é que ele amalgamou vários interesses que se criaram e que sobrevivem nesta estrutura antiga e que se recusam a limitar direitos sociais já estabelecidos.

No que concerne à legislação sindical, as propostas apresentadas foram bem mais diminutas que aquelas referentes aos direitos trabalhistas, representando apenas $4 \%$ do total. A maioria delas repetia os preceitos já determinados na Constituição quanto à 
unicidade, contribuições compulsórias, autonomia e liberdade sindicais, reforçando a dificuldade de superação da estrutura sindical conformada também na década de 1940.

\section{2 - Projetos rejeitados e "engavetados": o bloqueio às propostas do Executivo}

A ausência de limites à atividade propositiva dos deputados federais acaba acarretando uma sobrecarga de trabalho nas Casas Legislativas. Para lidar com essa dificuldade, há mecanismos regimentais que buscam agilizar o processo de tramitação e filtrar as propostas que serão objeto de apreciação. Um desses mecanismos é o envio de propostas ao arquivo.

A maioria dos projetos apresentados pelos deputados tiveram como destino o arquivo $(52,4 \%)^{24}$, como é possível verificar na Tabela 1 . Destas, $35,7 \%$ foram arquivadas por força do artigo 105 do Regimento Interno da Câmara. Segundo esse dispositivo, são arquivadas ao término de cada legislatura todas as proposições de autoria dos deputados federais que tenham sido submetidas à deliberação da Câmara e ainda se encontrem em tramitação, pendentes de apreciação de qualquer comissão ou com parecer contrário. Ressalte-se que projetos arquivados podem ser reapresentados por outros parlamentares, recebendo nova numeração e reiniciando a tramitação. Esse tipo de arquivamento ao final da legislatura incide somente sobre os projetos apresentados pelos deputados, restando preservados aqueles apresentados pelo Executivo, mesmo que ao término da legislatura nenhum parecer de alguma comissão sobre eles tenha sido posto a voto.

\footnotetext{
${ }^{24}$ Além das propostas arquivadas ao fim de cada legislatura, também são encaminhadas ao arquivo as propostas que são retiradas de tramitação pelos seus respectivos autores, aquelas que receberam parecer contrário de todas as Comissões responsáveis pela sua análise e as que tenham sido declaradas prejudicadas tendo em vista tratarem de matéria já apreciada pela Casa.
} 


\section{Tabela 1- Situação dos projetos trabalhistas apresentados pelos deputados federais (2003-2014)}

\begin{tabular}{cc}
\hline \multicolumn{1}{c}{ Situação } & Total \\
\hline Arquivado & $\mathbf{7 6 4}$ \\
\hline Final da Legislatura & 273 \\
Rejeitado & 324 \\
Prejudicado (matéria já apreciada) & 39 \\
Aprovação de matéria principal (apensado) & 47 \\
Retirado pelo autor & 42 \\
Devolvido ao autor & 39 \\
\hline Em tramitação & $\mathbf{6 6 9}$ \\
\hline Câmara dos Deputados & 606 \\
Senado Federal & 63 \\
\hline Aprovados & $\mathbf{2 3}$ \\
\hline Convertido em Lei & 22 \\
Vetado totalmente & 3 \\
Vetado parcialmente & 4 \\
\hline Total &
\end{tabular}

Fonte: elaborado pela autora (2016).

É importante ressaltar que 47 proposições que tramitavam apensadas ${ }^{25}$ foram enviadas ao arquivo em razão da aprovação e transformação em lei do projeto principal. Essa situação pode levar a uma subestimação da participação dos parlamentares já que, mesmo que o texto da proposta anexada seja aproveitado na versão de uma lei, ela será considerada arquivada. Há alguns casos em que propostas de autoria de deputados foram anexadas a propostas exitosas do Executivo durante a tramitação, porém, a conclusão da

\footnotetext{
${ }^{25} \mathrm{O}$ instituto da apensação ou da tramitação em conjunto está previsto no Regimento Interno da Câmara dos Deputados nos artigos 142 e 143. Conforme esses dispositivos regimentais, a apensação ocorrerá quando a Mesa da Câmara verificar que já existe em tramitação na Casa proposição da mesma espécie, tratando de matéria idêntica ou correlata. Neste caso, determina-se a apensação (sem incorporação) das proposições, que passam a tramitar em um único processo. No caso de tramitação conjunta, a proposição do Senado tem precedência sobre a da Câmara e a mais antiga sobre a mais recente. Se a Mesa se omitir no momento da distribuição das proposições, os deputados podem requerer que determinada proposição seja apensada a outra.
} 
tramitação resultou em seu envio ao arquivo. Outras 669 proposições de autoria dos deputados federais sobre assunto trabalhistas, apresentados entre 2003 e 2014, ainda permanecem em tramitação, seja na própria Câmara dos Deputados, seja no Senado Federal (63 proposições). Destas, 454 tramitam apensadas. O instituto do apensamento é outro recurso regimental que busca tornar o processo legislativo mais eficiente e ágil, por meio do agrupamento de projetos que versem sobre mesma temática.

Com relação aos projetos de autoria dos deputados federais convertidos em lei, esses totalizaram 22. Os projetos transformados em norma jurídica serão analisados com mais detalhes na próxima seção.

Com relação às propostas originárias do Executivo, cinco foram arquivadas $(15,15 \%)$, uma foi retirada de tramitação por ação do próprio Executivo, seis permanecem em tramitação e 21 foram convertidas em lei. A situação dos projetos do Executivo pode ser observada na Tabela 2.

Tabela 2 - Situação dos projetos trabalhistas apresentados pelo Poder Executivo (2003-2014)

\begin{tabular}{l|c}
\hline \multicolumn{1}{c|}{ Situação } & Total \\
\hline Arquivado & $\mathbf{5}$ \\
Rejeitado & 1 \\
Prejudicado (matéria já apreciada) & 1 \\
Aprovação de matéria principal (apensado) & 2 \\
Retirado pelo autor & 1 \\
\hline Em tramitação & $\mathbf{6}$ \\
\hline Câmara dos Deputados & 6 \\
Tramitando apensado & 4 \\
\hline Convertidos em lei & $\mathbf{2 2}$ \\
\hline Veto parcial & 4 \\
\hline Total & $\mathbf{3 3}$ \\
\hline
\end{tabular}

Fonte: elaborado pela autora (2016).

A existência de projetos retirados pode ser interpretada como exemplo das dificuldades enfrentadas pelo Executivo para aprovação de sua agenda. O caso do PL $\mathrm{n}^{\circ}$ 
2.204/2007, que dispunha sobre o Programa de Nacional de Inclusão de Jovens Projovem, é ilustrativo. O Presidente, prevendo possíveis resistências à tramitação da proposta na qualidade de projeto de lei ordinária e um tempo relativo maior para sua aprovação, solicitou sua retirada e apresentou uma Medida Provisória para tratar do tema.

Visto que a rejeição explícita de projetos do Executivo é fenômeno bastante raro, a existência de projetos rejeitados exemplifica uma atuação do Legislativo voltada para derrotar as propostas do Executivo contrários ao seu interesse. O único projeto do Executivo rejeitado no período foi a MP 293/06, que integrava a proposta do governo do Presidente Lula para a reforma sindical e reconhecia as centrais sindicais como representantes das organizações sindicais a elas filiadas para participar de negociações em fóruns, colegiados de órgãos públicos e espaços de diálogo social que possuam composição tripartite. Antes da edição da MP, a representação dos trabalhadores se limitava aos sindicatos (cuja área de atuação é de, no mínimo, um município); às federações (que são coligações regionais de sindicatos); e às confederações (entidades sindicais nacionais. Quando da edição da MP haviam 17 centrais sindicais existentes, que vinham atuando na informalidade.

A Medida era bastante polêmica e foi rejeitada porque os deputados consideraram que o assunto, na época, dividia o movimento sindical, e necessitava de um debate mais aprofundado. O movimento de resistência à proposta era liderado especialmente por federações e confederações de trabalhadores que, inclusive entraram com Ação Direta de Inconstitucionalidade (ADI) no Supremo Tribunal Federal contra a MP, que segundo elas quebrava o princípio da representatividade por categoria profissional e instituía a representatividade por associação. A proposta foi rejeitada na forma do parecer do relator da Comissão Mista, deputado Medeiros (PL/SP), cujo partido pertencia à base aliada do governo.

Projetos que permanecem em tramitação por longo período também podem representar uma atuação dos deputados direcionada ao bloqueio de projetos do Executivo. A não-decisão, muitas vezes, pode ser menos custosa do que colocar o projeto em votação e rejeitá-lo. Conforme Diniz (2005), “engavetar" um projeto durante o curso de sua tramitação seria um recurso estratégico do Legislativo, mais vantajoso que levar o projeto a voto e rejeitá-lo. É consensual na literatura, no entanto, que o Executivo detém importantes poderes legislativos que lhe permite acelerar o trâmite de suas propostas (uso de MPs, pedidos de urgência, etc.). Nesse cenário, a existência de uma proposição de 
autoria Executivo em tramitação por tempo indeterminado significa que tais poderes de agenda não foram utilizados. E qual seria a razão para o Executivo não fazer uso deles? Uma possibilidade diz respeito ao desinteresse desse Poder em relação à matéria. Ou seja, por meio da apresentação da proposta o Executivo sinaliza à opinião pública que tomou a iniciativa de propor e de colocar o tema em debate e a imagem de inativo ou resistente fica com o Legislativo.

Exemplifica a situação a tramitação até hoje não concluída do PL $\mathrm{n}^{\circ}$ 4.731/2004, que compôs o pacote de projetos enviados pelo Presidente Lula ao Congresso Nacional para promover a reforma processual do trabalho. O projeto estabelece, para o executado em processo trabalhista, as alternativas de pagar o valor devido em até 48 horas ou de penhorar os bens que possui, ainda que sejam insuficientes para o pagamento integral do valor. O projeto foi aprovado nas duas comissões de mérito responsáveis por sua análise (CTASP e CCJC), conforme pareceres emitidos pelo deputado Vicentinho do PT de São Paulo e pelo deputado Mendes Ribeiro do PMDB do Rio Grande do Sul, respectivamente. Segundo despacho proferido pela Secretaria Geral da Mesa, o projeto tramitava conclusivamente pelas Comissões. No entanto, durante o prazo regimental previsto para apresentação de recurso contra essa apreciação conclusiva das Comissões, o deputado Flávio Dino do PCdoB valeu-se de tal disposição, a fim de postergar a tramitação da matéria, e solicitou seu envio também à análise do Plenário. O projeto encontra-se, desde então (2007), aguardando apreciação do recurso. O Executivo não solicitou urgência para tramitação da proposta e também não atuou para colocar o recurso em votação, demonstrando certo desinteresse em relação à aprovação da proposição.

Mesmo diante dessas dificuldades, não é possível afirmar que o Legislativo funcionou como entrave intransponível aos projetos do Executivo, já que a maioria dos projetos trabalhistas que compunham a agenda deste Poder foram transformados em norma $(63,3 \%)$. Como se verá na próxima seção, a maior parte de projetos do Executivo foi aprovada com alterações, o que demonstra um processo de negociações com vistas a conformar, em alguma medida, o conteúdo das propostas aos interesses dos parlamentares. 


\section{3 - Projetos convertidos em lei e vetados: interferência do Legislativo e a negociação com o Executivo}

A discussão das iniciativas em matéria trabalhista não pode prescindir da análise das propostas que, afinal, transformaram-se em normas jurídicas. Apresenta-se assim um breve panorama do conjunto da legislação trabalhista aprovada no período de 2003 a 2014.

Há uma ligeira preponderância entre as leis aprovadas de propostas com origem parlamentar. Foram 43 projetos convertidos em norma jurídica no período analisado. Destes, 21 projetos foram iniciados pelo Executivo, enquanto 22 tiveram como fonte os deputados federais. Apesar de aprovarem um número proporcionalmente menor de projetos (total apresentado/total convertido em lei), o fato é que os parlamentares foram autores da maioria das leis que afetaram as relações de trabalho no país durante o período analisado.

Coopera com esse volume de projetos de autoria de deputados federais aprovados a existência do instituto do "poder conclusivo" ou "terminativo" das Comissões Permanentes. Por meio deste instrumento as Comissões podem aprovar uma proposta diretamente, sem que seja necessário submetê-la à deliberação do Plenário, salvo se aprovado recurso próprio. Para se ter uma ideia, quase $68,2 \%$ (15 projetos) das proposições legislativas trabalhistas de autoria dos deputados sancionadas no período foram aprovadas em caráter conclusivo. Ou seja, passaram apenas pelas comissões temáticas, sem ir a Plenário. Os outros $31,8 \%$ ( 7 projetos) passaram pelo escrutínio do Plenário com requerimento de urgência (previsto nos artigos 154 e 155 do Regimento Interno da Câmara). Tal requerimento deve ser subscrito pela maioria absoluta da composição da Câmara, ou por lideranças partidárias que representem esse número, e aprovado pela maioria absoluta dos deputados. A aprovação da urgência permite a discussão e a votação imediata de proposição, acelerando sua tramitação e ampliando suas chances de se tornar lei. Para fins de comparação, entre as propostas do Executivo convertidas em lei, 71,5\% tramitou em urgência.

Se excluirmos da análise os projetos que estabelecem homenagens e datas comemorativas, visto desempenharem papel simbólico e não instituírem direitos e obrigações, os deputados federais aparecem como autores de 18 de leis, contra 21 do Poder Executivo. Isso poderia corroborar com aquelas vertentes da literatura que apontam 
que a legislação originária dos parlamentares versa, em geral, sobre questões secundárias ou acessórias, enquanto os temas mais fundamentais são regulamentados em iniciativas do Poder Executivo.

O entendimento do que sejam temas substantivos e temas secundários é controverso, no entanto, algumas questões, pela sua própria natureza, repercussão ou impacto, destacam-se como de razoável e evidente magnitude. Assim, observa-se que, das 22 leis publicadas no período com origem parlamentar, pelo menos cinco voltaramse a questões de grande relevância: (1) aquela que institui o adicional de periculosidade para os vigilantes e empregados de transporte de valores; (2) outra que criou o valecultura do trabalhador; (3) a que estabeleceu a igualdade de direitos trabalhistas entre os empregados domésticos e os demais trabalhadores urbanos e rurais; (4) outra que alterou em profundidade o processamento de recursos na Justiça do Trabalho; e (5) aquela que regulamentou o teletrabalho ou trabalho realizado à distância. Esses assuntos citados dificilmente podem ser classificados como de menor relevância ou de introdução de mudanças pouco significativas.

É digno de nota ainda que a única Proposta de Emenda à Constituição aprovada no período era de autoria de um deputado. Mesmo diante da dificuldade de promover alterações legislativas pela via constitucional (uma PEC demanda mobilização de maiorias, visto serem necessários dois terços dos votos em ambas as Casas Legislativas para ser aprovada), o Legislativo operou alteração na constituição a fim de assegurar tratamento igualitário para os empregados domésticos.

Com relação à capacidade de aprovar, cada um dos 22 projetos trabalhistas convertidos em lei teve como autor um deputado diferente. Ou seja, nenhum deputado conseguiu, no período analisado, converter em norma mais de um projeto de sua autoria. Com relação aos partidos por trás dos projetos transformados em lei, identificamos uma prevalência, mais uma vez, dos partidos de esquerda. O PT converteu em lei 6 projetos, seguido pelo PDT (3), PCdoB (3) e PSB (2). Foram 14 projetos da esquerda, contra um do centro e oito da direita.

Observa-se que as iniciativas dos deputados federais transformadas em norma jurídica tenderam a se concentrar nos seguintes temas: regulamentação de profissões (taxista, direito morais dos dubladores, disposições sobre o exercício da profissão de motorista, etc.); homenagens e datas comemorativas; e processos judiciais trabalhistas. Do lado do Poder Executivo, as iniciativas convertidas em lei contemplam 
preponderantemente: inclusão no mercado de trabalho (jovens, sobretudo) e processos judiciais trabalhistas. O Quadro 9 apresenta a distribuição temática dos projetos transformados em norma jurídica, por autoria.

\section{Quadro 9 - Distribuição temática dos projetos transformados em norma jurídica, por autoria (2003-2014)}

\begin{tabular}{|l|c|c|}
\hline \multicolumn{1}{|c|}{ Área temática } & Legislativo & Executivo \\
\hline Benefícios sociais & 1 & 1 \\
\hline Homenagens e datas comemorativas & 4 & 1 \\
\hline Modalidade de contratos & 1 & 2 \\
\hline Inclusão no mercado de trabalho & - & 3 \\
\hline Política salarial & 3 & 2 \\
\hline Processos judiciais trabalhistas & 1 & - \\
\hline Demissão e rescisão de contrato/estabilidade & 5 & - \\
\hline Regulamentação de profissões & 1 & - \\
\hline Segurança e saúde no trabalho & - & 1 \\
\hline Direitos humanos/trabalho escravo ou degradante & - & 1 \\
\hline Apoio ao desempregado/seguro-desemprego & 1 & 2 \\
\hline Situações de afastamento/licenças & 1 & - \\
\hline Discriminação no mercado de trabalho & 1 & 1 \\
\hline Duração do trabalho & 2 & 1 \\
\hline Organização sindical e contribuição & - & 1 \\
\hline Qualificação do trabalhador & $\mathbf{2 2}$ & 1 \\
\hline Tributação & $\mathbf{2 1}$ \\
\hline Outros* & & 1 \\
\hline Total & - & - \\
\hline
\end{tabular}

Fonte: elaborado pela autora (2016)

* Na categoria “outros” estão inclusos os seguintes temas: administração pública (proposta do Executivo); e cooperativas de trabalho (proposta do Legislativo).

O tema processos judiciais trabalhistas aparece com relevância tanto entre os deputados quanto no Executivo, seja no rol de projetos apresentados quanto no de aprovados, devido à importância desempenhada pelos órgãos da Justiça do Trabalho no Brasil para definição das relações trabalhistas no país. Esses órgãos lidam com cerca de 
quatro milhões de processos por ano ${ }^{26}$ e seus julgados acabam gerando normas, tendo em vista a força dos enunciados, orientações jurisprudenciais e precedentes criados. No geral, as propostas sobre o tema no Congresso, objetivam diminuir o número de processos na Justiça do Trabalho, bem como o tempo de tramitação dos processos, com redução dos recursos e prazos.

Quanto ao tempo decorrido antes de se converterem em lei, os projetos dos deputados levaram, em média, 4 anos e 11 meses tramitando. Apenas duas, das 22 propostas do legislativo, levaram menos de um ano para se tornarem lei. Por seu turno, as propostas do Executivo tramitaram por um período quase 4 vezes menor -1 ano e 4 meses. Apenas 7, das 21 proposições desse Poder, tramitaram por mais de um ano no Congresso. Houve, inclusive, um projeto do Executivo que levou apenas 6 dias de tramitação até virar norma (PL n ${ }^{\circ} 382 / 2011$, que instituiu a política de valorização do salário mínimo, convertido na Lei $\left.\mathrm{n}^{\mathrm{o}} 12.382 / 2011\right)$. Ocorre que boa parte das matérias do Executivo postas em votação eram Medidas Provisórias, que possuem constitucionalmente um tempo máximo para serem apreciadas (120 dias), o que puxou a média para baixo. Além disso, outra relevante fração dos projetos do Executivo tramitou em regime de urgência.

Tendo em vista a capacidade institucional que detém os parlamentares de introduzir modificações nos projetos do Executivo, passa-se, agora, à análise das regularidades encontradas no processo de alteração dos projetos, bem como ao exame dos projetos que não sofreram alterações. $\mathrm{Na}$ Tabela 3 abaixo destaca-se a origem da iniciativa, o tipo de proposição original e a existência de intervenção ou não dos deputados federais nos textos aprovados, em termos de emendamento parcial ou global. Essa análise é essencial para determinar o grau de participação do Legislativo no processo decisório. Os dados estão divididos de acordo com o período presidencial a que se referem (Luiz Inácio Lula da Silva I: 2003-2006; Luiz Inácio Lula da Silva II: 2007-2010; e Dilma Rousseff: 2011-2014).

\footnotetext{
${ }^{26}$ Conforme levantamento realizado anualmente pelo Conselho Nacional de Justiça (CNJ) e divulgado no boletim "Justiça em Números", em 2014 a Justiça do Trabalho recebeu quatro milhões de novos processos, mesmo número registrado em 2013.
} 
Tabela 3- Leis trabalhistas publicadas, por tipo de proposição originária, segundo o Poder de origem e o grau de alteração do texto original pelos deputados federais (2003-2014)

\begin{tabular}{c|c|c|c|c|c|c|c|c|}
\hline $\begin{array}{c}\text { Período/ Tipo de } \\
\text { proposição } \\
\text { originária }\end{array}$ & \multicolumn{4}{c|}{ Executivo } & \multicolumn{5}{c}{ Legislativo } \\
\hline & Total & $\mathrm{OR}^{*}$ & $\mathrm{EM}^{*}$ & $\mathrm{SUB} *$ & Total & $\mathrm{OR}^{*}$ & $\mathrm{EM}^{*}$ & $\mathrm{SUB}^{*}$ \\
\hline
\end{tabular}

Lula I (2003 -2006)

\begin{tabular}{l|c|c|c|c|c|c|c|c}
\hline Medida Provisória & 4 & 1 & 0 & 3 & 0 & 0 & 0 & 0 \\
\hline PEC & 0 & 0 & 0 & 0 & 0 & 0 & 0 & 0 \\
\hline Projeto de lei & 7 & 4 & 2 & 1 & 11 & 4 & 2 & 5 \\
\hline Total & 11 & 5 & 2 & 4 & 11 & 4 & 2 & 5 \\
\hline
\end{tabular}

Lula II (2007-2010)

\begin{tabular}{l|l|l|l|l|l|l|l|l}
\hline Medida Provisória & 2 & 1 & 0 & 1 & 0 & 0 & 0 & 0 \\
\hline Emenda à CF & 0 & 0 & 0 & 0 & 1 & 0 & 0 & 1 \\
\hline Projeto de lei & 3 & 1 & 2 & 0 & 6 & 2 & 3 & 1 \\
\hline Total & 5 & 2 & 2 & 1 & 7 & 2 & 3 & 2 \\
\hline
\end{tabular}

Dilma (2011-2014)

\begin{tabular}{l|l|l|l|l|l|l|l|l}
\hline Medida Provisória & 3 & 0 & 0 & 3 & 0 & 0 & 0 & 0 \\
\hline PEC & 0 & 0 & 0 & 0 & 0 & 0 & 0 & 0 \\
\hline Projeto de lei & 2 & 0 & 1 & 1 & 3 & 0 & 1 & 2 \\
\hline Total & 5 & 0 & 1 & 4 & 3 & 0 & 1 & 2 \\
\hline
\end{tabular}

Fonte: Elaborado pela autora (2014).

*OR: texto original aprovado sem alterações; EM: texto aprovado com emendas; SUB: texto aprovado na forma de substitutivo, considerado como tal, no caso de medida provisória, o projeto de lei de conversão que altera significativamente o seu conteúdo.

O processo de emendamento é facultado a todos os parlamentares. Em outras palavras, qualquer congressista insatisfeito com a proposta enviada pelo Executivo pode sugerir alterações à mesma em quantidade ilimitada. Sugerir, mas não necessariamente aprovar. Aprovar é um passo seguinte, que demanda coordenação e formação de maiorias.

As emendas são proposições destinadas a alterar a forma ou o conteúdo das proposições principais. Podem suprimir, modificar, acrescentar, substituir ou aglutinar partes do texto a ser alterado. Há um tipo de emenda, o substitutivo, que merece menção especial. O substitutivo destina-se a alterar substancialmente o texto da proposição principal. Apesar de formalmente enquadrado no Regimento Interno como espécie de emenda, o substitutivo pode assumir característica de proposição principal durante o processo de apreciação da matéria. Isso porque, se for aprovado pela instância 
responsável por sua análise - e essa é uma hipótese muito comum - passará a ter preferência, na discussão e na votação, sobre o texto original da proposição. Substitutivos apenas podem ser apresentados pelos relatores (de Comissões ou de Plenário), enquanto as emendas podem ser sugeridas por qualquer deputado federal.

Há, basicamente, dois momentos para apresentação de emendas dentro da Câmara dos Deputados: um no âmbito das Comissões e outro no Plenário. Se uma proposição for despachada pela Mesa apenas ao exame das Comissões, sem necessidade do Plenário (poder conclusivo das Comissões), as emendas poderão ser apresentadas em cada colegiado responsável por sua análise. Qualquer deputado, inclusive não membros, poderá propor emendas que serão avaliadas pelo relator e pela Comissão. Se, no entanto, o projeto incluir também a competência do Plenário, prazo para apresentação de emendas será aberto nessa instância de apreciação, durante o período de discussão da matéria.

As proposições urgentes ou que venham a se tornar urgentes (por força de requerimento subscrito pela maioria absoluta da composição da Câmara, ou por lideranças partidárias que representem esse número, e aprovado pela maioria absoluta dos deputados) dispensarão a fase de Comissões e as emendas serão propostas no Plenário, seguindo-se imediatamente para sua avaliação e deliberação. Importante frisar que 46,5\% dos projetos trabalhistas aprovados na Câmara dos Deputados e transformados em norma jurídica no período tramitaram em regime de urgência, sendo 6 propostas de origem dos deputados e 14 do Executivo.

No geral, observa-se que as leis do Poder Executivo aprovadas sofreram, durante a tramitação de seus projetos, intervenção significativa dos deputados federais. Do total dos 21 projetos desse Poder, 5 (23,8\%) foram aprovadas com emendas, 9 (42,8\%) na forma de um substitutivo ou de um projeto de lei de conversão e 7 (33,3 \%) tiveram seus textos originais mantidos. Entre as propostas do Legislativo, também é frequente a alteração do texto original seja por meio de emendas seja por meio de substitutivo. Importante destacar que também o governo, por meio dos parlamentares de sua base aliada, introduz mudanças nas redações das propostas dos deputados. Contudo, a análise dessas modificações não é objeto desta pesquisa.

No período presidencial de Luiz Inácio Lula da Silva I, das 4 MPs editadas, apenas uma passou com texto incólume, enquanto as demais foram alvo de projetos de lei de conversão, que alteraram sobremaneira seu conteúdo. No período de Dilma Rousseff, duas das três Medidas Provisórias foram objeto de projetos de lei de conversão 
e uma recebeu emendas relevantes. Os governos do Presidente Lula foram mais bemsucedidos quanto à manutenção do texto original de suas propostas, quando comparados com o governo da Presidente Dilma.

No total, sete $(33,3 \%)$ propostas do governo passaram sem alteração pelo Congresso. O fato de não haver alterações nestas matérias não exclui, contudo, a possibilidade de que tenha havido uma negociação prévia entre as lideranças do Executivo e os partidos aliados no Congresso a fim de construir acordos prévios para colocar estas matérias em votação. Nesse sentido, a maior taxa de aprovação do texto original de projetos de autoria do Executivo não seria um indicador consistente de imposição unilateral de uma agenda, mas de produção de consensos e cooperação pelo sistema político.

Foram apresentadas pelos deputados federais um total de 666 emendas a iniciativas do Executivo. Dessas, 206 (31\%) foram aprovadas no todo ou em parte e se fizeram refletir no texto final da proposta. A análise apenas das emendas, no entanto, não é suficiente para captar o nível de interferência do Legislativo nas propostas do Poder Executivo, tendo em vista que importantes modificações são introduzidas pelos relatores das matérias (seja no âmbito das comissões, seja no do Plenário), por meio de substitutivos ou projetos de lei de conversão. Nesse sentido, faz-se relevante examinar o número de dispositivos do governo sob os quais houve alguma ação dos parlamentares. Consideram-se aqui apenas as interferências que tenham sido aprovadas e, portanto, incorporadas ao conteúdo final.

Se forem contabilizados cada um dos dispositivos que foram alvo de ação do Legislativo (supressão, modificação e adição), ter-se-á um total de 223. Isso não quer dizer que os deputados foram os autores de 223 dispositivos nos textos de redação final aprovados. Quer dizer que eles exerceram atividade em 223 dispositivos. Tomemos como exemplo, uma Medida Provisória Y, que possui 15 dispositivos. O relator da Comissão Mista responsável por sua análise acatou 7 emendas, cada uma adiciona 2 dispositivos à proposta. Ademais, em seu relatório, ele propôs modificações em 11 dispositivos do texto original, consolidando todas essas ações em um projeto de lei de conversão (PLV). As intervenções do Legislativo somam, portanto, 25 dispositivos. Com a aprovação do PLV pelo Plenário, a redação final aprovada teria 29 dispositivos.

Se apenas analisássemos o total de dispositivos no texto final vis-à-vis os dispositivos do texto original, não teríamos uma métrica adequada da participação do 
Legislativo, pois estariam omitidas do resultado as modificações efetuadas. Por isso, é importante somar todos os dispositivos com ação do Legislativo. Uma consideração de ordem analítica precisa ser feita aqui: a análise se restringe a existência ou não de ações do Legislativo em termos de emendas e substitutivos nas matérias sancionadas, ou seja, não se está analisando o conteúdo dessas emendas e substitutivos ou seu impacto "qualitativo".

Quanto à quantidade de dispositivos do Executivo, que constavam nos projetos que foram enviados à Câmara dos Deputados, contabilizados antes de qualquer ação do Legislativo, esses totalizaram 526. Já os dispositivos que constaram das leis publicadas, estes totalizaram 643 (essa contabilização inclui os eventuais vetos parciais aplicados). Esses detalhamentos podem ser melhor observados na Tabela 4.

\section{Tabela 4- Número de projetos e dispositivos por categoria}

\begin{tabular}{c|c|c|c|c|c|c}
\hline $\begin{array}{c}\text { Tipo de } \\
\text { projeto }\end{array}$ & $\begin{array}{c}\mathbf{N}^{\mathbf{0}} \text { de } \\
\text { projetos }\end{array}$ & $\begin{array}{c}\text { Dispositivos } \\
\text { do } \\
\text { Executivo }\end{array}$ & $\begin{array}{c}\text { Dispositivos } \\
\text { com ação dos } \\
\text { parlamentares }\end{array}$ & $\begin{array}{c}\text { Dispositivos } \\
\text { da Lei* }\end{array}$ & $\begin{array}{c}\text { Dispositivos } \\
\text { do Executivo } \\
\text { na Lei }\end{array}$ & $\begin{array}{c}\text { Dispositivos } \\
\text { do Legislativo } \\
\text { na Lei }\end{array}$ \\
\hline MP & 9 & 244 & 145 & 322 & $195(60,5 \%)$ & $127(39,5 \%)$ \\
PL & 12 & 282 & 78 & 321 & $246(76,6 \%)$ & $75(23,4 \%)$ \\
\hline Total & $\mathbf{2 1}$ & $\mathbf{5 2 6}$ & $\mathbf{2 2 3}$ & $\mathbf{6 4 3}$ & $\mathbf{4 4 1 ( 6 8 , 5 \% )}$ & $\mathbf{2 0 2 ( 3 1 , 5 \% )}$ \\
\hline
\end{tabular}

Fonte: elaborado pela autora (adaptação FREITAS, 2014).

* Dispositivos na Lei contabilizados após o recebimento de eventuais vetos.

Dos dispositivos com atuação dos deputados federais, 58 tiveram o condão de modificar a redação (modificativos), 155 de adicionar dispositivo novo (aditivos) e 10 de suprimir (supressivos). A maior parte das intervenções foram feitas nos textos das Medidas Provisórias, especialmente na MP nº 665/2014 (mudou as regras de concessão do seguro-desemprego, do abono salarial e do seguro-defeso para o pescador profissional artesanal e fez parte do pacote de ajuste fiscal do governo da Presidente Dilma), na MP n $411 / 2007$ (reformulou o Projovem, dividindo o Programa em quatro modalidades: adolescente, urbano, campo e trabalhador) e na MP n ${ }^{\circ}$ 597/2012 (disciplinou a tributação exclusiva na fonte do Imposto de Renda para as parcelas de participação nos lucros recebidas pelos trabalhadores).

Conforme se observa, o número de alterações feitas no interior do Legislativo, independentemente do tipo de proposta, não é pequeno, demonstrando o volume da participação dos deputados federais na definição das políticas. No entanto, ainda é preciso 
compreender qual a contribuição real dos deputados para os textos aprovados. Para tanto, é preciso verificar quantos dos dispositivos que estão presentes no texto da Lei tiveram origem no Poder Executivo e quantos foram inseridos no Poder Legislativo. A contribuição dos parlamentares pode ser medida da seguinte maneira ${ }^{27}$ :

$$
\mathrm{C}_{\mathrm{L}}=\mathrm{D}_{\mathrm{LL}} / \mathrm{D}_{\mathrm{NJ}} * 100, \text { sendo }
$$

$\mathrm{C}_{\mathrm{L}}=$ Contribuição do Legislativo

$\mathrm{D}_{\mathrm{LL}}=$ Dispositivos do Legislativo na Lei

$\mathrm{D}_{\mathrm{NJ}}=$ Dispositivos na norma jurídica

Já a contribuição média (percentual) do Executivo pode extraída da seguinte forma:

$$
\mathrm{C}_{\mathrm{E}}=\mathrm{D}_{\mathrm{EL}} / \mathrm{D}_{\mathrm{NJ}} * 100, \text { sendo }
$$

$\mathrm{C}_{\mathrm{E}}=$ Contribuição do Executivo

$\mathrm{D}_{\mathrm{E}}=$ Dispositivos do Executivo na Lei

$\mathrm{D}_{\mathrm{NJ}}=$ Dispositivos na norma jurídica

Nesse sentido, tem-se que a contribuição do Executivo no conjunto das leis trabalhistas de sua autoria, no período analisado, foi de 68,5\%, enquanto a do Legislativo foi de 31,5\% (vide Tabela 4). Obviamente, o Executivo é a principal fonte dos dispositivos legais oriundos das propostas de sua autoria. No entanto, a contribuição do Legislativo revela que esse Poder não é apático na produção de políticas. No que concerne às Medidas Provisórias, especificamente, a contribuição do Legislativo para o texto da norma foi de cerca de $40 \%$. Nesse sentido, é preciso relativizar o entendimento das Medidas Provisórias como instrumento que permite ao Executivo legislar em detrimento do Legislativo e impor sua agenda, já que elas foram, pelo menos na área trabalhista, objeto de significativa interferência dos deputados. Mesmo o rito de tramitação acelerado de MPs não impediu a consideração e alteração destas pelos

\footnotetext{
${ }^{27}$ Freitas (2014) desenvolveu o que ela denomina taxa de contribuição. A proposta desta dissertação baseiase na medida estabelecidas pela autora, porém, com algumas adaptações.
} 
parlamentares. Nesse ponto é importante ressaltar o papel das assessorias legislativas e dos grupos ou setores organizados, que fornecem aos parlamentares material técnico capaz de instruir as alterações e fundamentá-las. São esses grupos que possuem capacidade técnica e pessoal suficiente para avaliar as propostas iniciadas pelo Executivo em tempo hábil.

Aqui, cabe uma pergunta: teriam os partidos governistas dominado este cenário das alterações nos projetos ou a oposição conseguiu interferir nas políticas enviadas pelo Executivo? O sucesso na aprovação de emendas aumenta na medida em que o partido de seu proponente pertença à coalizão de governo? É relevante examinar a questão partidária por trás das emendas, tendo em vista o peso que os partidos políticos têm no âmbito do Poder Legislativo brasileiro, inclusive nas regras de sua organização.

Nesse quesito, o PT figurou como principal autor (controlou cerca de $30 \%$ das alterações), seguido nessa ordem, por PSDB (14\%), DEM/PFL (12\%), PPS (7,5\%), PDT (7\%), PCdoB (7\%), PTB (5,5\%) e PSC (5\%). Outros partidos também modificaram o texto, suas alterações correspondem, somadas, a $12 \%$ do total de interferências efetuadas pelo Legislativo nas propostas do Executivo convertidas em lei. Importante notar que a predominância no PT pode estar relacionada a dois fatores: tamanho de sua bancada, comparativamente aos demais partidos durante as legislaturas analisadas; e ao fato de que a maioria das alterações do partido foram efetuadas por parlamentares da sigla que ocupavam a posição de relator da matéria, evidenciando maior controle do partido sobre as matérias do governo em andamento.

Mesmo diante do predomínio do PT, é possível dizer que a oposição (PSDB, PFL/DEM e PPS) conseguiu, no campo das políticas trabalhistas, interferir no processo decisório deixando sua marca no conteúdo das propostas. Apesar das relatorias estarem com parlamentares da base e o resultado da aprovação de emendas passar pelos relatores, a oposição conseguiu, em boa medida, se fazer ouvir, pois os pareceres acabaram sendo favoráveis a várias interferências dos deputados de partidos de oposição. Isso indica que, muitas vezes, a aprovação das matérias do governo esteve condicionada à promoção de negociações e acordos com a oposição a fim de "aparar arestas" do texto e viabilizar apoio e a aprovação de determinadas matérias, inclusive das mais complexas, que recebem inúmeras emendas.

Esses dados permitem assegurar, que a possibilidade de emendamento ou apresentação de substitutivo/projeto de lei de conversão foram um importante recurso 
com o qual contou tanto o governo, a partir da atuação de sua base aliada, quanto a oposição. Esta com o intuito de aproximar as propostas trabalhistas do governo aos seus interesses e aquele com o intuito de viabilizar negociações e garantir a aprovação de suas propostas. É preciso considerar que nem todas as mudanças feitas em matérias oriundas do Executivo são necessariamente contrárias ao interesse desse Poder, pois, por vezes, o próprio Executivo pode concordar com mudanças que venham reforçar ou aprimorar seus objetivos. O que precisa ser apontado é que o fato de haver uma mudança no projeto inicialmente concebido indica que houve uma negociação política entre o governo, sua base na Câmara e a oposição para se alcançar um consenso que permitisse aprovar o projeto.

Do total de projetos trabalhistas aprovados, 9 foram alvo de vetos parciais; 4 em projetos de autoria do Executivo e 5 em projetos dos deputados. Houve, ainda, dois vetos totais a projetos dos parlamentares. Há pontos que podem ser inegociáveis para ambos os lados e os vetos totais podem indicar isso, mas estes não são numericamente predominantes. Os projetos vetados não passaram pelo Plenário, eles foram apreciados conclusivamente pelas comissões, o que sugere que o monitoramento pela base aliada não foi tão eficiente nessas instâncias, a fimm de evitar aprovação de matérias contrárias à agenda do governo.

Os vetos apostos às propostas do Executivo, foram direcionados majoritariamente a dispositivos introduzidos pelos congressistas (16 dispositivos inseridos ou modificados pelos parlamentares durante a tramitação dos projetos foram alvo de vetos). A maior parte das matérias alteradas pelo Legislativo, porém, não sofreu vetos presidenciais. Os vetos foram direcionados, majoritariamente, à MP n ${ }^{0}$ 665/2014 (transformada na Lei $\left.\mathrm{n}^{\circ} 1.3134 / 2015\right)$, que mudou as regras de concessão do segurodesemprego, do abono salarial e do seguro-defeso para o pescador profissional artesanal e fez parte do pacote de ajuste fiscal do governo da Presidente Dilma. Essa proposta recebeu um projeto de lei de conversão que introduzia várias modificações nos dispositivos originais. Os vetos, nesse caso, revelam o grau de conflito da matéria e indicam que o Executivo não conseguiu influenciar sua tramitação como desejado. Os vetos à proposta foram apreciados em sessão conjunta e mantidos pelo Congresso.

$\mathrm{Na}$ verdade, nenhum dos vetos a projetos trabalhistas apreciados no período foi derrubado, o que poderia sugerir que eles não contrariaram os interesses do Legislativo. Entretanto, as deliberações dos vetos ocorreram alguns anos após a sua 
imposição, várias delas em outra legislatura, o que provoca modificação no contexto de preferência dos atores (GOMES, 2011).

Também houve caso de veto à dispositivo que constava do projeto original do governo e que não foi alterado no interior do Legislativo. Isso pode refletir em alguma medida o fato de que o Executivo não é uma instância homogênea em termos de preferências, como somos levados a imaginar. Dentro desse Poder existem interesses conflitantes que alteram seu rol de preferências no tempo. Isso é especialmente verdade em contextos de presidencialismo de coalizão, onde a construção de apoio pelo Presidente no Legislativo impõe a construção de uma base aliada muito diversa do ponto de vista político e ideológico. Em alguns casos, inclusive, a coordenação das preferências políticas entre os membros da coalizão é tão difícil que as tensões provenientes desta relação acabam por ser resolvidas no processo de tramitação das proposições, ou seja, no interior do Legislativo.

\section{4 - Conclusão}

A pesquisa conduzida até aqui permitiu confirmar a primeira hipótese descritiva central desta pesquisa, segundo a qual, apesar das prerrogativas legislativas que dispõe o Presidente para fazer valer sua agenda, os parlamentares desempenham papel ativo no processo de conformação das políticas trabalhistas e sindicais.

Os deputados federais propuseram mais projetos nesta seara do que o Executivo. Os dados levantados mostraram que as políticas públicas trabalhistas/sindicais constituem área de significativo interesse legislativo para os deputados. A proporção de proposições sobre o tema no conjunto de iniciativas parlamentares no período considerado assinala o apelo social e políticos das questões trabalhistas.

Os parlamentares converteram em lei, proporcionalmente, menos projetos do que o Executivo. No entanto, em números absolutos, eles foram mais bem-sucedidos em transformar suas propostas em norma jurídica. Inclusive, a única PEC convertida em lei no período originou-se de uma proposta parlamentar e não do governo. A maior parte dos projetos dos deputados aprovados trataram sobre a regulamentação de profissões $(22,7 \%)$ ou estabeleceram homenagens e datas comemorativas (18,2\%). Essa preferência pode reforçar a visão de que a legislação originária dos parlamentares versa, em geral, sobre questões marginais, enquanto os temas mais fundamentais são tratados pelo Poder 
Executivo. Não obstante, questões relevantes também foram alvo de projetos dos deputados convertidos em lei. São elas, por exemplo: o estabelecimento do adicional de periculosidade para os vigilantes e empregados de transporte de valores; a criação o valecultura do trabalhador; a igualdade de direitos trabalhistas entre os empregados domésticos e os demais trabalhadores urbanos e rurais; entre outros.

Importante frisar que nenhum dos dois Poderes conseguiu garantir aprovação de projetos que reformasse, de maneira significativa as relações individuais de trabalho (promovendo a flexibilização de direitos) e as relações coletivas (extinguindo a unicidade sindical e a contribuição compulsória, por exemplo), apesar de terem sido apresentados projetos com esse propósito.

Os deputados rejeitaram apenas um projeto trabalhista/sindical do Executivo no período. Apesar desse ponto de tensão, é possível assegurar que a relação entre os dois Poderes nesse campo de política é marcada mais por cooperação do que por conflito entre as agendas, havendo concessões do primeiro e significativa intervenção do segundo, sem prejuízo da "governabilidade".

Além das leis de sua autoria, os deputados também foram responsáveis por diversos dispositivos $(31,5 \%)$ constantes das propostas do Executivo transformadas em lei. Essas intervenções foram possíveis em razão da possibilidade regimental de apresentação de emendas. A consagração dessas emendas parlamentares na redação final das leis oriundas do Executivo indicam que houve um processo de negociação com esse Poder.

Nesse sentido, pode-se sustentar que, na área trabalhista, os deputados não são marginais no processo de formulação das políticas e o Executivo não legisla em detrimento do Legislativo. Esse achado caminha na mesma direção das conclusões apresentadas em estudos anteriores sobre a produção de políticas educacionais, agrícolas e de saúde (MARTINS, 2012; GOMES, 2011; LOPES, 2013), que indicam a relevância da atuação do Poder Legislativo na definição das políticas públicas. 


\section{6 - A TESE DO LEgislativo COMO ATOR ORIENTAdo PARA PRODUÇÃO DE POLÍTICAS PAROQUIAIS SOB EXAME}

Nesta seção busca-se verificar se há diferenças entre a agenda legislativa proposta pelos Poderes Executivo e Legislativo. A suposição é a de que a prevalência do "voto pessoal" no Brasil, conduziria a uma estratégia do ponto de vista do Legislativo mais voltada à perseguição e produção de políticas de nível de agregação local, voltadas à distribuição de benefícios para áreas geográficas específicas, coincidentes com os redutos eleitorais dos parlamentares. Já o Executivo, tendo em vista o sistema majoritário de seleção do chefe desse Poder, apresentaria propostas de âmbito nacional. Essa suposição, porém, não encontra apoio nos dados analisados, como pode-se observar na Tabela 5 .

Tabela 5- - Nível de agregação das propostas apresentadas na Câmara dos Deputados (2003-2014)

\begin{tabular}{ccc}
\hline Nível de agregação & Legislativo & Executivo \\
\hline Individual & 4 & 1 \\
Local & 2 & 1 \\
Setorial & 899 & 16 \\
Nacional & 530 & 14 \\
Simbólico & 21 & 1 \\
\hline Total & $\mathbf{1 . 4 5 6}$ & $\mathbf{3 3}$ \\
\hline
\end{tabular}

Fonte: elaborada pela autora (2015).

Os dois Poderes legislaram predominantemente no campo trabalhista em propostas setoriais, que se dirigem a grupos ou segmentos específicos da sociedade. Dos 1.456 projetos iniciados pelos deputados federais, $61,7 \%$ legislavam para setores ou segmentos específicos da sociedade (médicos, advogados, jovens, portadores de deficiência, mulheres, etc.), e dos 33 iniciados pelo Executivo, cerca de 48,5\% tinham a mesma orientação. Não houve preponderância de nenhum partido na proposição de projetos setoriais ou nacionais, já que todos eles indistintamente priorizaram propostas desses níveis de agregação territorial. 
Entre os projetos setoriais destacaram-se aqueles que versam sobre a segurança e saúde no trabalho (15\%), especialmente no que concerne à concessão de adicionais de periculosidade ou insalubridade para determinadas categoriais profissionais, a regulamentação de profissões (14,5\%), a duração da jornada de trabalho $(11,2 \%)$ e a modalidades de contrato $(10,15 \%)$.

Apesar de beneficiarem grupos ou segmentos específicos da sociedade e não a população de uma forma mais abrangente, pode-se sustentar que o impacto dos projetos setoriais é amplo, já que esses grupos dificilmente possuem suas estruturas e configuram suas ações apenas no âmbito local. Eles desejam o bem-estar de seus membros/categorias, que se encontram distribuídos em todo o território nacional (RICCI, 2006: 60) ${ }^{28}$.

O mesmo padrão de preferência se observa para o conjunto de projetos convertidos em lei, conforme demonstra a Tabela 6, abaixo.

(2003-2014)

Tabela 6- Nível de agregação das propostas transformadas em lei

\begin{tabular}{c|cc}
\hline Nível de agregação & Legislativo & Executivo \\
\hline Individual & - & 1 \\
Local & - & 1 \\
Setorial & 11 & 9 \\
Nacional & 7 & 10 \\
Simbólico & 4 & - \\
\hline Total & $\mathbf{2 2}$ & $\mathbf{2 1}$ \\
\hline
\end{tabular}

Fonte: elaborada pela autora (2015).

A julgar pelo diagnóstico corrente na literatura, era de se esperar que prevalecessem entre os projetos dos parlamentares aqueles classificados como locais. Esses, no entanto, foram minoria entre os projetos apresentados e os aprovados. Uma primeira questão pertinente, então, é: por que o paroquialismo dos deputados, decorrente

\footnotetext{
${ }^{28} \mathrm{O}$ autor entende os grupos de interesse, sumariamente, como organizações que representam interesses setoriais presentes num âmbito nacional. Médicos, enfermeiros, servidores públicos, militares, os ministérios públicos, bombeiros, professores, advogados, agricultores, metalúrgicos, etc., seriam, nesse sentido, exemplos de grupos potenciais, sendo necessário acrescentar a estes, ainda, as organizações e associações, não econômicas, que perseguem fins mais gerais, como a defesa dos direitos civis. É uma definição mínima que não discute o peso do tamanho do grupo, sua força organizacional, a capacidade de estruturar ações e as técnicas por eles adotadas para alcançar os fins.
} 
dos incentivos da arena eleitoral, não se reflete em sua produção legislativa na área trabalhista/sindical?

Lemos (2001:576-577) chama a atenção para o fato de que o poder do Congresso para propor leis que beneficiem regiões e clientelas específicas é bastante limitado. Existem barreiras constitucionais que os impedem de fazê-lo.

Primeiro, a prerrogativa de propor medidas de política econômica é delegada ao Poder Executivo. Conforme a Constituição Federal os parlamentares estão privados de apresentar propostas ordinárias que importem aumento ou diminuição da receita ou da despesa pública não previstos no plano plurianual, na lei de diretrizes orçamentárias e no orçamento anual, sendo competência exclusiva do Executivo a iniciativa dessas leis orçamentárias (artigo 165 da Constituição). Essa situação limita a capacidade dos deputados de transferir recursos para suas clientelas por meio de projetos de lei ordinária. Por conseguinte, nas áreas de política pública em que os deputados têm liberdade para legislar há poucas oportunidades de obter verbas e projetos de interesse localizado. Para os deputados federais que queiram beneficiar seus distritos, a arena orçamentária conforma-se como um espaço com melhor oportunidade de obter verbas públicas para localidades específicas.

E segundo, a pesar de não haver muitas restrições formais quanto à apresentação pelos deputados federais de projetos de lei ${ }^{29}$, o fato é que há limitação quanto ao conteúdo dos projetos. Conforme o art. 24, § 1º da Constituição de 1988 "no âmbito da legislação concorrente, a competência da União limitar-se-á a estabelecer normas gerais". Nesse sentido, matéria legislativa que teve origem no Congresso Nacional deve ter característica de norma geral.

Considerando as limitações ao favorecimento de uma determinada região por meio de proposições legislativas, os parlamentares atuariam como intermediadores das demandas setores específicos, tendo em vista a prevalência de matérias setoriais entre as propostas parlamentares. Nesse sentido, outra questão que se faz relevante é: por que os parlamentares beneficiam na produção legislativa grupos e segmentos específicos, contrariando a constatação, contra intuitiva, de que voto pessoal deriva uma tendência à produção de normas paroquiais, que direcionam benefícios apenas ao reduto eleitoral do

\footnotetext{
${ }^{29}$ As limitações são, no geral, técnicas. Conforme o Regimento Interno da Câmara dos Deputados (artigo 100), toda proposição deverá ser redigida com clareza, em termos explícitos e concisos, e apresentada em três vias, bem como não poderá conter matéria estranha ao enunciado objetivamente declarado na ementa, ou dele decorrente.
} 
parlamentar? O fato é que interesses e demandas setoriais são representados por grupos organizados que atuam tanto na arena eleitoral quanto na arena congressual, contam no cálculo político e moldam a performance dos parlamentares.

Frente à alta complexidade das questões políticas e frente à grande dificuldade de compatibilizar tempo e obtenção de informações sobre o que acontece na política, os eleitores recorrem aos grupos como uma forma de receber informações mais facilmente. Os grupos estão, por sua natureza, mais atentos e informados acerca do acontece no ambiente político e dentro da arena legislativa, enquanto os eleitores medianos, normalmente, estão desinformados e não sabem que maneiras alternativas de alcançar suas metas estão abertas e quais as consequências prováveis da escolha de cada alternativa. Por isso, eles frequentemente selecionam as fontes das quais receberão as informações que precisam para orientar suas escolhas.

Nesse sentido, os eleitores e as preferências por eles formuladas se tornam, em grande medida, influenciáveis pelos grupos de interesse. Os grupos não podem, por tanto, ser negligenciados pelos políticos, na medida em que são eles grandes conformadores e mobilizadores da opinião pública.

Outro fator responsável pelo fato de os parlamentares beneficiarem os grupos, por vezes até em detrimento de suas circunscrições eleitorais, é a eficácia e continuidade no tempo das pressões e cobranças vindas dos grupos, quando comparadas com as que provêm dos eleitores individuais. Eles, por meio das técnicas e atividades que desenvolvem, têm uma capacidade maior de avaliar os custos e benéficos de um projeto de lei, de monitorar a sua tramitação e ação dos deputados nela envolvidos, bem como de intervir diretamente no processo decisório de modo a influenciar, dentre outras coisas, o conteúdo do projeto (RICCI, 2006: 57).

Outra razão pela qual os deputados direcionam a tomada de decisão em favor das forças organizacionais, apontada às vezes como a mais contundente, tem a ver com os custos da competição eleitoral. Em um contexto em que a disponibilidade de recursos é fator fundamental senão determinante para o sucesso eleitoral, já que são elevados os gastos para a organização e administração de uma campanha, os deputados se veem defrontados com a imperativa necessidade de encontrar financiadores capazes de arcar com esses custos. Assim, os políticos favorecem os grupos de interesse com a expectativa de que eles retribuam eleitoralmente os serviços prestados, seja pela obtenção 
direta de votos, seja pelo financiamento de campanha, que amplia significativamente as chances de sucesso eleitoral dos parlamentares (PEREIRA e MULLER, 2003: 763).

A literatura oferece, então, um conjunto de critérios para se pensar o comportamento dos parlamentares e os resultados do processo legislativo ordinário. Se aceitarmos os fundamentos teóricos da relação direta entre políticos e eleitores ("conexão eleitoral"), o resultado seria a produção de políticas paroquiais visando os interesses localizados e territorialmente delimitados. No entanto, se rejeitarmos o argumento e pensarmos nos limites institucionais ao individualismo dos políticos e em uma "conexão eleitoral" em outros termos, com base na presença dos grupos de interesse, os outputs, então, podem ser diferentes e, portanto, não voltados à distribuição de benefícios apenas ao reduto eleitoral do parlamentar. A representação se faz não só do ponto de vista geográfico, mas também dos interesses organizados.

Não se trata aqui, contudo, de apontar se são benéficas ou não as intervenções dos grupos de interesse e a consequente fruição de benefícios as suas categorias. Trata-se apenas de reconhecer sua legitimidade nas democracias representativas e seu impacto sobre a distribuição de benefícios pelo Congresso e sobre as opções de políticas dos deputados.

Tendo em vista esse cenário, a ideia aqui defendida é que há uma espécie de divisão de trabalho dentro da Câmara dos Deputados. Por meio da atividade de execução de emendas ao orçamento ${ }^{30}$, os parlamentares atendam aos interesses localistas de seus redutos. Já por meio do acompanhamento das indicações dos líderes nas votações nominais em Plenário, os parlamentares atendam aos interesses de seus partidos, e por que não dizer do governo. E, por meio da apresentação de projetos de lei, especialmente os ordinários, os parlamentares atendam, essencialmente, aos interesses dos grupos organizados.

\section{1 - Conclusão}

O levantamento realizado nesta seção não permitiu sustentar a segunda hipótese central dessa pesquisa, qual seja: a de que as escolhas dos parlamentares em

\footnotetext{
30 Outras atividades como apresentação de projetos de decreto legislativo de concessão de canais de televisão e rádio (Araújo, 2008:220) e indicações ao Poder Executivo também têm o condão de concentrar benefícios em localidades geográficas específicas.
} 
termos de políticas na área trabalhista e sindical seria guiada por uma lógica, decorrente da arena eleitoral, que prioriza projetos de cunho local, destinados a beneficiar interesses geograficamente circunscritos.

Conforme os dados apresentados, predominam entre os projetos propostos pelos deputados aqueles de nível setorial, que visam beneficiar grupos ou segmentos específicos da sociedade, com efeito difuso e não concentrado sobre o território nacional. Os dados confirmaram o que outros estudos já vinham demonstrando, no sentido de que os parlamentares, em suas iniciativas na área trabalhista/sindical, não estiveram voltados para a satisfação de interesses paroquiais (LEMOS, 2001; MARTINS, 2012; LEMOS \& RICC, 2004; RICCI, 2002, 2003, 2004).

A não prevalência de projetos de nível local na produção legislativa dos deputados federais deve-se, entre outros fatores, a limitações constitucionais e à atuação de grupos organizados. 


\section{7 - CONSIDERAÇÕES FINAIS}

As análises sobre as políticas públicas na literatura especializada se concentram nas etapas de implementação e avaliação das políticas em termos de seus impactos sociais. Mesmo quando considerada nas pesquisas, a elaboração dos projetos que definem os contornos das políticas é vista como uma etapa dominada pelo Executivo. Este trabalho teve como objetivo, então, contribuir com essas análises ao acrescentar à discussão a participação do Poder Legislativo na elaboração das políticas e o seu modo de relacionamento com o Poder Executivo. Para tanto, investigou a atuação dos deputados federais na formulação das políticas trabalhistas e sindicais.

O Poder Legislativo detém, entre outras, a responsabilidade de produzir as leis que definem as linhas gerais da atuação governamental. Dessa função participa o Poder Executivo, que também possui a iniciativa das leis, além de ter a prerrogativa de sanção ou veto aos projetos apresentados pelo Legislativo. O Executivo controla, no entanto, uma série de recursos de poder (edição de Medida Provisória com força de lei, exclusividade na iniciativa de projetos de lei que tratem do orçamento e da organização da administração federal, possibilidade de solicitar urgência a determinados projetos de sua autoria, entre outros), que tornam a sua agenda predominante durante o trâmite legislativo. Esse domínio do Executivo na produção das leis coloca uma importante questão acerca do grau de autonomia que dispõe o Legislativo para vir a desempenhar sua função de produção normativa e conduzir, de certa maneira, as políticas públicas.

Não obstante as afirmações de que o Legislativo é um ator fraco, que não participa decisivamente da elaboração das leis, mas apenas homologa as iniciativas do Executivo, esta pesquisa concluiu que, para área das políticas trabalhistas e sindicais, os legisladores brasileiros têm desempenhado um papel ativo na conformação das normas. O Legislativo garantiu a aprovação de matérias de sua autoria sobre temas significativos e contribuiu de forma substancial com os textos finais dos projetos do Executivo, por meio dos mecanismos de emendamento e negociação.

Os deputados federais aprovaram, em números absolutos, mais projetos do que o Executivo, ainda que tenham sido proporcionalmente menos produtivos do que o Executivo. Além disso, como foi possível verificar, $66 \%$ dos projetos originados no Executivo foram aprovados com emendas ou na forma de um substitutivo ou de um projeto de lei de conversão. No total, os legisladores foram responsáveis por cerca de $31 \%$ 
dos dispositivos das leis trabalhistas do Executivo no período analisado. É evidente que houve propostas de emendas dos parlamentares que foram rejeitadas, seja nas comissões, seja no Plenário da Câmara, no entanto, os legisladores conseguiram interferir nos projetos do governo que tramitavam. Assim, apesar de o Executivo concentrar a iniciativa de legislação para diversos temas estruturantes, o fato é que ele não definiu sozinho o conteúdo das políticas.

Observou-se que a quantidade de projetos apresentados pelos parlamentares foi volumosa, mesmo sabendo que a maioria dessas proposições termina seu curso no arquivo. A existência desses projetos, portanto, tem cumprido papel de sinalizar aos eleitores do parlamentar autor o seu comprometimento com determinada causa ou demanda.

O Legislativo não funcionou como um obstáculo intransponível ao avanço de reformas ou da agenda pretendida pelo Executivo, já que, apesar de haver projetos rejeitados ou "engavetados", a maioria das proposições trabalhistas que compunha a agenda governamental foi transformada em norma.

Quanto aos partidos políticos, verificou-se uma maior preferência entre os partidos de esquerda no espectro político-ideológico por projetos trabalhistas/sindicais.

Diversos foram os assuntos propostos, a sua agregação em categorias temáticas indicou que a preocupação mais recorrente foi com processos judiciais trabalhistas, tanto por parte dos parlamentares quanto por parte do Executivo.

Com relação à afirmação do predomínio da atuação parlamentar orientada para a produção de políticas públicas voltada ao atendimento de interesses paroquiais, compatíveis com os dos distritos eleitorais dos deputados, esta pesquisa concluiu, para seara trabalhista/sindical, que a ação legislativa tem sido direcionada ao atendimento de demandas setoriais, de grupos difusos e não concentrados territorialmente. A lógica da predominância de uma atividade parlamentar paroquial, decorrente dos incentivos ao "voto pessoal", funciona para arena orçamentária. Para a arena legislativa stricto sensu essa lógica não se aplica, tendo em vista a existência de normas constitucionais que limitam a produção de leis de cunho local.

A predominância de projetos setoriais na produção das políticas trabalhistas e sindicais remete à discussão sobre a atuação dos grupos de interesse e de representações de classe nestas políticas. É preciso, ainda, aprofundar os estudos sobre a 
conexão entre os parlamentares e esses segmentos organizados. Essa é uma agenda para pesquisas futuras.

Dialogando com outros estudos relativos ao tema, resta dizer que estas conclusões reforçam os trabalhos que indicam a relevância da atuação do Poder Legislativo na definição de políticas públicas específicas (MARTINS, 2012; GOMES, 2010; LOPES, 2013) e o comprometimento dos parlamentares com políticas mais amplas em oposição às paroquiais (LEMOS, 2001; MARTINS, 2012; LEMOS \& RICC, 2004; RICCI, 2002, 2003, 2004).

Este trabalho evidencia, assim, a amplitude da atividade legislativa e possibilita desvendar, em alguma medida, as intrincadas relações existentes na formulação das políticas públicas, as complexas práticas do Legislativo, bem como os limites e oportunidades para ação do Legislativo na aprovação de leis referentes aos direitos trabalhistas e sindicais.

Por fim, há que se reconhecer ainda as limitações desta análise, bem como as possibilidades existentes para estudos vindouros. Não se explorou nesta pesquisa a dinâmica das interações operadas entre o Legislativo e o Executivo, bem como entre estes e os grupos organizados, no âmbito da Comissão de Trabalho e Administração Pública (CTASP). Estudos com esse propósito podem ser reveladores, já que boa parte das proposições legislativas trabalhistas de autoria dos deputados sancionadas no período estudado foram aprovadas em caráter conclusivo, ou seja, sem anuência do Plenário. $\mathrm{O}$ que poderia também render resultados importantes seria o estudo das interferências efetuadas pelo Executivo, por meio da atuação das assessorias parlamentares dos órgãos governo e dos deputados de sua base aliada, nas propostas dos congressistas, o que não foi abordado nesta pesquisa. Não se pode deixar de mencionar a possibilidade da realização de estudos desta natureza para outras áreas de políticas, o que poderá lustrar variações institucionais que não foram capturados neste estudo. 


\section{ANEXO I}

\section{Exemplos de tipos de projeto por área temática}

\begin{tabular}{|c|c|c|}
\hline Tema & Descrição & Exemplos \\
\hline Benefícios & $\begin{array}{l}\text { Tratam do vale-transporte, ticket, } \\
\text { seguro de vida, vale-cultura, etc. }\end{array}$ & $\begin{array}{l}\text { PL } 5798 / 2009 \text { que institui o Programa de Cultura } \\
\text { do Trabalhador, cria o Vale-Cultura e dá outras } \\
\text { providências. }\end{array}$ \\
\hline $\begin{array}{l}\text { Demissão e rescisão de } \\
\text { contrato/estabilidade }\end{array}$ & $\begin{array}{l}\text { Tratam sobre as condições para } \\
\text { dispensa de empregado, direitos a } \\
\text { receber em caso demissão e situações } \\
\text { que garantem estabilidade ou } \\
\text { permanência no emprego. }\end{array}$ & $\begin{array}{l}\text { PL 5936/2009 que altera a redação da } \\
\text { Consolidação das Leis do Trabalho - CLT, } \\
\text { aprovada pelo Decreto-Lei no } 5.452 \text {, de } 1^{\circ} \text { de maio } \\
\text { de } 1943 \text {, para vedar a dispensa arbitrária ou sem } \\
\text { justa causa do trabalhador cuja esposa ou } \\
\text { companheira gestante não goze do mesmo } \\
\text { benefício. }\end{array}$ \\
\hline $\begin{array}{l}\text { Apoio } \\
\text { desempregado/seguro- } \\
\text { desemprego }\end{array}$ & $\begin{array}{l}\text { Tratam das políticas de seguro- } \\
\text { desemprego, do Fundo de Amparo ao } \\
\text { trabalhados (FAT) e outros benefícios } \\
\text { a serem concedidos a pessoa } \\
\text { desempregada. }\end{array}$ & $\begin{array}{l}\text { PL } 5857 / 2005 \text { que altera a Lei } \mathrm{n}^{\circ} 10.779 \text {, de } 25 \text { de } \\
\text { novembro de } 2003 \text {, para estender a concessão do } \\
\text { benefício do seguro-desemprego aos trabalhadores } \\
\text { na extração ou beneficiamento artesanal do açaí e } \\
\text { castanha do Pará. }\end{array}$ \\
\hline $\begin{array}{ll}\text { Situações } & \text { de } \\
\text { afastamento/licenças } & \end{array}$ & $\begin{array}{l}\text { Estendem os casos em que será } \\
\text { possível ao trabalhador faltar ao } \\
\text { trabalho, sem prejuízo do salário, bem } \\
\text { como das licenças-paternidade, } \\
\text { maternidade, adotante e nojo. }\end{array}$ & $\begin{array}{l}\text { PL } 711 / 2007 \text { que concede ao trabalhador brasileiro } \\
\text { um dia de folga remunerada no dia do seu } \\
\text { aniversário. }\end{array}$ \\
\hline $\begin{array}{l}\text { Homenagens e datas } \\
\text { comemorativas }\end{array}$ & Fixam datas comemorativas. & $\begin{array}{l}\text { PL 5192/2013 que institui o "Dia Nacional do } \\
\text { Trabalho Decente", a ser realizada anualmente no } \\
\text { dia } 7 \text { de outubro. Explicação: Valoriza a dignidade } \\
\text { do trabalho. }\end{array}$ \\
\hline $\begin{array}{l}\text { Discriminação no mercado } \\
\text { de trabalho }\end{array}$ & $\begin{array}{l}\text { Tratam sobre práticas discriminatórias } \\
\text { para ingresso no mercado de trabalho } \\
\text { ou dentro do ambiente de trabalho. }\end{array}$ & $\begin{array}{l}\text { PEC 114/2011 que garante aos trabalhadores } \\
\text { domésticos os mesmos diretos trabalhistas } \\
\text { elencados na Constituição Federal conferidos aos } \\
\text { trabalhadores urbanos e rurais. }\end{array}$ \\
\hline Duração do trabalho & $\begin{array}{l}\text { Tratam sobre a jornada de trabalho, o } \\
\text { tempo de deslocamento que o } \\
\text { trabalhador despende até o trabalho e } \\
\text { o intervalo intrajornada. }\end{array}$ & $\begin{array}{l}\text { PL } 2409 / 2011 \text { que "Altera os } \$ \$ 2 \text { o e } 3 \text { o do art. } 58 \\
\text { da Consolidação das Leis do Trabalho (CLT), } \\
\text { aprovada pelo Decreto-lei no } 5.452 \text {, de } 1 \text { o de maio } \\
\text { de 1943, a fim de dispor que o tempo de } \\
\text { deslocamento do empregado até o local de trabalho } \\
\text { e para o seu retorno não integra a jornada de } \\
\text { trabalho" }\end{array}$ \\
\hline $\begin{array}{l}\text { Processos } \\
\text { trabalhistas }\end{array}$ & $\begin{array}{l}\text { Tratam sobre as decisões, os } \\
\text { processos e as competências na Justiça } \\
\text { do Trabalho, bem como sobre a } \\
\text { resolução de conflitos trabalhistas e a } \\
\text { arbitragem. }\end{array}$ & $\begin{array}{l}\text { PL } 5347 / 2010 \text { que estabelece que decorridos oito } \\
\text { anos de tramitação do processo trabalhista sem que } \\
\text { a ação tenha sido levada a termo o processo será } \\
\text { extinto, com julgamento de mérito por decurso de } \\
\text { prazo. }\end{array}$ \\
\hline Modalidade de contratos & $\begin{array}{l}\text { Tratam das modalidades de } \\
\text { contratação diferenciada, a fim de } \\
\text { diminuir a informalidade (contrato de } \\
\text { estágio, aprendiz, trabalho } \\
\text { temporário, contrato de experiência, } \\
\text { contrato por prazo determinado, etc.) }\end{array}$ & $\begin{array}{l}\text { PL } 3587 / 2012 \text { que institui o contrato de trabalho } \\
\text { intermitente. }\end{array}$ \\
\hline $\begin{array}{l}\text { Negociação } \\
\text { coletiva/acordos } \\
\text { convenções }\end{array}$ & $\begin{array}{l}\text { Tratam sobre os procedimentos e } \\
\text { regras para negociações, acordos e } \\
\text { convenções coletivas, em alguns } \\
\text { casos, estabelecendo a prevalência } \\
\text { desse sobre o legislado (flexibilização } \\
\text { da CLT). }\end{array}$ & $\begin{array}{l}\text { PEC 129/2003 que altera o art. } 37 \text { da Constituição } \\
\text { Federal estendendo o direito à negociação coletiva } \\
\text { aos servidores públicos. }\end{array}$ \\
\hline
\end{tabular}




\begin{tabular}{|c|c|c|}
\hline $\begin{array}{lll}\text { Organização } & \text { sindical } & \mathrm{e} \\
\text { contribuição } & & \end{array}$ & $\begin{array}{l}\text { Tratam sobre o Direito coletivo do } \\
\text { trabalho, especificando regras sobre a } \\
\text { representação dos trabalhadores e } \\
\text { sobre o recolhimento da contribuição } \\
\text { sindical. }\end{array}$ & $\begin{array}{l}\text { PEC 314/2004 que dispõe sobre a Organização } \\
\text { Sindical e dá outras providências. }\end{array}$ \\
\hline Política salarial & $\begin{array}{l}\text { Dispõem sobre reajuste salarial, } \\
\text { instituição de piso salarial, salário } \\
\text { mínimo, retenção de salários, etc. }\end{array}$ & $\begin{array}{l}\text { PL } 628 / 2003 \text { que altera o art. } 10 \text { da Lei } n^{\circ} 10.192 \text {, } \\
\text { de } 14 \text { de fevereiro de } 2001 \text {, a fim de estabelecer o } \\
\text { reajuste anual dos salários conforme a variação do } \\
\text { Índice Nacional de Preços ao Consumidor. }\end{array}$ \\
\hline $\begin{array}{l}\text { Regulamentação } \quad \text { de } \\
\text { profissões }\end{array}$ & $\begin{array}{l}\text { Fixam benefícios (duração máxima da } \\
\text { jornada, aposentadoria especial, piso } \\
\text { salarial) para categorias profissionais } \\
\text { especificas, além de estabelecerem } \\
\text { requisitos técnicos ou de formação } \\
\text { para exercício da atividade. }\end{array}$ & $\begin{array}{l}\text { PL 6399/2005 que dispõe sobre a profissão de } \\
\text { Fotógrafo e dá outras providências. }\end{array}$ \\
\hline $\begin{array}{llll}\text { Segurança } & \text { e } & \text { saúde } & \text { no } \\
\text { trabalho } & & & \end{array}$ & $\begin{array}{l}\text { Tratam das obrigações das empresas } \\
\text { quanto a segurança e saúde dos } \\
\text { empregados no ambiente de trabalho, } \\
\text { abordando temas como doenças } \\
\text { ocupacionais e acidentes de trabalho. } \\
\text { Também versam sobre as atividades } \\
\text { consideradas penosas, insalubres ou } \\
\text { perigosas. }\end{array}$ & $\begin{array}{l}\text { PL } 7206 / 2010 \text { que "Altera o caput e revoga os } \S \S \\
\text { 1o e } 2 \text { o do art. } 21 \text {-A da Lei no } 8.213 \text {, de } 24 \text { de julho } \\
\text { de } 1991 \text {, para dispor sobre a inclusão do critério } \\
\text { epidemiológico de caracterização da natureza } \\
\text { acidentaria da incapacidade, no estabelecimento do } \\
\text { nexo causal entre o trabalho e o agravo". }\end{array}$ \\
\hline $\begin{array}{l}\text { Direito humanos/trabalho } \\
\text { escravo ou degradante }\end{array}$ & $\begin{array}{l}\text { Tratam da proteção e valorização dos } \\
\text { direitos humanos nas relaçôes de } \\
\text { trabalho, versando, por exemplo, } \\
\text { sobro trabalho escravo }\end{array}$ & $\begin{array}{l}\text { PL 2922/208, que institui selo nacional para as } \\
\text { empresas que não cometam o crime de redução a } \\
\text { condição análoga à de escravo. } \\
\text { PL 2398/2007 que dispõe sobre o fim do trabalho } \\
\text { infantil. }\end{array}$ \\
\hline Tributação & $\begin{array}{l}\text { Trata sobre os tributos incidentes } \\
\text { sobre a folha de salários ou sobre as } \\
\text { deduções e isenções tributárias para o } \\
\text { empregador ou empregado nos casos } \\
\text { que especificam. }\end{array}$ & $\begin{array}{l}\text { PL 5707/2013, que dispõe sobre redução de } \\
\text { encargos tributários na contratação de } \\
\text { trabalhadores com idade igual ou superior a } \\
\text { sessenta anos e de jovens para o primeiro emprego. } \\
\text { PL } 1186 / 2011 \text { que estabelece isenção do imposto } \\
\text { de renda sobre abono salarial, participação dos } \\
\text { trabalhadores nos lucros ou resultados da empresa } \\
\text { e adicional de um terço de férias, nos termos que } \\
\text { especifica, e dá outras providências. }\end{array}$ \\
\hline $\begin{array}{l}\text { Qualificação } \\
\text { trabalhador }\end{array}$ & $\begin{array}{l}\text { Tratam sobre a qualificação e } \\
\text { capacitação professional. }\end{array}$ & $\begin{array}{l}\text { PL } 1836 / 2003 \text { que acrescenta ao art. } 429 \text { da } \\
\text { Consolidação das Leis do Trabalho - CLT, } \\
\text { aprovada pelo Decreto-lei } n^{\circ} 5.452 \text {, de } 1^{\circ} \text { de maio } \\
\text { de } 1943 \text {, os parágrafos } 2^{\circ} \text { ao } 6^{\circ} \text {, fixando penalidade } \\
\text { e dá outras providências. Explicação: Fixa multa } \\
\text { para a empresa que descumprir a exigência de } \\
\text { matricular, em cursos do SENAI, seus } \\
\text { empregados. }\end{array}$ \\
\hline Outros & $\begin{array}{l}\text { Inclui os projetos que tratam sobre } \\
\text { cooperativas de trabalho, direito de } \\
\text { greve, administração pública, férias, } \\
\text { participação nos lucros (PLR), } \\
\text { anotações em carteira de trabalho e } \\
\text { FGTS (flexibilização quanto ao saque, } \\
\text { mecanismos de correção, controle } \\
\text { sobre o recolhimento dos depósitos, } \\
\text { etc.). }\end{array}$ & $\begin{array}{l}\text { PL 2312/2011 que "Altera normas relativas ao } \\
\text { Fundo de Garantia do Tempo de Serviço". }\end{array}$ \\
\hline
\end{tabular}




\section{ANEXO II \\ Distribuição temática dos projetos conforme orientação ideológica do partido (tamanho médio da bancada nas três legislaturas analisadas)}

\begin{tabular}{|c|c|c|c|}
\hline \multirow[t]{2}{*}{ Área temática } & \multicolumn{3}{|c|}{ Orientação ideológica do partido } \\
\hline & Centro & Direita & Esquerda \\
\hline Modalidade de contratos & 0,159722222 & 0,15372409 & 0,229486175 \\
\hline Inclusão no mercado de trabalho & 0,069444444 & 0,109094516 & 0,100750028 \\
\hline Terceirização & 0,041666667 & 0,009917683 & 0,072763909 \\
\hline Política salarial & 0,104166667 & 0,079341466 & 0,179111161 \\
\hline Processos judiciais trabalhistas & 0,25 & 0,168600615 & 0,29665286 \\
\hline Demissão e rescisão de contrato/estabilidade & 0,159722222 & 0,104135674 & 0,212694504 \\
\hline Regulamentação de profissões & 0,194444444 & 0,143806407 & 0,408597336 \\
\hline Segurança e saúde no trabalho & 0,229166667 & 0,203312506 & 0,492555692 \\
\hline Direitos humanos/trabalho escravo ou degradante & 0,055555556 & 0,084300307 & 0,156722266 \\
\hline Apoio ao desempregado/seguro-desemprego & 0,138888889 & 0,114053357 & 0,145527818 \\
\hline Situações de afastamento/licenças & 0,180555556 & 0,119012199 & 0,20709728 \\
\hline Discriminação no mercado de trabalho & 0,055555556 & 0,024794208 & 0,184708385 \\
\hline Duração do trabalho & 0,180555556 & 0,188435981 & 0,363819546 \\
\hline Negociação coletiva/acordos e convenções & 0,048611111 & 0,059506099 & 0,08955558 \\
\hline Organização sindical e contribuição & 0,048611111 & 0,069423783 & 0,201500056 \\
\hline Qualificação do trabalhador & 0,0625 & 0,02975305 & 0,095152804 \\
\hline Benefícios sociais & 0,090277778 & 0,119012199 & 0,16231949 \\
\hline Homenagens e datas comemorativas & 0,020833333 & 0,039670733 & 0,055972238 \\
\hline Tributação & 0,111111111 & 0,099176832 & 0,156722266 \\
\hline Outros* & 0,1111 & 0,133889 & 0,2015 \\
\hline
\end{tabular}

Fonte: elaborado pela autora (2015).

* Enquadram-se nessa categoria os projetos que versam sobre: administração pública (13), cooperativas de trabalho (12), direito de greve (6), FGTS (17), carteira de trabalho (10), participação nos lucros (7) e férias (14). 


\section{ANEXO III}

\section{Exemplo de classificação de projetos de lei, conforme nível de agregação}

\begin{tabular}{|c|c|c|}
\hline $\begin{array}{l}\text { Identificação } \\
\text { do projeto }\end{array}$ & Ementa & $\begin{array}{l}\text { Agregação } \\
\text { Territorial }\end{array}$ \\
\hline PL 33/2007 & Dispõe sobre o assédio moral nas relações de trabalho. & \multirow[t]{2}{*}{ Nacional } \\
\hline PL 2214/2011 & $\begin{array}{l}\text { Dispõe sobre o processamento de recursos no âmbito da Justiça do } \\
\text { Trabalho }\end{array}$ & \\
\hline PL 6343/2009 & $\begin{array}{l}\text { Garante o pagamento do adicional de insalubridade aos fotógrafos, } \\
\text { operadores de câmeras de cinema e televisão e trabalhadores }\end{array}$ & \multirow[t]{2}{*}{ Setorial } \\
\hline PL 1996/2011 & $\begin{array}{l}\text { Altera a Lei n. } .^{\circ} 4.119 \text {, de } 27 \text { de agosto de 1962, para dispor sobre a } \\
\text { jornada de trabalho dos psicólogos. }\end{array}$ & \\
\hline PL 2000/2011 & $\begin{array}{l}\text { Concede anistia aos trabalhadores rurais de Rondônia punidos no } \\
\text { episódio conhecido como "Massacre de Corumbiara". }\end{array}$ & \multirow[t]{2}{*}{ Local } \\
\hline PL 6066/2013 & $\begin{array}{l}\text { Dispõe sobre a concessão do benefício de seguro-desemprego, } \\
\text { durante o período de entressafra, ao trabalhador na atividade de cata } \\
\text { e de beneficiamento artesanal do coco da Bahia. }\end{array}$ & \\
\hline PL 4973/2009 & $\begin{array}{l}\text { Concede a indenização e tratamento médico aos trabalhadores da } \\
\text { extinta Sucam, atual Funasa, contaminados pelos inseticidas DDT e } \\
\text { Malathion. }\end{array}$ & \multirow[t]{3}{*}{ Individual } \\
\hline Pl 343/2007 & $\begin{array}{c}\text { Assegura reintegração aos trabalhadores do Banco do Nordeste do } \\
\text { Brasil - BNB demitidos no período de } 1995 \text { a } 2003 .\end{array}$ & \\
\hline Pl 331/2003 & $\begin{array}{c}\text { Concede indenização ao Sr. José Pereira Ferreira por haver sido } \\
\text { submetido à condição análoga à de escravo e haver sofrido lesões } \\
\text { corporais, na fazenda "Espírito Santo", no Sul do Estado do Pará, em } \\
\text { setembro de } 1989 .\end{array}$ & \\
\hline PL 5540/2005 & $\begin{array}{l}\text { Institui o Dia Nacional dos Trabalhadores em Radiologia. Explicação: } \\
\text { A ser comemorado no dia } 29 \text { de outubro. }\end{array}$ & \multirow[t]{2}{*}{ Simbólico } \\
\hline PL 7059/2006 & $\begin{array}{l}\text { Institui o Dia Nacional do Sindicalista. Explicação: A ser comemorado } \\
\text { no dia } 6 \text { de janeiro. }\end{array}$ & \\
\hline
\end{tabular}

Fonte: elaborada pela autora (2015). 


\section{REFERÊNCIA BIBLIOGRÁFICA}

ABRANCHES, Sérgio. Presidencialismo de Coalizão: O Dilema Institucional Brasileiro. Dados, vol. 31, no 1, 1988 (p. 5-33).

ALMEIDA, Acir; LOPEZ, Félix. Representação política local: padrões de atuação dos vereadores em quatro cidades mineiras. IPEA: textos para discussão $\mathrm{n}^{\circ} 1625$, junho de 2011.

AMARAL, Ana Regina Villar Peres. O parlamento brasileiro processo, produção e organização legislativa: o papel das comissões em perspectiva comparada, 2009.

AMES, Barry. The Deadlock of Democracy in Brazil: Interests, Identities, and Institutions in Comparative Politics. Ann Arbor: The University of Michigan Press, 2001.

Electoral rules, Constituency Pressures, and pork barrel: bases of voting in the Brazilian Congress. The Journal of Politics, vol. 57, nº 2, may 1995 (p.324 - 343).

AMORIM NETO, Octávio e SANTOS, Fabiano. O Segredo Ineficiente Revisto: $O$ que Propõem e o que Aprovam os Deputados Brasileiros. Dados, vol. 46, nº 4, 2003 (p. 661698).

AMORIM NETO, Octavio. Gabinetes Presidenciais, Ciclos Eleitorais e Disciplina Legislativa no Brasil. Dados, vol. 43, no 3, 2000 (p. 479-519).

ARAÚJO, Paulo Magalhães. A Câmara Alta no presidencialismo brasileiro: $o$ desempenho legislativo do Senado entre 1989 e 2000. In: LEMOS, Leany Barreiro de S. O Senado Federal brasileiro no pós-Constituinte. Brasília : Senado Federal, Unilegis, 2008 (p. 203-236).

ARNOLD, Douglas R. The Logic of Congressional Action. New Haven \& London, Yale University Press, 1990.

ASHWORTH, Scott e BUENO, Ethan. Delivering the Goods: Legislative Particularism in Different Electoral and Institutional Settings. The Journal of Politics, vol. 68, $\mathrm{n}^{\circ} .1$, fevereiro, 2006 (p. 168-179)

BARRETO, Vicente. Voto e Representação, In: Curso de Introdução à Ciência Política, Brasília: Editora Universidade de Brasília, 1984. 
BORGES, André. Federalismo, dinâmica eleitoral e políticas públicas no Brasil: uma tipologia e algumas hipóteses. Sociologias, porto Alegre, ano 12, 2012 (p. 120 - 157).

Brasil. Constituição Federal, 1988.

. Regimento Interno da Câmara dos Deputados, 1989.

- Câmara dos Deputados. Pesquisa de Proposições. Disponível em: http://www.camara.gov.br/sileg/default.asp.

Superior Tribunal Eleitoral - TSE. Disponível em: www.tse.gov.br/

CARREIRÃO, Yan de Souza. Ideologia e partidos políticos: um estudo sobre coligações em Santa Catarina. OPINIÃO PÚBLICA, Campinas, vol. 12, nº 1, Abril/Maio, 2006 (p. 136-163).

CARVALHO, Nelson Rojas de. E no início eram as bases - Geografia política do voto e comportamento legislativo no Brasil. Rio de Janeiro: Revan, 2003.

CERVI, Emerson Urizzi. Produção legislativa e Conexão eleitoral na Assembléia Legislativa do Estado do Paraná. Revista de Sociologia e Política, Curitiba, vol. 17, $\mathrm{n}^{\circ}$ 32, 2009 (p. 159-177).

COX, Gary W. The Efficient Secret: The Cabinet and the Development of Political Parties in Victorian England. Cambridge, Cambridge University Press, 1987.

CRUZ, Márcia Rodrigues. Legislativo transformador? As modificações do Legislativo nos projetos de lei do Executivo. Dissertação de Mestrado, Rio de Janeiro, Instituto Universitário de Pesquisas do Rio de Janeiro/Centro de Formação da Câmara dos Deputados, 2009.

DA SILVA, Marcelo Gonçalves. Cabos de Guerra e Políticas Públicas no Brasil: Estudo de caso do Processo Decisório da Reforma Sindical (2003-2006). Tese de mestrado apresentada na Universidade de Brasília, 2007.

DE CASTRO, Mônica Mata Machado; ANASTASIA, Fátima; NUNES, Felipe. Determinantes do Comportamento Particularista de Legisladores Estaduais Brasileiros. DADOS, Rio de Janeiro, vol. 52, nº 4, 2009 (p. 961-1001).

DIAP. Agenda Legislativa dos Trabalhadores no Congresso Nacional, 2014. Disponível em: http://www.diap.org.br/. Último acesso em 20/11/2015. 
DINIZ, Simone. Interações entre os poderes Executivo e Legislativo no processo decisório: avaliando sucesso e fracasso presidencial. Dados: Revista de Ciências Sociais, Rio de Janeiro, v. 48, n. 1, 2004.

Presidencialismo(s) e seus efeitos no processo decisório: as mudanças na legislação do trabalho no Brasil e na Argentina. Tese de doutorado apresentada na Universidade de São Paulo, 2004.

EVANS, Diana. Greasing the Wheels: Using Pork Barrel Projects to Build Majority Coalitions in Congress. Cambridge University Press, 2004.

FLEISCHER, David. As eleições municipais no Brasil: uma análise comparativa (19822000). Opinião Pública, vol.8, nº 1, Campinas, 2002.

FIELD, Andy. Descobrindo a Estatística usando SPSS. Porto Alegre: Artmed, $2^{\mathrm{a}}$ Ed., 2009.

FIGUEIREDO, Argelina e LIMONGI, Fernando. Executivo e Legislação na Nova Ordem Constitucional. Rio de Janeiro, FGV, 1999.

. (1996), Congresso Nacional: organização, processo legislativo e produção legal. São Paulo, Cadernos de Pesquisas, 5, Cebrap.

$\mathrm{n}^{\circ} 2,2002$ (p. 303-344).

Incentivos Eleitorais, Partidos e Política Orçamentária. Dados, vol. 45, Modelos de Legislativo: o Legislativo brasileiro em perspectiva. Plenarium, Brasília, v. 1, n. 41, nov. 2004.

- Mudança constitucional, Desempenho do Legislativo e Consolidação Institucional. Revista Brasileira de Ciências Sociais, ano 10, nº 29, 1995 (p. 175-200).

FREITAS, Andréa. $O$ Legislativo na produção de políticas. In: $38^{\circ}$ Encontro Anual da ANPOCS, 2014, Caxambu. GT: Partidos e Sistemas Partidários do $38^{\circ}$ Encontro Anual da ANPOCS, 2014.

GIL, Antonio Carlos. Métodos e técnicas de pesquisa social. 5 ed. São Paulo: Atlas, 1999.

GOMES, Fábio de Barros Correia. Interações entre o Legislativo e o Executivo Federal do Brasil na definição de políticas de interesse amplo: uma abordagem sistêmica, com aplicação na saúde. Tese de Doutorado apresentada da Universidade Estadual do Rio de Janeiro, 2011. 
GOMES, Fábio de Barros Correia, DE CARVALHO, Eduardo Lopes e REIS, Rodolfo. Projetos de lei ordinária apresentados na Câmara dos Deputados entre 1999 e 2006: tramitação geral e dos relacionados à saúde. E-Legis, $\mathrm{n}^{\circ}$ 02, $1^{\circ}$ semestre, 2009 (p. 21 27).

HALL, Peter A., TAYLOR, Rosemary C. R.. As três versões do neo-institucionalismo. Lua Nova, n.58, 2003 (p.193-223).

KINZO, M. D. O quadro partidário e a constituinte. In: LAMOUNIER, B. (org.) De Geisel a Collor: o balanço da transição. São Paulo: IDESP / Sumaré, 1990.

KREIN, José D.; SANTOS, Anselmo Luis; NUNES, Bartira. Trabalho no governo Lula: avanços e contradições. Texto para Discussão, Unicamp, fev, 2012.

LEMOS, Leany Barreiro de S. O Congresso Brasileiro e a Distribuição de Benefícios Sociais no Período 1988-1994: Uma Análise Distributivista. Dados, Rio de Janeiro, vol. $44, \mathrm{n}^{\mathrm{o}} 3,2001$.

O Senado Federal brasileiro no pós-Constituinte. Brasília : Senado Federal, Unilegis, 2008 (p. 237-267).

LEONI, Eduardo, PEREIRA, Carlos e RENNÓ, Lúcio. Estratégias para sobreviver politicamente: Escolhas de carreiras na Câmara de Deputados do Brasil. Opinião Pública, Campinas, vol. IX, nº 1, 2003 (p. 44-67).

LOPES, Fábio Luiz. A participação do poder legislativo na elaboração de políticas públicas para o setor agrícola (2003-2010). Tese de Mestrado apresentada na Universidade do Paraná, 2013.

LOWI, Theodore. American business, public policy, case studies and political theory. World Politics, 16 jul. 1964.

Decision making vs. policy making: toward and antidote for technocracy. Public Administration Review, v. 30, n. 3, may./jun. 1970.

LUCCA, Juan Bautista. Estudio comparado de la identidad partidaria-sindical durante el gobierno de Lula da Silva (Brasil, 2003-2006) y de Néstor Kirchner (Argentina, 2003-2007). Phd. Dissertation in Social Sciences (Buenos Aires: Facultad Latinoamericana de Ciencias Sociales), 2011. 
MAINWARING, Scott. Rethinking Party Systems in the Third Wave of Democratization. The Case of Brazil. Stanford, Stanford University Press, 1999.

. Sistemas Partidários em Novas Democracias: O Caso do Brasil. Porto Alegre/Rio de Janeiro, Mercado Aberto/FGV, 2001.

MAINWARING, Scott; BEJARANO, Ana; LEONGOMEZ, Eduardo. The Crisis of Democratic Representation in the Andes. Stanford University Press, 2006 (204-223).

MARTINS, Ricardo Chaves de Rezende. O Poder Legislativo e as Políticas Públicas Educacionais no Período 1995-2010. Câmara dos Deputados, Edições Câmara, 2012.

MAYHEW, David R. Congress. The Electoral Connection. New Haven and London, Yale University Press, $2^{\text {a }}$ Ed, 2004.

MOREIRA, Cláudia Cristina Pacheco. Proposições de Iniciativa parlamentar: os projetos de lei apresentados no Senado entre 1987 e 2005. Tese de Mestrado apresentada no Instituto de Ciência Política da Universidade de Brasília, 2006.

MORAES, Alexandre de. Direito Constitucional. 16. ed. São Paulo: Atlas, 2004. p. 547.

NASCIMENTO, Amauri M. Limites constitucionais da liberdade no Brasil. In: OLIVEIRA, C.A. e outros. O mundo do trabalho: crise e mudanças no final do século. São Paulo: Cesit, 1994 (p. 323-358).

NICOLAU, Jairo M. Como controlar os representantes? Considerações sobre as eleições para a Câmara dos Deputados no Brasil. Dados, Rio de Janeiro, vol. 45, nº 2, 2002 (p. 219-236).

NORONHA, Eduardo Garuti. 2000. Entre a lei e a arbitrariedade: mercado e relações de trabalho no Brasil. São Paulo: LTr.

PASTORE, José. Reforma Trabalhista: $O$ que pode ser feito? Cadernos de Economia da FECOMERCIO, São Paulo, 2006.

PEREIRA, Carlos, e MULLER, Bernardo. Uma Teoria da Preponderância do Executivo: O Sistema de Comissões no Legislativo Brasileiro. Revista Brasileira de Ciências Sociais, São Paulo, vol.15, nº 43, 2000.

Comportamento Estratégico em Presidencialismo de Coalizão: As Relações entre Executivo e Legislativo na Elaboração do Orçamento Brasileiro. Dados, vol. 45, no 2, 2002 (p. 265-301). 
. Partidos fracos na arena eleitoral e partidos fortes na arena legislativa: a conexão eleitoral no Brasil. Dados, Rio de Janeiro, vol. 46, nº 4, 2003 (p. 735-771).

PEREIRA, Carlos e RENNÓ, Lucio. O que É que o Reeleito Tem? O esboço de uma teoria da reeleição no Brasil. Revista de Economia Política, agosto de 2006.

PITKIN, Hanna. The Concept of Representation. Berkeley : University of California, 1967.

RICCI, Paolo; LEMOS, Leany. Produção legislativa e preferências eleitorais na Comissão de Agricultura e Política Rural da Câmara Dos Deputados. RBCS Vol. 19 nº 55 junho/2004.

RICCI, Paolo. A medida das leis: do uso de noções genéricas à mensuração do imponderável. BIB, São Paulo, nº 54, 2002 (p. 101-123).

O Conteúdo da Produção Legislativa Brasileira: Leis Nacionais ou Políticas Paroquiais?. Dados, vol. 46, nº 4, 2003 (p. 699-734).

. De onde vêm nossas leis? Origem e conteúdo da legislação em perspectiva comparada. Tese de Doutorado apresentada no Departamento de Ciência Política da Faculdade de Filosofia, Letras e Ciências Humanas da Universidade de São Paulo, 2006.

- A produção legislativa de iniciativa parlamentar no Congresso brasileiro: diferenças e similaridades entre a Câmara dos Deputados e o Senado Federal. In: SAMUELS, David J. Pork Barreling Is Not Credit Claiming or Advertising: Campaign Finance and the Sources of the Personal Vote in Brazil. The Journal of Politics, vol. 64, $\mathrm{n}^{\circ} 3,2002$ (p. 845-863).

SAIEGH, Sebastian. Active Players or Rubber-Stamps? Assessing the Policy-Making Role of Latin American Legislatures. MPSA Annual National Conference, Chicago, 2008.

SANTOS, Fabiano. Patronagem e Poder de Agenda na Política Brasileira. Dados, Rio de Janeiro, vol. 40, no 3, 1997 (p. 465-492).

. O Poder Legislativo no Presidencialismo de Coalizão. Belo Horizonte:

Editora UFMG/Rio de Janeiro: IUPERJ, 2003 (p. 58-110). 
Instituições eleitorais e desempenho do presidencialismo no Brasil. Dados vol. $42 \mathrm{n}^{\circ}, 1999$.

SOUZA, Celina. Políticas Públicas: uma revisão da literatura. Sociologias, Porto Alegre, ano 8, n 16, jul/dez 2006 (p. 20-45).

SUGHART, Matthew Soberg; VALDINI, Melody Ellis e SUOMINEN, Kati. . Looking for Locals: Voter Information Demands and Personal Vote-Earning Attributes of Legislators under Proportional Representation. American Journal of Political Science, vol. 49, n 2, abril, 2005 (p. 437-449).

TAVARES DE ALMEIDA, Maria Hermínia. Negociando a Reforma: A Privatização de Empresas Públicas no Brasil. Revista Dados, Dados vol.42 n.3 Rio de Janeiro 1999.

TAYLOR, Michelle M. e DIAZ, Christophe . Who Gets Legislation Passed in a Marginal Legislature, How, and What Types of Legislation Is It? A Study of the Honduran Congress. Comparative Political Studies, no 32, 1999 (p. 589-625).

VOGEL, Luiz Henrique. A historicidade do Direito do Trabalho: a Constituição de 1988 no contexto da flexibilização das relações trabalhistas. In: José Cordeiro de Araújo (Org.). Ensaios sobre impactos da Constituição Federal de 1988 na sociedade brasileira. 1ed.Brasília: Centro de Documentação e Informação da Câmara dos Deputados, 2008, v. 1, (p. 343-363).

- Negociar Direitos? Legislação trabalhista e reforma neoliberal no governo FHC (1995-2002). Tese de Doutorado apresentada no Instituto de Estudos Sociais e Políticos (IESP-UERJ), 2010.

WILSON, James Q. The politics of regulation. In J. W. McKie (ed.), Social responsibility and the business predicament, Washington, D.C., The Brookings Institution, 1974.

YIN, Robert K. Estudo de caso: planejamento e métodos. 5 ed. Porto Alegre: Bookman, 2015. 
